\title{
Growth and survival of eleven planted tree species on a reclaimed surface mine in West Virginia
}

Paul Emerson

West Virginia University

Follow this and additional works at: https://researchrepository.wvu.edu/etd

\section{Recommended Citation}

Emerson, Paul, "Growth and survival of eleven planted tree species on a reclaimed surface mine in West Virginia" (2008). Graduate Theses, Dissertations, and Problem Reports. 2629.

https://researchrepository.wvu.edu/etd/2629

This Thesis is protected by copyright and/or related rights. It has been brought to you by the The Research Repository @ WVU with permission from the rights-holder(s). You are free to use this Thesis in any way that is permitted by the copyright and related rights legislation that applies to your use. For other uses you must obtain permission from the rights-holder(s) directly, unless additional rights are indicated by a Creative Commons license in the record and/ or on the work itself. This Thesis has been accepted for inclusion in WVU Graduate Theses, Dissertations, and Problem Reports collection by an authorized administrator of The Research Repository @ WVU. For more information, please contact researchrepository@mail.wvu.edu. 
Growth and Survival of Eleven Planted Tree Species on a Reclaimed Surface Mine in West Virginia

Paul Emerson

Thesis submitted to College of Agriculture, Forestry, and Consumer Sciences at West Virginia University in partial fulfillment for the requirements for the degree of

Master of Science

In

Plant and Soil Sciences

Thesis Committee:

Jeff Skousen, Chair

Eugenia Pena

Kathryn B. Piatek

Plant and Soil Sciences

Morgantown, WV 2008

Key Words: strip mine reforestation, compaction, gray unweathered sandstone, volume, survival. 


\section{Abstract \\ Growth and Survival of Eleven Planted Tree Species on a Reclaimed Surface Mine in West Virginina}

\section{Paul C. Emerson}

Commercial forestry as a post-mining land use in West Virginia requires an average of 1.2-m or more of weathered brown sandstone and topsoil on the spoil surface after regrading to the final land topography. Commercially valuable hardwood trees are to be planted in this substrate, and survival and growth of these trees must be monitored over a 12-year bonding period. Success of the commercial hardwood planting is based on the growth of white pine (Pinus strobus L.), which must achieve greater than 0.45 meters of average growth per year. At the Catenary surface mine in 2005, three, 2.8-ha plots were constructed: 1) 1.5-m of weathered brown sandstone, 2) 1.2-m of weathered brown sandstone, and 3) 1.5-m of unweathered gray sandstone. Half of each 2.8-ha plot was compacted, where dozer tracks completely covered the surface, while the other half had only one-pass from a dozer. In March 2005, eleven species of trees were planted into these plots. The objective of this research was to evaluate soil characteristics important to trees on these areas and to determine survival, volume, and percent change in height and diameter of each tree species. After one growing season, $91 \%$ of tree species survived on the $1.5-\mathrm{m}$ brown sandstone, $87 \%$ on $1.2-\mathrm{m}$ brown sandstone, and $98 \%$ on 1.5-m gray sandstone. On the non-compacted sides of each treatment, survival was $>99 \%$ across all species, whereas the compacted areas had $88 \%$ survival. Tree survival after three years had decreased to $67 \%$ on 1.5 -m brown sandstone, $82 \%$ on $1.2-\mathrm{m}$ brown sandstone, and $86 \%$ on 1.5 -m gray sandstone. On the non-compacted areas, $78 \%$ survived while $79 \%$ survived across all compacted plots. Highest survival rate across all 
treatments was black locust at $100 \%$, and lowest with Tulip poplar and White pine at $65 \%$ survival. Diameter and height were measured for trees and a volume was calculated by basal area (diameter squared) times height $\left(\mathrm{D}^{2} \mathrm{H}\right)$. Volume was greatest for Black locust with $792 \mathrm{~cm}^{3}$ and lowest for White pine at $36.1 \mathrm{~cm}^{3}$. Gray sandstone had the lowest volume across all species in all three plots with an average of $44.3 \mathrm{~cm}^{3}$ while $1.2-$ $\mathrm{m}$ brown sandstone had the greatest volume with $272 \mathrm{~cm}^{3}$. Percent height increase was greater on the brown sandstone treatment (86\%) as compared to the gray sandstone treatment $(17 \%)$. This trend continued with percent diameter increase which was $165 \%$ for brown sandstone and $62 \%$ for gray sandstone. Samples from all treatment plots showed the $\mathrm{pH}$ of the gray sandstone has continued to increase from an average of 7.9 after the first year to its highest level of 8.4 after the third year, while $1.5-\mathrm{m}$ brown sandstone had an average $\mathrm{pH}$ of 5.5 and $1.2-\mathrm{m}$ brown sandstone had an average $\mathrm{pH}$ of 4.5. Percent fines reached its highest proportion in the third year on both brown sandstone plots, while percent fines decreased on the gray sandstone plot between the first and second year (38\% to $30 \%$ ), but increased slightly to $33 \%$ by the third year.

In a fertility-leaching study, two leaching methods were used to compare brown and gray sandstone samples. These samples were repeatedly leached with Morgan's extract to examine concentrations of $\mathrm{Mg}, \mathrm{Ca}, \mathrm{P}$, and $\mathrm{K}$ through four leaching events. Two sieve sizes were also used to separate the sands from the clay and silt size particles. Comparison of extraction methods showed significant differences in $\mathrm{Ca}, \mathrm{K}$, and $\mathrm{P}$. There were no significant differences for any element between substrates (brown and gray sandstone) or sieve size.

Key Words: strip mine reforestation, compaction, gray unweathered sandstone, survival, volume. 
Table of Contents: $\quad$ Page

Chapter 1. Introduction and Objectives....................1

Chapter 2. Literature Review.............................5

Past Research.................................................5

Pre-SMRCA vs. Post-SMCRA......................6

Herbaceous Competition..........................7

Soil Physical and Chemical Characteristics...........8

Compaction.....................................9

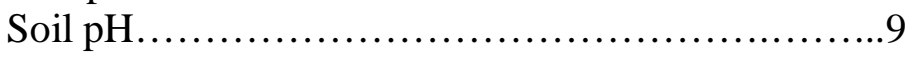

Electrical Conductivity.........................10

Chapter 3. Survival, volume, and percent change

Introduction......................................11

Materials and Methods

Experimental Design......................13

Tree Sampling Methods....................14

Tree Volume ..............................16

Percent Change...........................16

Ground Cover Characterization Methods....16

Statistics................................17

Results and Discussion

Volume and Percent change................17

Volume and Percent change by substrate... 50

Survival..................................54

Conclusions............................... 57

Chapter 4. Soil Physical and Chemical Properties Important to

Tree Growth and Survival

Introduction...................................59

Materials and Methods

Soil Sample Collection....................63

Soil Analysis Methods

Percent Fines and Percent

Sandstone..................63

Chemical Analysis..................64

Soil Fertility Experiment..................64

Results and Discussion .........................66

Conclusions

Soil physical and chemical properties........75

Soil Fertility...........................75

Chapter 5. Literature Cited.......................... 77 
Acknowledgments

I would like to first thank my committee of Dr. Pena, Dr. Piatek, and Dr. Skousen for their guidance throughout this process. I would especially like to thank Dr. Skousen who not only encouraged me to pursue a post-graduate degree, but also took personal interest in me and my future. I would like to thank my parents who have been nothing but supportive of my decisions and have made me into the individual that I am today. A special thanks also goes to Joan Wright for her countless hours of running samples and help around the laboratory as well as to Dr. Desta for his help with running statistics and Dr. Thompson for helping with formatting. Thank you to Magnum Coal and their employees who helped in the implementation of this study, specifically John McHale, Gina Bays, and Mitch Kalos. Thanks also go to the West Virginia DEP for their role in this study, especially Scott Eggerud for his part in the planning and continuance of this study. 
Table 1. Number, percentages, and species of trees planted in 2005 at Catenary's Samples Mine in Kanawha County, West Virginia.

Table 2. Species and rates of ground cover hydroseeded at Catenary's Samples Mine in Kanawha County, West Virginia.

Table 3. Number of each tree species measured on each treatment at Catenary Coal in 2007.

Table 4. Percent height and diameter increase of 11 planted species of trees across all treatments after three growing seasons at Catenary Coal Mine in Kanawha County, West Virginia.

Table 5. Volume $\left(\mathrm{HD}^{2}\right)\left(\mathrm{cm}^{3}\right)$ of 11 planted species of trees across all treatments after three growing seasons at Catenary Coal Mine in Kanawha County, West Virginia.

Table 6. Degrees of freedom, sum of squares, F value, and probabilities of survival and growth of 11 planted species at Catenary Coal, Kanawha County, West Virginia ...52

Table 7. Average values and significant differences for survival and volume of 11 planted species through three growing seasons at Catenary Coal, Kanawha County, West Virginia...53

Table 8. Percent survival of 11 planted species of tree on three soil mediums and two compaction treatments after three years at Catenary's Mine in Kanawha County, West Virginia.

Table 9. Degrees of freedom, sum of squares, $F$ value, and probabilities of select elements at Catenary Coal, Kanawha County, West Virginia

Table 10. Average values and significant differences for elements analyzed from samples at Catenary Coal, Kanawha County, West Virginia 
Table 11. 2005 to 2007 soil properties on three soil medium types under two compaction treatments at Catenary's Samples Mine in Kanawha County, West Virginia.............68

Table 12. Degrees of freedom, sum of squares, $\mathbf{F}$ values, and probabilities of four elements analyzed in fertility

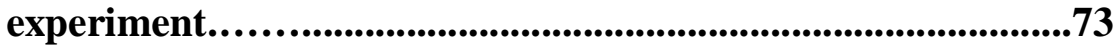

Table 13. Average values of $\mathrm{Mg}, \mathrm{Ca}, \mathrm{K}$, and $\mathrm{P}$ from brown and gray sandstone leached by two extraction methods............74 
Figure 1A. Average volume of Black locust across all treatments after three growing season at Catenary Coal Mine, Kanawha County, West Virginia

Figure 1B. Average survival of Black locust across all Treatments after three growing season at Catenary Coal Mine, Kanawha County, West Virginia.

Figure 1C. Average height, diameter, and percent increase of Black locust across all treatments after three growing seasons at Catenary Coal Mine, Kanawha County, West Virginia.

Figure 2A. Average volume of White pine across all Treatments after two growing season at Catenary Coal Mine, Kanawha County, West Virginia.

Figure 2B. Average volume of White pine across all Treatments after two growing season at Catenary Coal Mine, Kanawha County, West Virginia. 25

Figure 2C. Average height, diameter, and percent increase of White pine across all treatments after two growing seasons at Catenary Coal Mine, Kanawha County, West Virginia .26

Figure 3A. Average volume of Black cherry across all treatments after three growing season at Catenary Coal Mine, Kanawha County, West Virginia. .28

Figure 3B. Average survival of Black cherry across all treatments after three growing season at Catenary Coal Mine, Kanawha County, West Virginia .28

Figure 3C. Average height, diameter, and percent increase of Black cherry across all treatments after three growing seasons at Catenary Coal Mine, Kanawha County, West Virginia

Figure 4A. Average volume of Red oak across all treatments after three growing season at Catenary Coal Mine, Kanawha County, West Virginia. 
Figure 4B. Average survival of Red oak across all treatments after three growing season at Catenary Coal Mine, Kanawha County, West Virginia.

Figure 4C. Average height, diameter, and percent increase of Red oak across all treatments after three growing seasons at Catenary Coal Mine, Kanawha County, West Virginia.

Figure 5A. Average volume of Chestnut oak across all treatments after three growing season at Catenary Coal Mine, Kanawha County, West Virginia.

Figure 5B. Average survival of Chestnut oak across all treatments after three growing season at Catenary Coal Mine, Kanawha County, West Virginia...

Figure 5C. Average height, diameter, and percent increase of Chestnut oak across all treatments after three growing seasons at Catenary Coal Mine, Kanawha County, West Virginia.

Figure 6A. Average volume of White oak across all treatments after three growing season at Catenary Coal Mine, Kanawha County, West Virginia...

Figure 6B. Average survival of White oak across all treatments after three growing season at Catenary Coal Mine, Kanawha County, West Virginia.

Figure 6C. Average height, diameter, and percent increase of White oak across all treatments after three growing seasons at Catenary Coal Mine, Kanawha County, West Virginia.

Figure 7A. Average volume of Dogwood across all treatments after three growing season at Catenary Coal Mine, Kanawha County, West Virginia.

Figure 7B. Average survival of Dogwood across all treatments after three growing season at Catenary Coal Mine, Kanawha County, West Virginia. 
Figure 7C. Average height, diameter, and percent increase of Dogwood across all treatments after three growing seasons at Catenary Coal Mine, Kanawha County, West Virginia.

Figure 8A. Average volume of Redbud across all treatments after three growing season at Catenary Coal Mine, Kanawha County, West Virginia.

Figure 8B. Average survival of Redbud across all treatments after three growing season at Catenary Coal Mine, Kanawha County, West Virginia.

Figure 8C. Average height, diameter, and percent increase of Redbud across all treatments after three growing seasons at Catenary Coal Mine, Kanawha County, West Virginia.

Figure 9A. Average volume of Sugar maple across all treatments after three growing season at Catenary Coal Mine, Kanawha County, West Virginia.

Figure 9B. Average survival of Sugar maple across all treatments after three growing season at Catenary Coal Mine, Kanawha County, West Virginia.

Figure 9C. Average height, diameter, and percent increase of Sugar maple across all treatments after three growing seasons at Catenary Coal Mine, Kanawha County, West Virginia

Figure 10A. Average volume of Tulip poplar across all treatments after three growing season at Catenary Coal Mine, Kanawha County, West Virginia.

Figure 10B. Average survival of Tulip poplar across all treatments after three growing season at Catenary Coal Mine, Kanawha County, West Virginia.

Figure 10C. Average height, diameter, and percent increase of Tulip poplar across all treatments after three growing seasons at Catenary Coal Mine, Kanawha County, West Virginia. 
Figure 11A. Average volume of White ash across all treatments after three growing season at Catenary Coal Mine, Kanawha County, West Virginia............48

Figure 11B. Average survival of White ash across all treatments after three growing season at Catenary Coal Mine, Kanawha County, West Virginia............48

Figure 11C. Average height, diameter, and percent increase of White ash across all treatments after three growing seasons at Catenary Coal Mine, Kanawha County, West Virginia.....................................49

Figure 12. Volume of eleven planted species across all treatments after three growing season at Catenary Coal, Kanawha County, West Virginia...................54

Figure 13. Percent survival of all eleven species on compact vs. non-compact areas after three growing seasons at Catenary Coal Mine, Kanawha County, West Virginia.............................................57

Figure 14a. Backfilling and end dumping by trucks...........60

Figure 14b. "Topping off" piles after backfill with one or two passes from a bulldozer ...........................60

Figure 15. Soil pH across all treatments through three growing seasons at Catenary Coal in Kanawha County, West Virginia.

Figure 16. Phosphorus concentration across all treatments during three growing seasons at Catenary Coal, Kanawha County, West Virginia

Figure 17. Concentration of $\mathrm{Al}$ across all treatments after three growing seasons at Catenary Coal, Kanawha County, West Virginia

Figure 18. Concentration of $\mathrm{Mg}, \mathrm{Ca}, \mathrm{K}$, and $\mathrm{P}$ over four extraction rounds across both extraction methods...76 


\section{Chapter 1.}

\section{Introduction and Objectives:}

Coal was first discovered in West Virginia in 1742 by John Peter Salley in what is now Boone County, and nearly a century later, in 1834, the first commercial mine started (West Virginia Office of Miners' Health, Safety and Training, 2007). While some reclamation was being practiced, a majority of land was being left in an unreclaimed state after mining. It wasn't until 1939, when West Virginia passed the nation's first surface mine reclamation law, that coal companies started planting grasses, trees, or other ground covers in an attempt to lessen the environmental impacts of surface mining (Starnes and Gasper, 1995).

In 1945, legislation was passed that required coal companies to reclaim mined land to the land owner's preference, including grading of agricultural areas and/or the planting of trees, shrubs, grasses, and legumes (Acts of West Virginia Legislature, 1945). There were some early surface mines that used a forestry reclamation approach that now have decades-old forests which have recently been reaching maturity (Ashby, 1991).

West Virginia still has approximately 53 billion tons of minable coal left, which underlies a surface area of approximately 2 million ha (5 million ac) ( West Virginia Office of Miners' Health, Safety and Training, 2007). The forestry reclamation approach is of particular significance to West Virginia considering that the majority of this potentially mineable land has commercial forests growing on it (Plass and Powell, 1988). As the acreage of disturbed land continues to increase, people have become interested in reclaiming disturbed areas back into the productive forests that once grew on them. Doing so requires the consideration of many factors during initial reclamation including 
substrate type and depth, compaction of soil medium, ground cover type and density, and tree species selection (Torbert and Burger, 2000; Torbert et al., 1988, 1990; Vogel, 1981). Consideration of these factors while reclaiming and planting could lead to a quicker economic return from tree harvesting.

On August 3, 1977, Public Law 95-87, or the Surface Mining Control and Reclamation Act (SMCRA), was passed. This act was intended to enhance human safety, control erosion, improve water quality, and return the land to its approximate original contour (AOC). While it accomplished most of the goals it was set forth to do, it also created landscapes which were unproductive for forestland (Burger, 1999). As a result of this and of the movement towards hay and pasture land, reforestation on surface mined lands decreased dramatically (Ashby, 1991).

An example of a practice emphasized by SMCRA which has negative effects on tree growth is soil compaction. Mine operators commonly compact the surface with large equipment and grade the surface smooth creating a very dense substrate. This process is intended to stabilize the soil and help reduce erosion. However, some research has shown it can actually increase erosion due to slowed infiltration rates which increase surface runoff (Hatchell et al., 1970). On forestry sites, these over-compacted surfaces also create a poor growing medium which inhibits water infiltration, root growth, and the ability of a soil to drain once it becomes saturated (Omi, 1986). All of these compaction effects negatively impact tree survival and growth (Ashby, 1987; Ashby et al., 1984; Byrnes et al., 1980).

Heavy ground cover is also commonly used to control runoff and help with water quality issues. These heavy ground covers can be made up of many non-native and exotic 
species of grass, legume, forage, and shrub including tall fescue (Festuca arundinacea Schreb), Sericea lespedeza (Lespedeza cuneata) and clovers (Trifolium spp.). These species can fiercely compete with native grasses and trees which further prolong natural succession, even if the trees are planted concurrently with the grasses (Ashby, 1987). In 1999, Boyce commented that SMCRA "pitted quick ground cover and water quality against reforestation, water quality prevailed."

With SMCRA, laws and regulations promoted seeding reclaimed areas with grasses and legumes, which produced a quick economic return to the land owner through livestock grazing or sale of hay. However, good maintenance practices are required to keep these areas productive. When these areas go unmanaged, slowly pioneer tree species will invade as natural forest succession starts to take place. Gradually these areas move through many stages of succession that can take many decades to over a century before a forest of commercially valuable timber will dominate once again. Without the planning and consideration of many site specific factors, natural forest succession would take several hundred years for a forest of mid- to late-successional trees to dominate the forest (Burger and Zipper, 2002)

Currently, coal operators choose the rock overburden to be placed on the surface. Regulations require that the physical and chemical properties of the selected overburden be suitable for long-term plant growth which must have a self sustaining plant community and promote site stabilization, which is evaluated five years after mining. A certain degree of control can be exercised when trying to get the correct chemical properties for a growing medium. For example, shale has been shown to be a poor growing medium for trees due to its high alkalinity, but is acceptable when growing 
grasses and legumes. While the overburden selected can be good for hay/pasture land and wildlife habitat, it may not be good for forestry reclamation (Torbert, 1995). This adds to the dilemma of converting old hay/pasture land back into commercial forest. Coal operators also must select an overburden which has enough quantity to be spread over the desired area and to the desired depth. Taking these factors (compaction, competition, substrate, etc) into consideration the mine operator should be able to decrease the amount of time needed to return mined areas back into a productive landscape.

The objectives of this study were to:

1) Evaluate tree volume, percent height and diameter change, and survival on compacted vs. non-compacted areas and areas with brown weathered sandstone vs. gray unweathered sandstone at the surface;

2) Evaluate soil chemical and physical properties of these substrates. 


\section{Chapter 2.}

\section{Literature Review}

By 1962, about 28,329 ha (70,000 ac) of land in the United States had been disturbed by surface mining, with very little of it being reclaimed to forest land (Brown, 1962). While some tree planting was occurring in the 1920's and 30's, it was not applied to large scale surface mines until the 1940's (Mickalitis and Kutz, 1949; Potter et al., 1955). In 1945 legislation was passed in West Virginia requiring coal companies to reclaim the land back to the way the land owner wanted it, including grading agricultural areas and/or planting trees, shrubs, grasses, and legumes. About a decade later interest began to emerge in the planting of hardwoods. However, with the passage of SMCRA in 1977, reclamation was focused mainly on water quality and erosion control. Due to SMCRA, reclamation with trees declined and heavy seeding of grasses and legumes became the dominant reclamation approach (Holl et al., 2001).

\section{Past Research:}

Early experiments in West Virginia included a survey of 10 plantings which made recommendations for specific plant species. Of the eight species listed, half were pines (Red pine (Pinus resinosa), Pitch pine (Pinus rigida), Jack pine (Pinus banksiana), and Virginia pine (Pinus virginiana), while the other half were native hardwoods (Black locust (Robinia pseudoacacia), tulip poplar (Liriodendron tulipifera), red maple (Acer rubrum), and sycamore (Acer pseudoplatanus)) (Potter et al., 1955).

Tyner et al. (1948) concluded in this study that compacted surface layers down to $45.5 \mathrm{~cm}$ (18 in) created survival problems for tree seedlings, some grasses, and certain legumes during dry periods. However, tap-rooted legumes like alfalfa, sweet clover, and 
birdsfoot trefoil, were able to penetrate the compacted layer and therefore were not as affected by drought (Tyner et al., 1948).

In more recent decades studies at the Powell River Project, located in southwestern Virginia, have involved substrate selection, minesoil morphology, and proper reclamation approaches for forestry reclamation on mined land (Torbert et al., 1985; Burger et al., 2005a).

\section{Pre-SMCRA vs. Post-SMCRA}

When the Surface Mining Control and Reclamation Act (SMCRA) was passed in 1977, it helped improve mining reclamation in many facets including erosion control, return of land to its approximate original contour (AOC), water quality, and soil $\mathrm{pH}$ (Davidson et al., 1984). This approach of regrading to AOC, compaction of the surface, and seeding a thick ground cover was intended to control erosion and provide a quick sustainable land use. However, compaction and thick ground cover have been found to be counter-productive in producing hardwood forests (Ashby, 1991; Chaney et al., 1995; Rodrigue and Burger, 2004; Torbert, 1995).

Before the Surface Mining Control and Reclamation Act (SMCRA), the use of the "shoot and shove" method dominated contour surface mining. This method of mining would simply blast (shoot) the overburden off the coal seem to be mined. The blasted material on the coal was then pushed (shoved) to expose the coal seam. After the coal was removed, a flat bench was often left. This left the land with exposed highwalls and varying depths of rocky overburden that had been blasted and pushed over the side of the hill (Daniels and Zipper, 1998; Haering et al., 2004). This blasted material left on the surface was in reasonably good condition for tree recolonization and growth because the 
substrate was left uncompacted and little, if any, seeding with herbaceous competition for the control of erosion was done afterwards creating much less competition for trees (Skousen et al., 2006).

\section{Herbaceous Competition}

Next to physical and chemical properties, the greatest hindrance to successful tree establishment is competition from herbaceous vegetation (Torbert and Burger, 2000). According to SMCRA, coal operators must establish "a diverse, effective, and permanent vegetative cover of the same seasonal variety native to the area of land to be affected and capable of self-regeneration and plant succession at least equal in extent of cover to the natural vegetation of the area..." The cover must also be "capable of stabilizing the soil surface from erosion" (Section 816.111 of SMCRA). To comply with these standards, coal operators generally establish a dense ground cover that grows quickly. This ground cover is generally composed of aggressive perennial grasses hydroseeded at high rates with fertilizers and mulch. Often this ground cover has consisted of Kentucky-31 tall fescue (Festuca arundinacea Schreb), red clover (Trifolium pratense L.), Sericea Lespedeza (Lespedeza cuneata), Birdsfoot Trefoil (Lotus corniculatus L.) and other species, all of which are non-native, very dense and competitive with tree seedlings. Ashby (1997) stated that tree and shrub seedlings native to any site will be negatively affected by ground cover and other competition. Research has suggested that some of these aggressive grasses and legumes have hindered site reclamation in the long run due to competition (Burger and Torbert, 1990; Holl, 2002; Torbert and Burger, 2000). Research by Torbert and Burger (2000) showed less-competitive species to be a better option when seeding ground cover. Redtop (Agrostis gigantean), Birdsfoot Trefoil 
as well as other annual grasses, perennial grasses, and legumes have been found to control erosion effectively for the first year, while at the same time allowing for better establishment of native tree species (Holl, 2002).

Other problems which have arisen from the competition of grasses are that they can grow much taller than the young seedlings in the early stages of development and smother the seedlings when the tall grasses die back in the winter. In addition, a heavy groundcover also provides cover for small mammals which can feed on the bark and girdle trees (Torbert et al., 2000). By reducing the competition for available nutrients, water and light, tree seedlings will have a better chance of establishing themselves in the mine soil.

\section{Soil Physical and Chemical Characteristics}

With larger equipment and advancements in mining technology since the passage of SMCRA, surface mining operators can now remove much greater volumes of overburden to reach the coal. These greater depths to obtain coal often extend well below the oxidized strata (weathered brown sandstone) and into the unoxidized strata (gray unweathered sandstone). The gray unweathered sandstone usually comes from deep within the geologic column where it has not undergone any weathering or oxidation reactions. When placed on the surface, the unweathered material can undergo rapid changes in physical and chemical properties in a relatively short time span (Haering et al., 1993). With the rapid weathering of these sandstones, a mine soil profile can start to develop in as little as three years (Sencindiver and Ammons, 2000).

With time, previously broken up rock material begins to weather and form into soil-like material. Physical and chemical properties such as bulk density, percent fines, 
percent sandstone, and nutrient concentrations change over time as these soils weather, and as a consequence produce a substrate where plants can thrive.

\section{Compaction}

Compaction of substrate is a critical attribute when considering growth of trees. When grading (placement and smoothing of the surface) occurs, it is common practice for large machinery to be used which leads to compaction of the substrate, especially if the equipment is large rubber wheeled vehicles. Ripping or less intensive grading will leave the soil loosened and rougher which will enhance moisture retention and root penetration, and the surface roughness will deter erosion (Phillips, 2006). The magnitude of grading or the amount of ripping will have a large influence on physical characteristics such as bulk density. Nearly every eastern state with coal mining has conducted research showing grading as a variable of concern. These studies show that intensive grading generally results in reduced growth of trees planted on strip-mined areas (Erhart, 1984; Siegel-Issem et al., 2005; Zeleznik and Skousen, 1996).

\section{Soil pH}

The $\mathrm{pH}$ of mine soils is largely determined by their parent material and weathering conditions. Soil materials made of weathered brown sandstone tend to be more acidic (3.5-4.5) while unweathered gray sandstone materials, depending upon acid or base generating constituents, are generally much more alkaline (7.9-8.4) (Haering et al., 2004). Soil $\mathrm{pH}$ can also vary greatly even within a few meters. For instance, it is not unusual to find extremely acidic $\mathrm{pH}$ values (3.5-4.4) close to moderately alkaline soils with a pH of 7.9-8.4 (Haering et al., 2004). This may be attributed to materials with high levels of carbonate and/or reactive pyrite that can change $\mathrm{pH}$ by several orders of 
magnitude upon weathering (Sobek et al., 2000). Due to this weathering of alkalinity and acidity producing reactions, the $\mathrm{pH}$ of the soil has also been known to fluctuate between years. If these carbonates or reactive pyrites are in high enough quantity, they can increase or decrease the $\mathrm{pH}$ of the minesoil.

\section{Electrical Conductivity}

Electrical conductivity indicates the concentration of ionized constituents in the extract and is the best measure of total salt content or salinity potential (Jurinak et al., 1987; Sobek et al., 2000). Soluble salts have been found to be an influential variable in the growth and survival of tree seedlings (Andrews et al., 1998; Davidson, 1984; McFee et al., 1981; Torbert et al., 1988). If EC is too high it can inhibit carbon dioxide and water uptake as well as inhibit enzymes associated with protein synthesis and $\mathrm{C}$ metabolism (Tiaz and Zeiger, 1991). Studies have found a decrease in site productivity with an increase in the soluble salt concentration (Andrews et al., 1998; Rodrigue and Burger, 2004; Torbert et al., 1988; Torbert et al., 1990). In one of these studies, Torbert et al. (1988) showed that texture played a significant role in the electrical conductivity of the mine soil. Their study showed that finely-textured soils whose parent material consisted of mainly shales and siltstones had much higher EC than more coarse sandstone overburdens. This finding was backed up by Rodrigue and Burger (2004), who also found that an increase in soluble salts concentrations had an adverse effect of site productivity. Soluble salt concentrations of $>1000-3000 \mu \mathrm{S} \mathrm{cm}^{-1}\left(>1-3 \mathrm{dS} \mathrm{m}^{-1}\right)$ were found to be unfavorable for plant growth and tree survival (Cummins et al., 1965; McFee et al., 1981). 


\section{Chapter 3.}

\section{Survival, volume, and percent change of eleven hardwood tree species on reclaimed land in West Virginia.}

\section{Introduction}

When large scale surface mining started in West Virginia in the early to mid 1900's, reclamation seldom occurred and when companies did some reclamation it usually involved tree planting. Some of these early mining techniques, such as the shoot and shove method, left the land in a condition suitable for tree growth. This occurred because operators simply blasted the overburden material and shoved it down slope which created an area that left largely weathered uncompacted materials on the surface with little to no herbaceous competition. Starting in the 1930's and 40's coal operators were required to start reclaiming the land. At first, some experiments were done to reclaim land back to forest by planting early succession species such as black locust and autumn olive (Skousen et al., 2006). A few hardwood species like black cherry and oak were planted, and some survived and grew well (Skousen et al., 1994). A few decades after this, laws and regulations were passed in the eastern United States that promoted seeding reclaimed areas with grasses and legumes, which produced a quick economic return to the land owner through livestock grazing or sale of hay. However, good maintenance practices were required to keep these areas productive. When these areas were unmanaged, pioneer tree species invaded and the area gradually moved through many stages of plant community succession that can take many decades to well over a century before a forest of commercially valuable timber will dominate. Due to compacted mine soils and herbaceous competition from grasses, tree growth and establishment were hindered and the process of forest succession was delayed. 
Natural forest succession takes place after major disturbances such as fire or landslides. In these cases there is usually a seed bank from which plants can grow, as well as stumps from which sprouts can initiate growth from established root systems. In mining reclamation this is usually not the case as there is no seed bank as well as no stumps with established root systems. To help succession progress more rapidly, early and late successional tree species are planted concurrently. This helps keep competing weeds at a minimum while allowing for natural encroachment from the surrounding forest or vegetation (Groninger et al., 2007).

More recent developments in reclamation include the return of land to approximate original contour (AOC). As a general rule, the post mining contours must be within 20 $30 \%$ of the original contours. Returning land to AOC can be a costly procedure for coal companies and some surface mining operations can seek variances from AOC to create a more gently sloping condition for other post-mining land uses. Currently companies with AOC variances are limited to either industrial uses or commercial forestry as post mining land uses.

Industrial post mining land uses include airports, high schools, prisons, golf courses, and other businesses that need flat land or rolling landscapes on which to build. Commercial forestry requires the planting and establishment of commercially valuable species and includes a 12-year bonding period where trees must achieve growth standards. White pine was chosen as an indicator species for growth success of all trees. This species must achieve four or more years of at least $0.5-\mathrm{m}$ of growth per year. Failure to meet such standards may require companies to pay large sums of money into a specially designated reclamation fund. When reclaiming mountaintop mining sites, 
revegetation is done soon after grading to control erosion. To achieve bond release within 12 years, it is important to plant trees early and to monitor their progress. Bond cannot be released before five years after tree planting and the White pine productivity standard must be met by the twelfth year after planting.

\section{Objectives}

Taking all the previously mentioned factors into consideration, the objectives of this study were to:

1) Evaluate tree volume, survival, and percent height and diameter change on areas that were compacted vs. non-compacted and with substrates composed of brown weathered sandstone vs. gray unweathered sandstone;

2) Evaluate soil chemical and physical properties of these substrates.

\section{Materials and Methods \\ Experimental Design}

Catenary Coal Company received approval from the West Virginia Division of Environmental Protection to conduct an Experimental Practice at the Samples Mine in Kanawha County, West Virginia. The Experimental Practice involves planting commercially valuable hardwood trees into unweathered gray sandstone and weathered brown sandstone. As part of the Experimental Practice, three demonstration plots composed of three soil medium types were also established. In January of 2005, three distinct 2.8-ha (7-ac) plots were established: the first had 1.5-m of weathered brown sandstone placed on the surface, the second had 1.2-m of weathered brown sandstone placed on the surface, and the third had 1.5-m of unweathered gray sandstone placed on 
the surface. The materials were hauled to the sites and end-dumped into piles from large 200-ton rock trucks. Each pile was dumped so that it was connected and abutted to surrounding piles. After placement, one-half of each plot was compacted (dozer tracks completely covering the surface), while the other half was uncompacted with only one or two passes with a dozer. The dozer knocked off the tops of the piles with only one pass for the uncompacted areas. For the compacted areas the dozer made several passes to smooth the surface and to cover the entire surface with dozer tracks. The substrate type (brown or gray), depth (1.2-m or 1.5-m) and compaction (compact or non-compact) define one treatment (i.e. 1.5-m brown sandstone compact is one treatment and 1.5-m brown sandstone non-compact is another treatment).

In March 2005, 11 different tree species were planted in a random fashion on these 2.8-ha (7-ac) plots (Table 1). Two years after completion of tree planting (Fall of 2007), the areas transplanted with trees were hydroseeded with the seeding rate shown in Table 2.

\section{Tree Sampling Methods}

In the spring of 2005, two, 2.7-m wide by 195-m long transects were established in an "X" pattern across each of the 2.8-ha (7-ac) plots. Any tree within the 2.7-m wide transect was identified by species, and measured for height and diameter. Tree stem diameter was measured approximately $25 \mathrm{~mm}$ from the ground. 
Table 1. Number, percentages, and species of trees planted in 2005 at Catenary's Samples Mine in Kanawha County, West Virginia.

\begin{tabular}{lccc}
\hline Species (Latin name) & Abbreviation & Total Planted & \% of planted \\
\hline & & & \\
Black Cherry (Prunus serotina) & BC & 4,500 & $3.0 \%$ \\
Black Locust (Robinia pseudoacacia) & BL & 5,500 & $3.7 \%$ \\
Chestnut Oak (Quercus prinus) & CNO & 11,500 & $7.7 \%$ \\
Dogwood (Cornus alternifolia) & DW & 5,500 & $3.7 \%$ \\
Red Bud (Cercis canadensis) & RB & 4,500 & $3.0 \%$ \\
Red Oak (Quercus rubra) & RO & 33,000 & $22 \%$ \\
Sugar Maple (Acer saccharum) & SM & 15,000 & $10 \%$ \\
Tulip Poplar (Liriodendron tulipifera) & TP & 15,000 & $10 \%$ \\
White Ash (Fraxinus americana) & WA & 24,750 & $16.5 \%$ \\
White Oak (Quercus alba) & WO & 26,250 & $17.5 \%$ \\
White Pine (Pinus strobus) & WP & 4,500 & $3 \%$ \\
& & & \\
Total & & 150,000 & $100 \%$ \\
\hline
\end{tabular}

Table 2. Species and rates of ground cover hydroseeded at Catenary's Samples Mine in Kanawha County, West Virginia.

\section{Rate of Application}

$\underline{\text { Species }}$

Red Top (Agrostis gigantea)

Perennial ryegrass (Lolium perenne)

Birdsfoot trefoil (Lotus corniculatus)

Total $\underline{\text { Rate }}$

$2.2 \mathrm{~kg} / \mathrm{ha}$

$2.2 \mathrm{~kg} / \mathrm{ha}$

$11.0 \mathrm{~kg} / \mathrm{ha}$

$15.4 \mathrm{~kg} / \mathrm{ha}$ 


\section{Tree volume}

There have been many linear regression techniques developed to predict total tree and component weights from easily measured tree dimensions. Since weight and volume are significantly correlated, most of these equations use height and diameter as the two variables of interest, and thus are the basic tree dimensions used for predicting stem volume. Volume is a product of basal area $\left(\right.$ diameter $\left.^{2}\right)$ multiplied by height. This equation was originally developed for mixed oak stands in southwest Wisconsin by Gevorkian and Scholtz in 1944. By squaring the diameter, the equation becomes a linear function for comparisons of volume increase between treatments. So, as $\mathrm{D}^{2} \mathrm{H}$ increases, volume increases linearly. If an actual biomass was desired, measurements of actual weights of a few trees are needed to develop the coefficients, but since this research is simply making treatment effect comparisons within the same species, a relative estimate is adequate. Researchers using the $\mathrm{D}^{2} \mathrm{H}$ for determining growth of young seedlings include Auch et al., 2004; Casselman et al., 2006; Howard and Newton, 1984; and Norby and O’Neill, 1991.

\section{Percent change}

To compare each species relative to each other, percent change in height and diameter was calculated from the equation: Percent $(x)$ change $=100 *((2007 x-$ $2005 x) / 2005 x)$

Where $\mathrm{x}$ is either height or diameter in 2005 or 2007.

\section{Ground Cover Characterization Methods}

Ground cover (percentage) was evaluated in $1 \mathrm{~m}^{2}$ quadrats. The 
quadrat was placed on five random locations within each treatment (one treatment is defined as $1.5-\mathrm{m}$ gray sandstone compact, 1.5 -m gray sandstone non-compact is another treatment) along the transects. Total herbaceous cover was estimated, and the three most dominant grass or legume species contributing to the total herbaceous cover were identified.

\section{Statistics}

Data for tree survival and volume were analyzed by a 2-way ANOVA to determine significant differences between geology (gray vs. brown, 1.5-m brown vs. 1.2$\mathrm{m}$ brown), and compaction treatments. Interactions (1.5-m gray sandstone non-compact) were also analyzed by ANOVA. This was done for each species. Species survival and volume data was also compared among species. Nutrients were compared using a 3-way ANOVA for geology, treatment, and year. Distribution of volume was not normally distributed with six extreme outliers. The volume data were also log transformed to attempt to normalize the data.

\section{Results and Discussion}

\section{Volume and percent change in height and diameter}

Only one significant difference was found for tree volume among tree species. Black locust outperformed all other species with $792.0 \mathrm{~cm}^{3}$. Though some other species appear to have significant differences, no others were found because the standard

deviation was high. The number of each species measured in each treatment can be seen in Table 3. 
Black locust out performed all other species (Figure 1A-1C) by having the highest percent height and diameter increase (266\% increase in height, $277 \%$ increase in diameter, Table 4) as well as the largest volume after three years $\left(792.0 \mathrm{~cm}^{3}\right)$ across all treatments (Table 5). This is no surprise as Black locust has repeatedly shown good growth and survival on minesoils (Ashby et al., 1985). 
Table 3. Number of each tree species measured on each treatment at Catenary Coal in 2007.

Treatments

\begin{tabular}{ccccccc}
$5 B^{1}$ & $5 B ~ C$ & $4 B ~ N C$ & $4 B ~ C$ & $5 G ~ N C$ & $5 G ~ C$ & Total \\
\hline
\end{tabular}

Black Cherry

Black Locust

Chestnut Oak

Dogwood

Redbud

Red Oak

Sugar Maple

Tulip Poplar

White Ash

White Oak

White Pine

3

$\begin{array}{lll}3 & 1 & 2\end{array}$

$\begin{array}{lll}5 & 5 & 6\end{array}$

$\begin{array}{lll}9 & 7 & 11\end{array}$

$\begin{array}{lll}6 & 3 & 6\end{array}$

$\begin{array}{lll}6 & 4 & 4\end{array}$

$16 \quad 16$

5

$6 \quad 6$

$9 \quad 12 \quad 16$

$\begin{array}{lll}7 & 12 & 20\end{array}$

Total

$7 \quad 6$

$112 \quad 77$

$\begin{array}{cc}2 & 2 \\ 6 & 1 \\ 1 & 6 \\ 6 & 3 \\ 4 & 6 \\ 21 & 12 \\ 14 & 9 \\ 5 & 1 \\ 6 & 19 \\ 20 & 12 \\ 7 & 6 \\ 86 & 77\end{array}$

$\begin{array}{cccc}2 & 7 & 1 & 16 \\ 1 & 1 & 5 & 23 \\ 6 & 5 & 1 & 39 \\ 3 & 3 & 3 & 24 \\ 6 & 2 & 8 & 30 \\ 12 & 16 & 19 & 100 \\ 9 & 8 & 8 & 51 \\ 1 & 11 & 9 & 38 \\ 19 & 11 & 9 & 76 \\ 12 & 16 & 9 & 76 \\ 6 & 6 & 5 & 37 \\ 77 & 79 & 79 & \\ \end{array}$

${ }^{1} 5 \mathrm{~B} \mathrm{NC}=1.5-\mathrm{m}$ brown sandstone non-compact

$5 \mathrm{~B} \mathrm{C}=1.5-\mathrm{m}$ brown sandstone compact

$4 \mathrm{~B} \mathrm{NC}=1.2-\mathrm{m}$ brown sandstone non-compact

4B $\mathrm{C}=1.2-\mathrm{m}$ brown sandstone compact

$5 \mathrm{G} \mathrm{NC}=1.5-\mathrm{m}$ gray sandstone non-compact

$5 \mathrm{G} \mathrm{C}=1.5-\mathrm{m}$ gray sandstone compact 
Table 4. Percent height and diameter increase of 11 planted species of trees across all treatments after three growing seasons at Catenary Coal Mine in Kanawha County, West Virginia.

\begin{tabular}{|c|c|c|c|c|c|c|c|}
\hline \multicolumn{8}{|c|}{ Treatments } \\
\hline Species & 5B-C & 5B-NC & 4B-C & 4B-NC & 5G-C & 5G-NC & Avg. \\
\hline \multicolumn{8}{|c|}{ 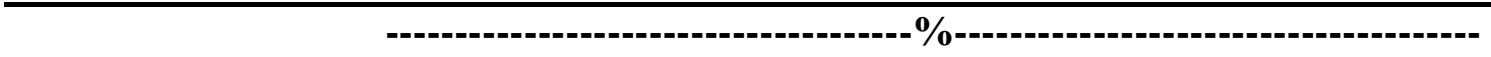 } \\
\hline \multicolumn{8}{|c|}{ ( } \\
\hline Black Cherry & $\mathbf{N A}^{\mathbf{1}}$ & 33 & 106 & 2 & 16 & 44 & 40 \\
\hline Black Locust & 389 & 397 & 249 & 415 & 79 & 66 & 266 \\
\hline Chestnut Oak & 97 & 63 & 57 & 23 & 16 & 16 & 45 \\
\hline Dogwood & 44 & 57 & 39 & 6 & -49 & -24 & 12 \\
\hline Redbud & 17 & 9 & 32 & -13 & -35 & 10 & 3 \\
\hline Red Oak & 65 & 57 & 63 & 47 & -8 & 11 & 38 \\
\hline Sugar Maple & 29 & 33 & 15 & -12 & $\mathbf{0}$ & 4 & 11 \\
\hline Tulip Poplar & 157 & 39 & 185 & 44 & 37 & 0 & 77 \\
\hline White Ash & 115 & 161 & 200 & 138 & 15 & 105 & 122 \\
\hline White Oak & 45 & 16 & 49 & 25 & 4 & 25 & 27 \\
\hline White Pine & 72 & 68 & 57 & 16 & 26 & 23 & 44 \\
\hline Avg. & 103 & 84 & 95 & 63 & 9 & 25 & 62 \\
\hline \multicolumn{8}{|l|}{ Diameter } \\
\hline Black Cherry & NA & 116 & 169 & 135 & 39 & 113 & 114 \\
\hline Black Locust & 456 & 298 & 373 & 377 & 51 & 109 & 277 \\
\hline Chestnut Oak & 225 & 148 & 122 & 87 & 71 & 14 & 110 \\
\hline Dogwood & 201 & 220 & 242 & 164 & 31 & 51 & 152 \\
\hline Redbud & 215 & 243 & 127 & 158 & -32 & 148 & 143 \\
\hline Red Oak & 165 & 151 & 194 & 166 & 40 & 82 & 133 \\
\hline Sugar Maple & 63 & 132 & 81 & 56 & 54 & 100 & 81 \\
\hline Tulip Poplar & 128 & 144 & 173 & 126 & 61 & 70 & 117 \\
\hline White Ash & 167 & 204 & 224 & 161 & 48 & 126 & 155 \\
\hline White Oak & 139 & 84 & 143 & 72 & 48 & 75 & 94 \\
\hline White Pine & 64 & 191 & -47 & 37 & 49 & 16 & 51 \\
\hline Avg. & 182 & 176 & 164 & 139 & 41 & 82 & 130 \\
\hline
\end{tabular}


Table 5. Volume $\left(\mathrm{HD}^{2}\right)\left(\mathrm{cm}^{3}\right)$ of 11 planted species of trees across all treatments after three growing seasons at Catenary Coal Mine in Kanawha County, West Virginia.

\begin{tabular}{|c|c|c|c|c|c|c|c|}
\hline \multicolumn{8}{|c|}{ Treatments } \\
\hline Species & 5B-C & 5B-NC & 4B-C & 4B-NC & 5G-C & 5G-NC & Avg. \\
\hline \multicolumn{8}{|c|}{ 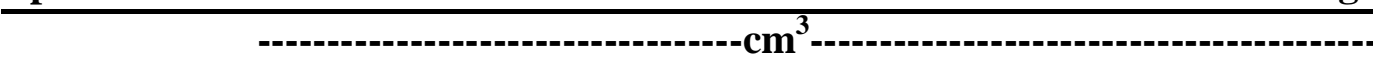 } \\
\hline Black Cherry & $\mathbf{N A}^{1}$ & 180.3 & 522.7 & 92.9 & 73.6 & 155.2 & 170.8 \\
\hline Black Locust & 213.4 & 1208.0 & 1294.2 & 1863.2 & 58.2 & 114.7 & 792.0 \\
\hline Chestnut Oak & 127.2 & 46.9 & 129.1 & 24.4 & 26.7 & 18.5 & 62.1 \\
\hline Dogwood & 156.2 & 286.1 & 208.6 & 157.2 & 10.7 & 19.0 & 139.6 \\
\hline Redbud & 185.0 & 69.3 & 124.4 & 100.3 & 6.4 & 83.9 & 94.9 \\
\hline Red Oak & 101.9 & 103.7 & 131.9 & 119.5 & 20.3 & 32.1 & 84.9 \\
\hline Sugar Maple & 53.9 & 89.6 & 44.1 & 16.2 & 19.1 & 36.4 & 43.2 \\
\hline Tulip Poplar & 160.9 & 100.6 & 590.9 & 52.3 & 88.2 & 58.5 & 175.2 \\
\hline White Ash & 173.5 & 108.6 & 204.2 & 102.9 & 22.5 & 33.4 & 107.5 \\
\hline White Oak & 79.1 & $\mathbf{5 0 . 0}$ & 108.2 & 44.7 & 28.0 & 38.0 & $\mathbf{5 8 . 0}$ \\
\hline White Pine & 32.3 & 85.7 & 34.2 & 27.4 & 24.3 & 10.3 & 35.7 \\
\hline Avg. & 128.3 & 211.7 & 308.4 & 236.4 & 34.4 & 54.6 & 162.3 \\
\hline
\end{tabular}

All Black cherry trees in the 5B-C plot were dead by 2007 


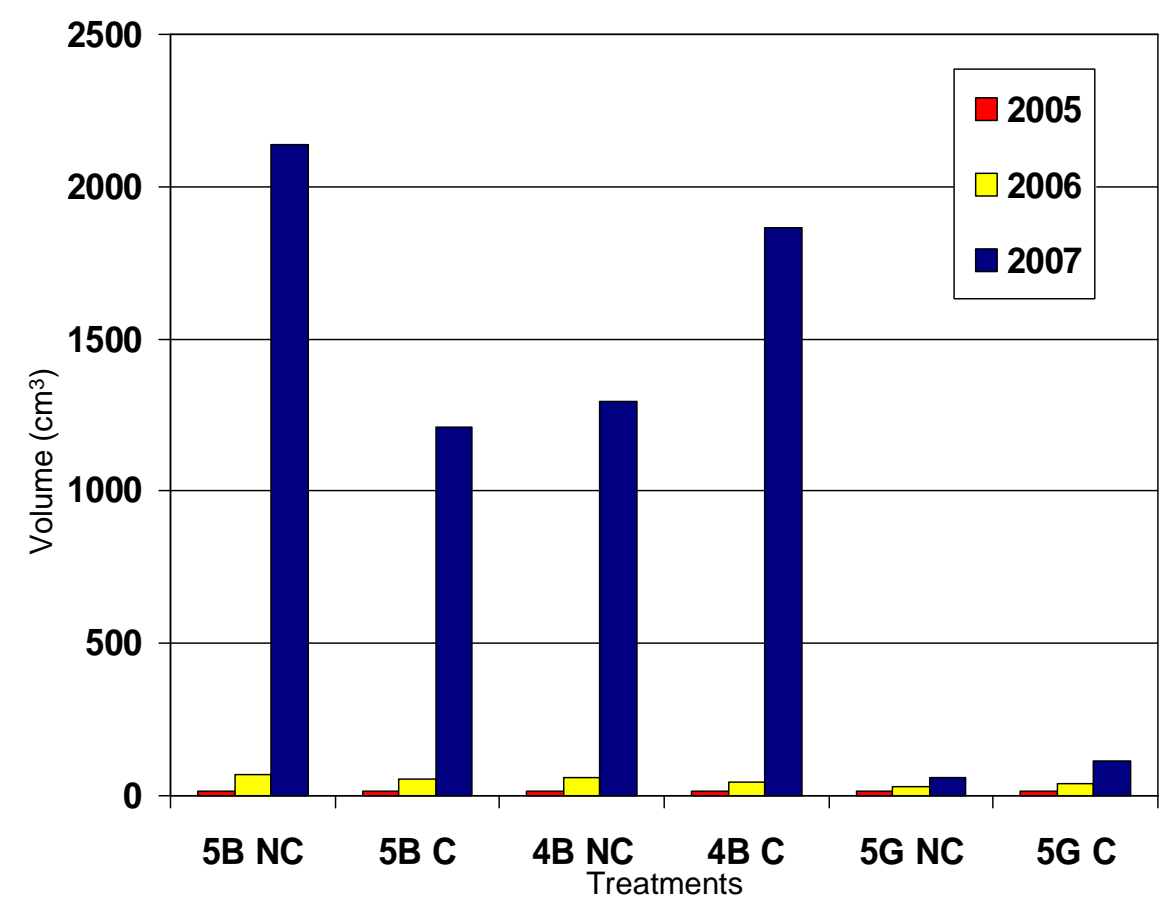

Figure 1A. Average volume of Black locust across all treatments after three growing season at Catenary Coal Mine, Kanawha County, West Virginia.

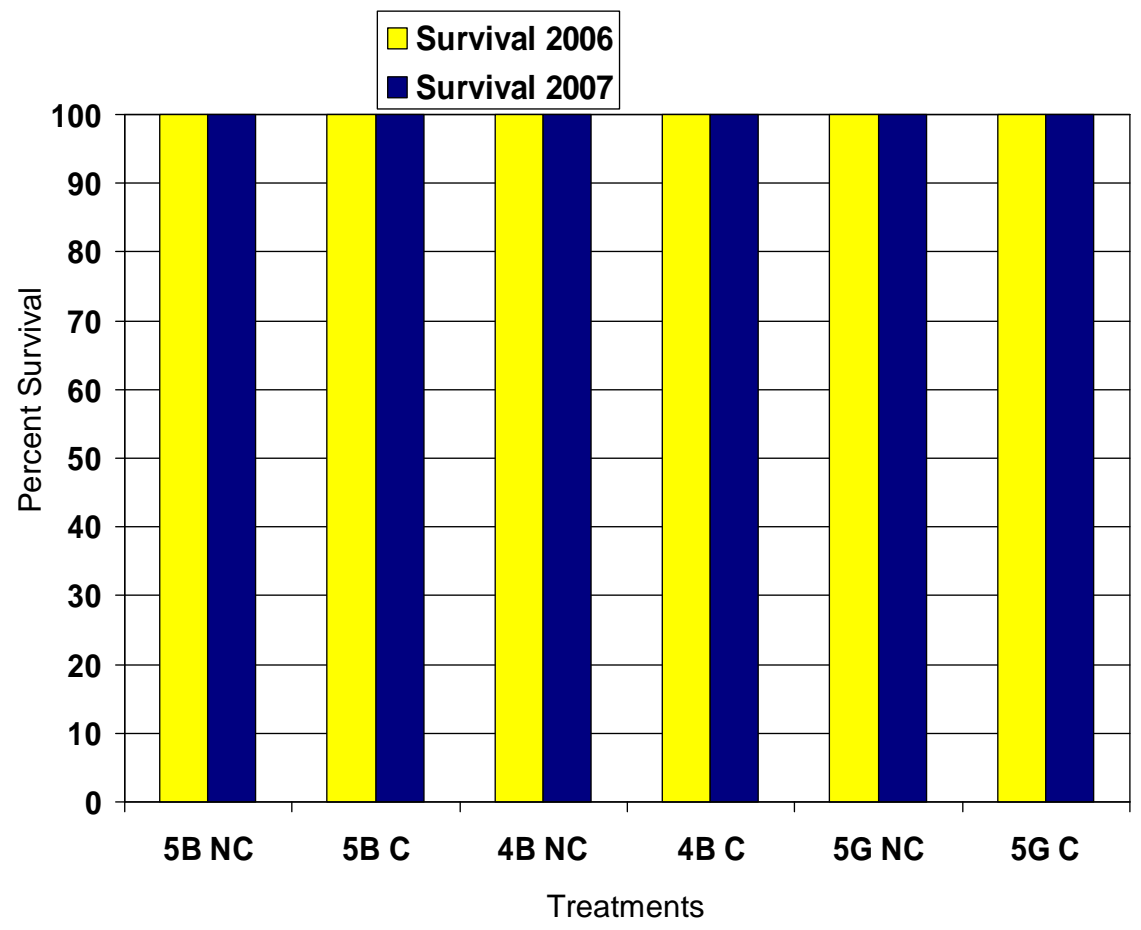

Figure 1B. Average survival of Black locust across all treatments after three growing seasons at Catenary Coal Mine, Kanawha County, West Virginia. 


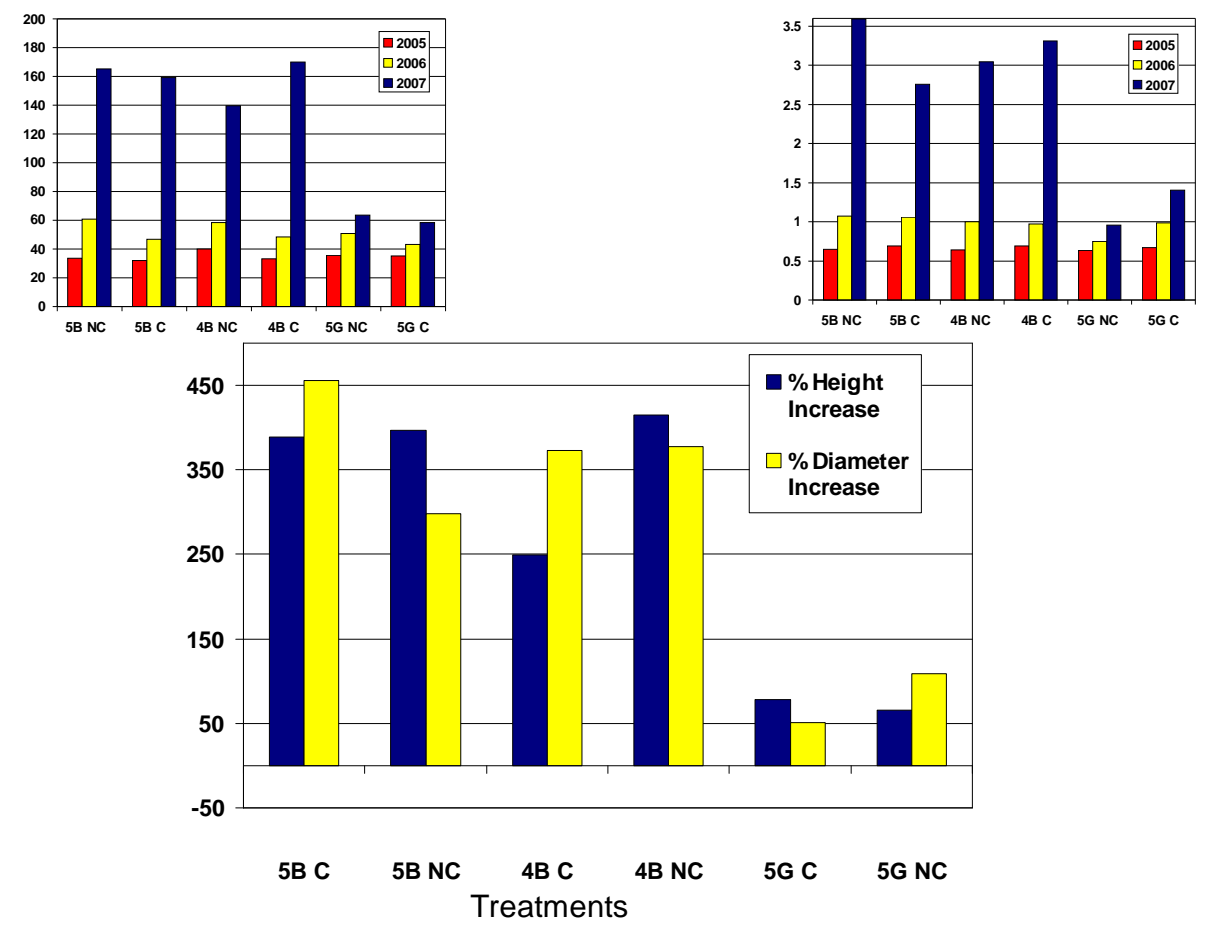

Figure 1C. Average height, diameter, and percent increase of Black locust across all treatments after three growing seasons at Catenary Coal Mine, Kanawha County, West Virginia. 
White pine had the lowest volume across all treatments and species with only 35.7 $\mathrm{cm}^{3}$, however, this species was only measured in 2006 and 2007 due to excessive mortality the first year (2005) (Figures 2A-2C). White pine also had the lowest amount of diameter increase of all species (51\%), but outperformed six species (Black cherry, Dogwood, Redbud, Red oak, Sugar maple, and White oak) in percent height increase. White pines generally do not do well during the initial few years of establishment, which is reflected by its low volume, survival, and percent diameter increase (Wendel and Smith, 1990; Lancaster and Leak, 1978; Hicks, 1998). However, White pine has been extensively planted on mine soils and has shown good growth and survival over longer spans of time. In some cases White pine can produce a merchantable stand of timber in 30 to 40 years (Balmer and Williston, 1983). White pine can grow in a wide variety of soils including those with igneous and sedimentary origin, as well as glaciated and unglaciated regions. 


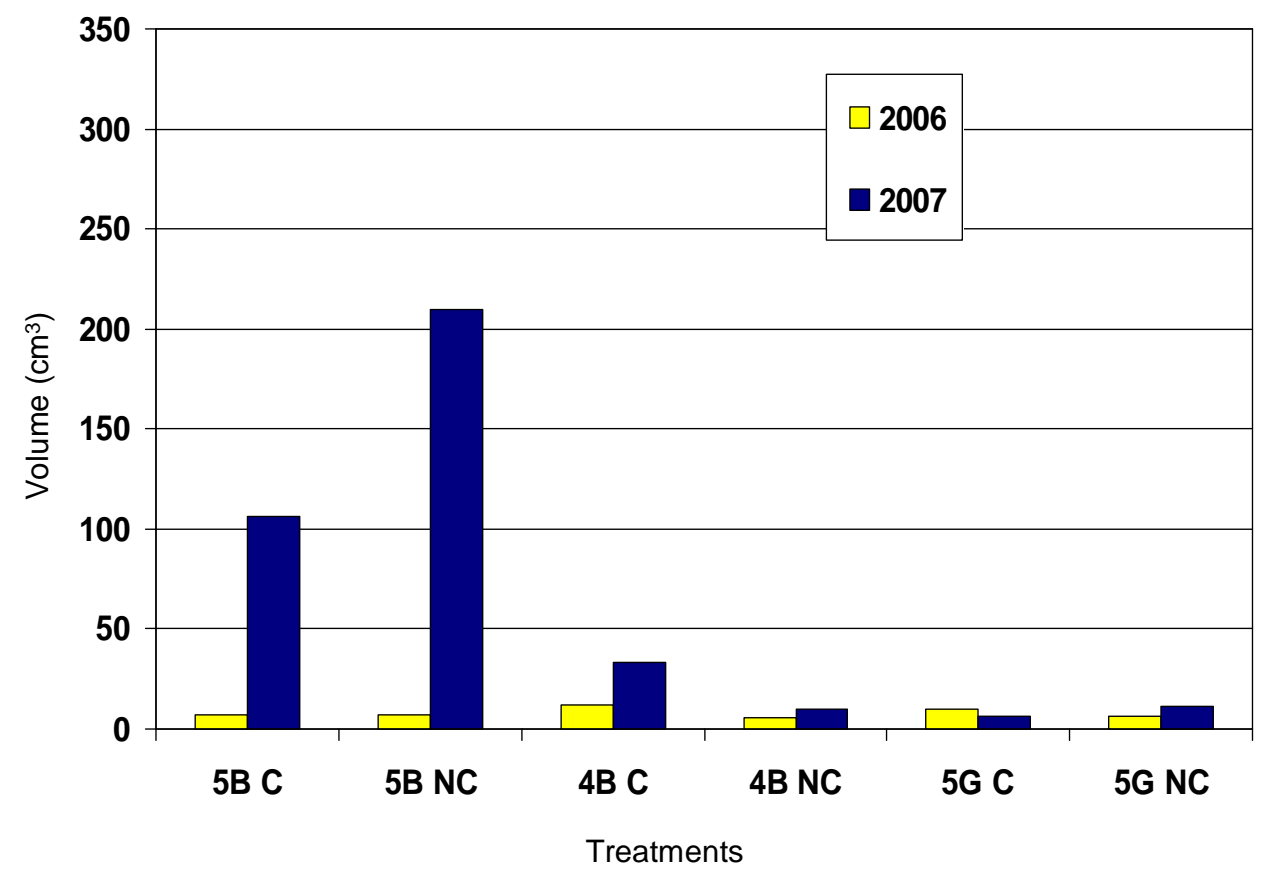

Figure 2A. Average volume of White pine across all treatments after three growing seasons at Catenary Coal Mine, Kanawha County, West Virginia.

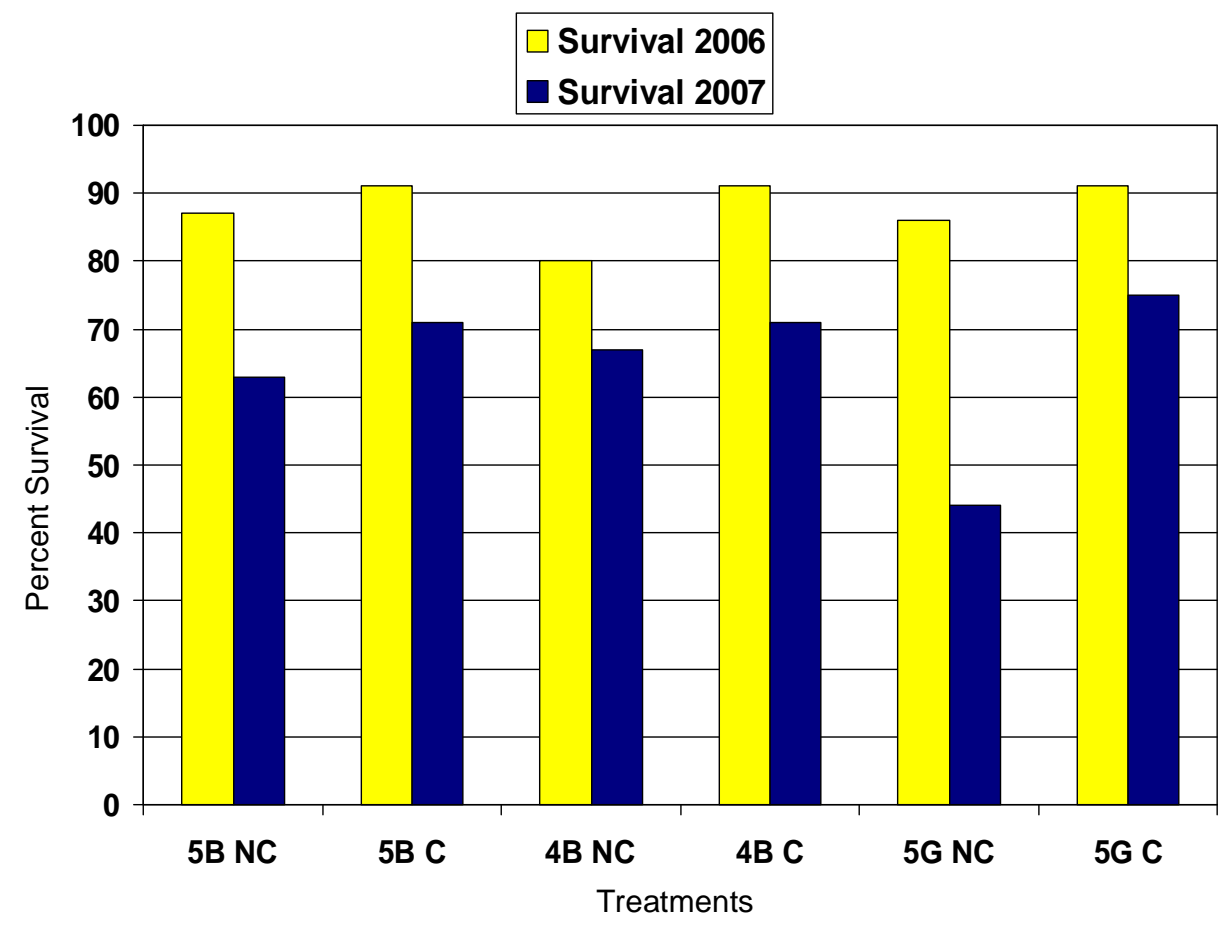

Figure 2B. Average survival of White pine across all treatments after three growing seasons at Catenary Coal Mine, Kanawha County, West Virginia. 


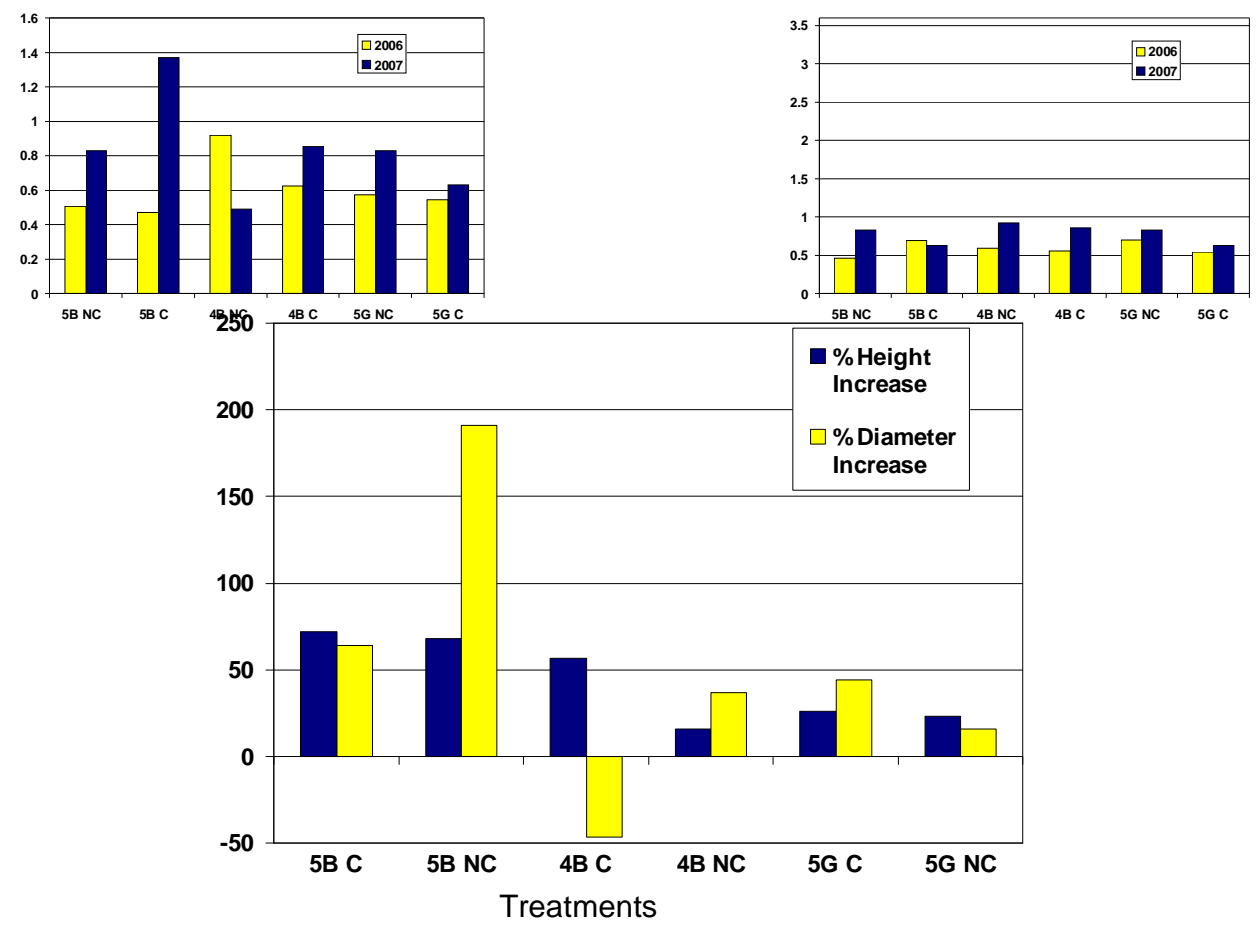

Figure 2C. Average height, diameter, and percent increase of White pine across all treatments after three growing seasons at Catenary Coal Mine, Kanawha County, West Virginia. 
Black cherry has a large and varied natural region ranging from Nova Scotia to eastern Texas, but grows best on north and east facing slopes (Hicks, 1998). In undisturbed native forest, Black cherry can grow $1 \mathrm{~m}$ in height and $1.27 \mathrm{~cm}$ in diameter a year for the first 20 years (Harlow and Harrar, 1968). Black cherry is known to have rapid early growth (Harlow and Harrar, 1968; Hicks, 1998) and on good sites can have such rapid growth in height and diameter that it can out-compete maples and beeches (Hicks, 1998). Black cherry had the third highest volume with $170.8 \mathrm{~cm}^{3}$ (Figure 3A3C), however, it only averaged a $40 \%$ increase in height and a $114 \%$ increase in diameter, both below the average across all species, which was $62 \%$ and $130 \%$ respectively. Black cherry also invades into areas where it was not planted. Zeleznik and Skousen (1996) found Black cherry to volunteer into at least one plot of each of their three different sites. Ashby (1996a) also showed Black cherry to volunteer into multiple sites. Black cherry is considered intolerant to shade, but as a seedling is more tolerant.

Average volume of all oak species (Red, White, and Chestnut) was $68.8 \mathrm{~cm}^{3}$, just below the median of all species $95.0 \mathrm{~cm}^{3}$ (Figures 4A-4C, 5A-5C, and 6A-6C). This was anticipated as Red, White, and Chestnut oaks all commonly emphasize root growth over shoot growth for the first few years (Ledig, 1983). Red oak averaged $84.9 \mathrm{~cm}^{3}$ of volume, the highest of the three oak species. 


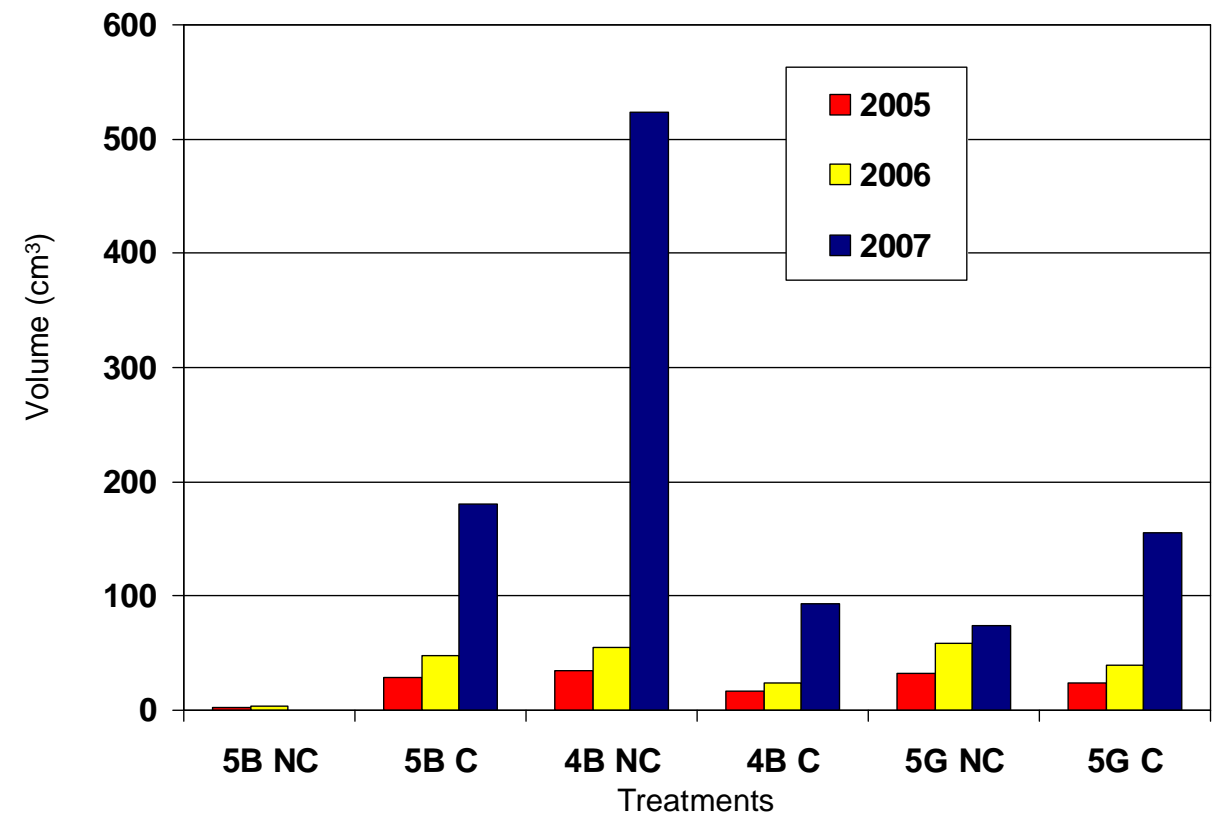

Figure 3A. Average volume of Black cherry across all treatments after three growing seasons at Catenary Coal Mine, Kanawha County, West Virginia.

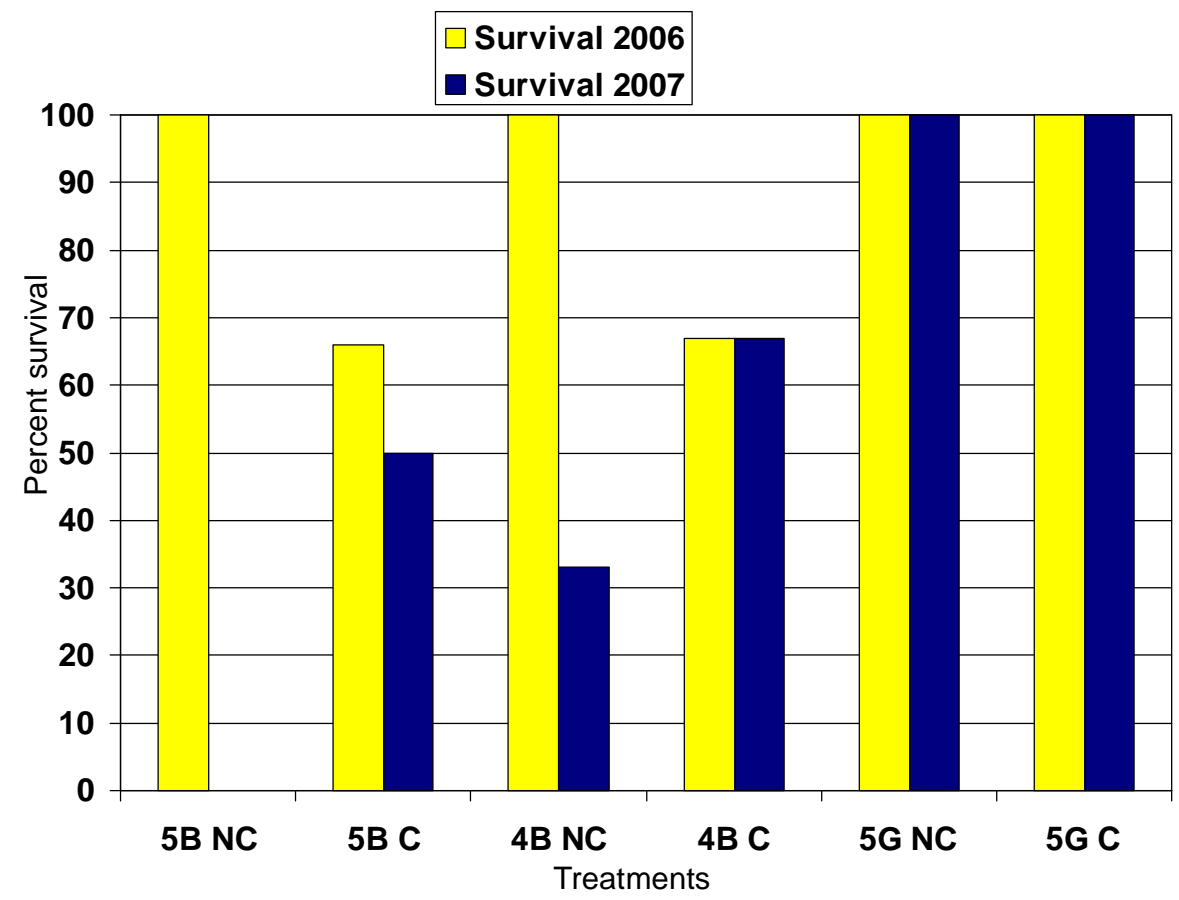

Figure 3B. Average survival of Black cherry across all treatments after three growing seasons at Catenary Coal Mine, Kanawha County, West Virginia. 


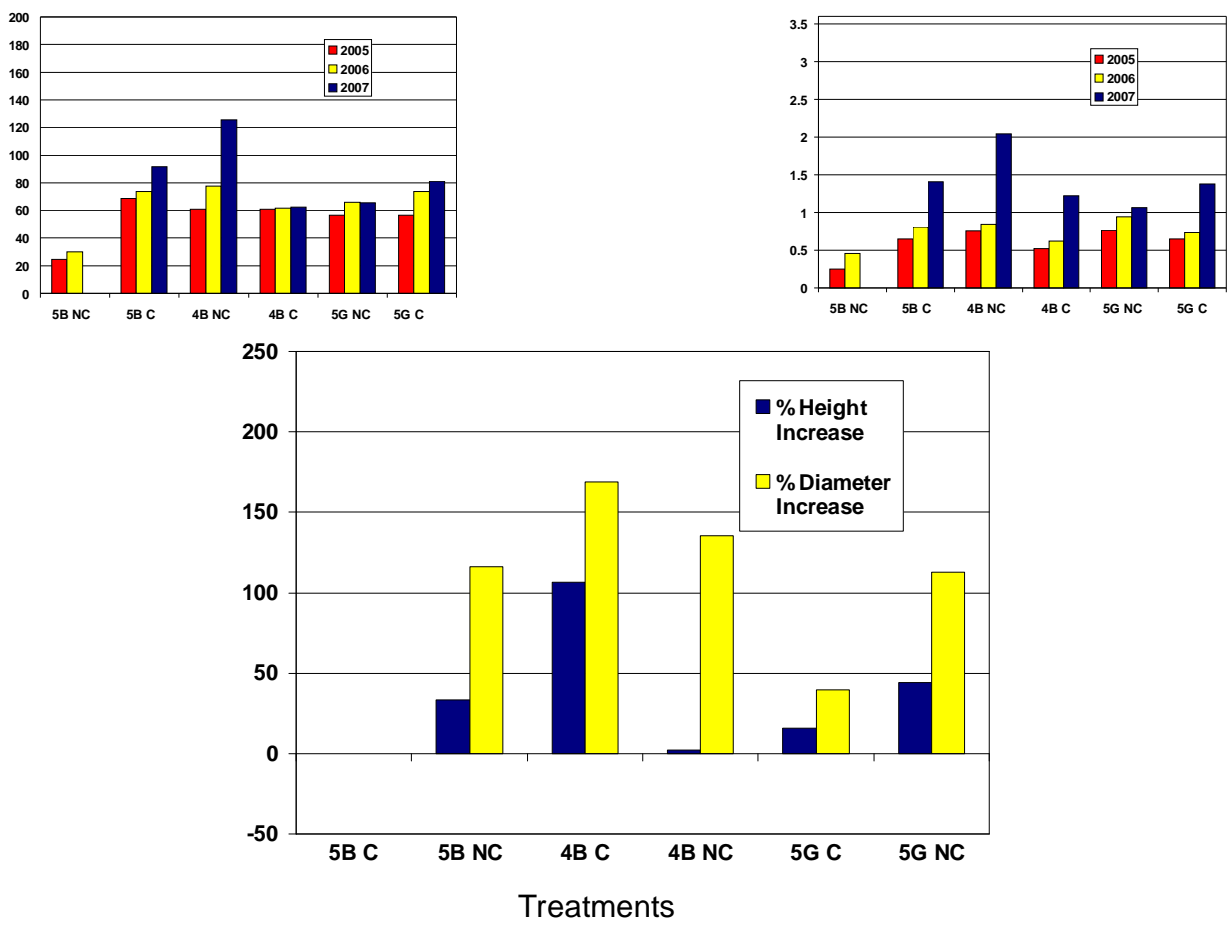

Figure 3C. Average height, diameter, and percent increase of Black cherry across all treatments after three growing seasons at Catenary Coal Mine, Kanawha County, West Virginia. 


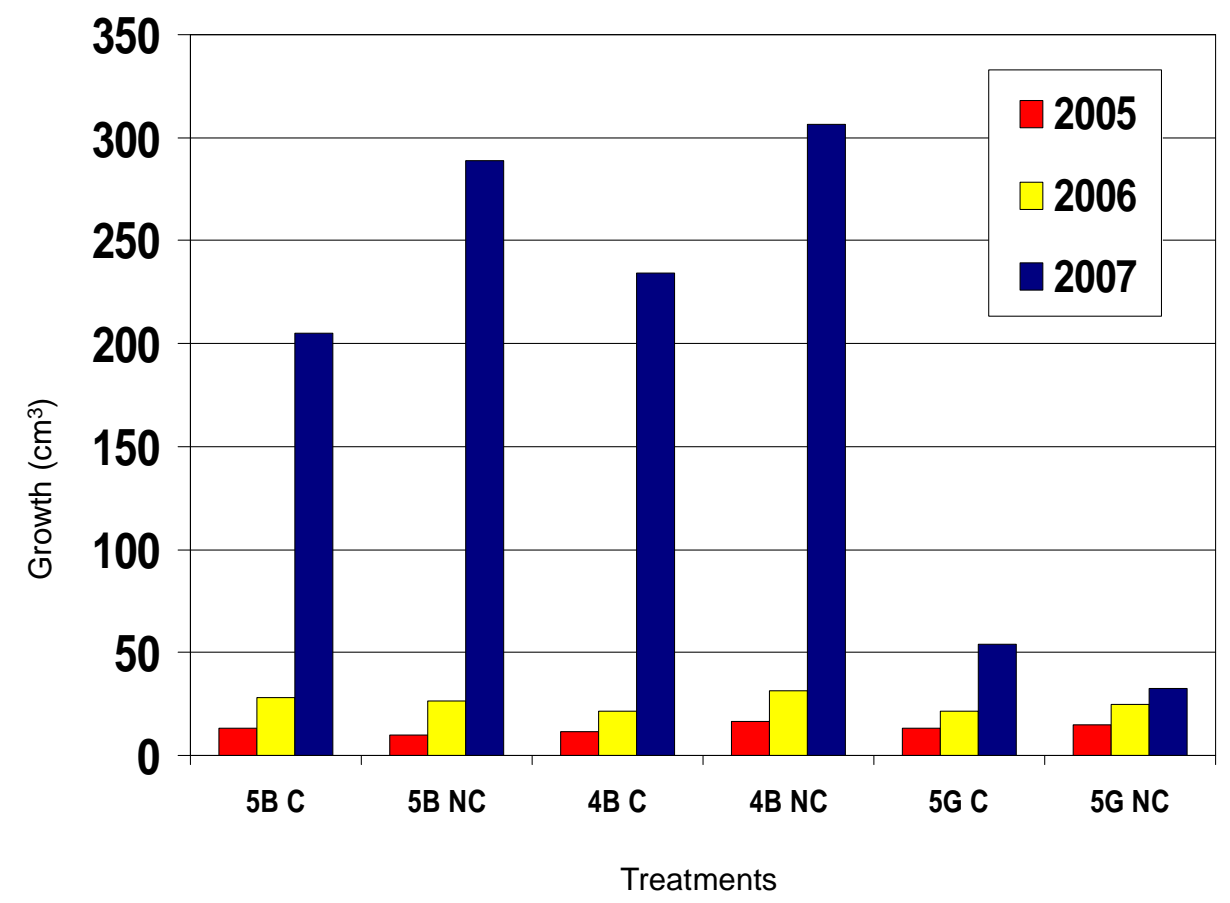

Figure 4A. Average volume of Red oak across all treatments after three growing seasons at Catenary Coal Mine, Kanawha County, West Virginia.

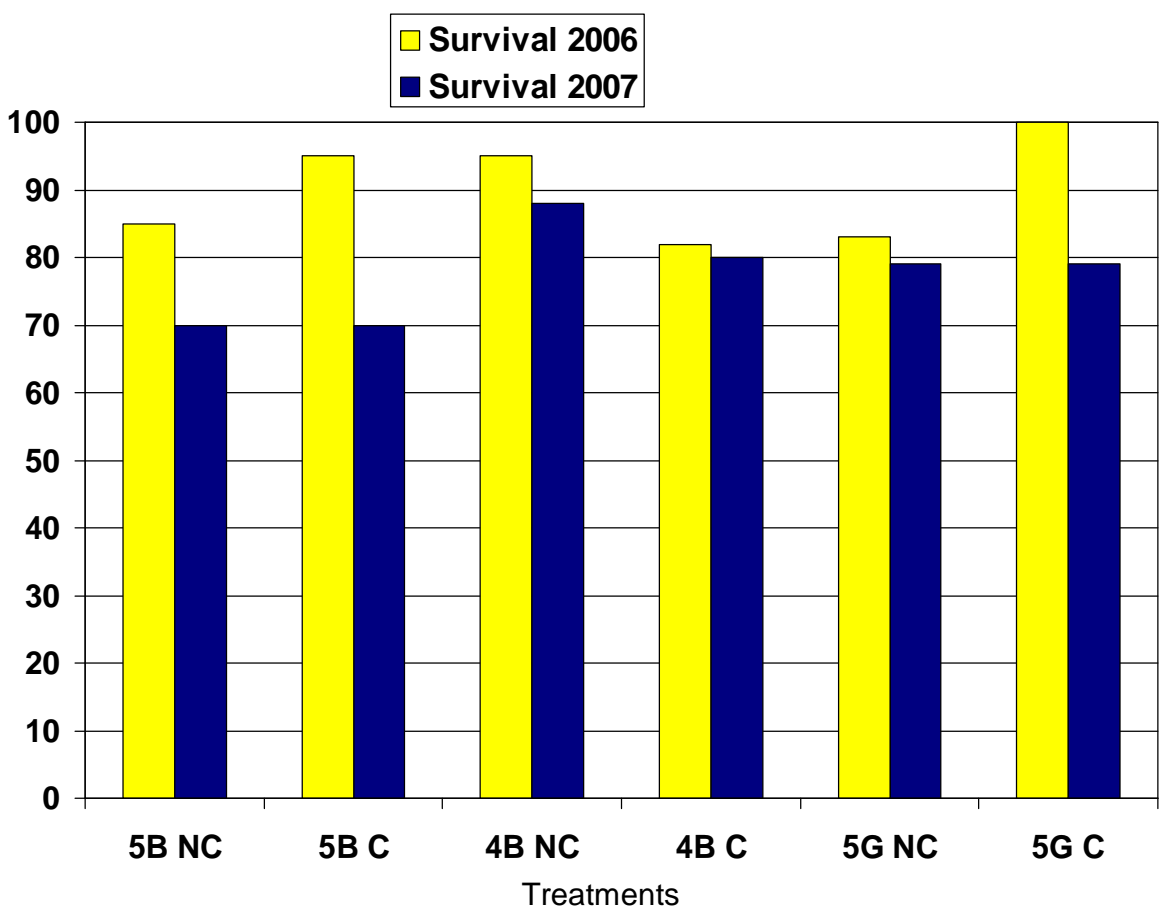

Figure 4B. Average survival of Red oak across all treatments after three growing seasons at Catenary Coal Mine, Kanawha County, West Virginia. 


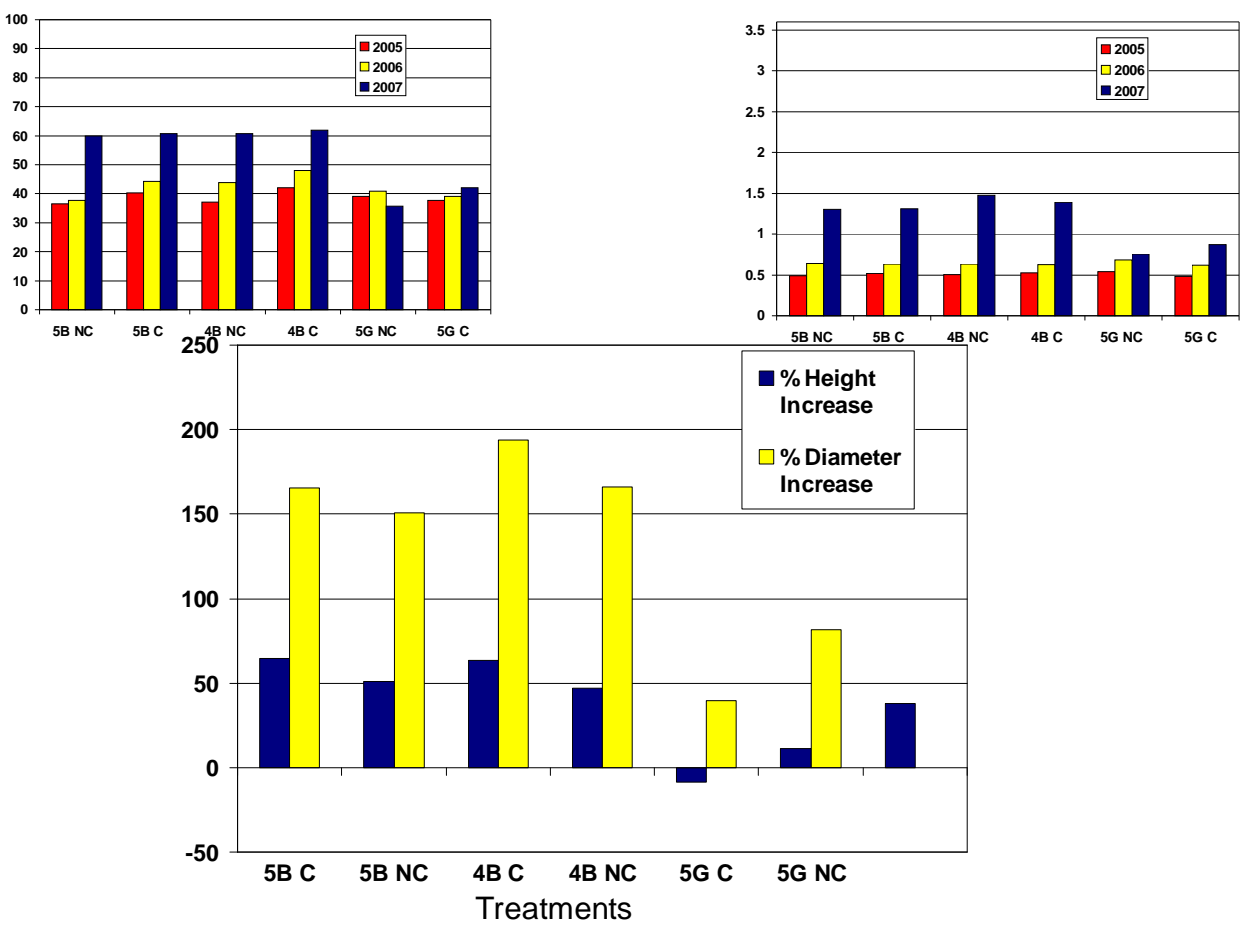

Figure 4C. Average height, diameter, and percent increase of Red oak across all treatments after three growing seasons at Catenary Coal Mine, Kanawha County, West Virginia. 


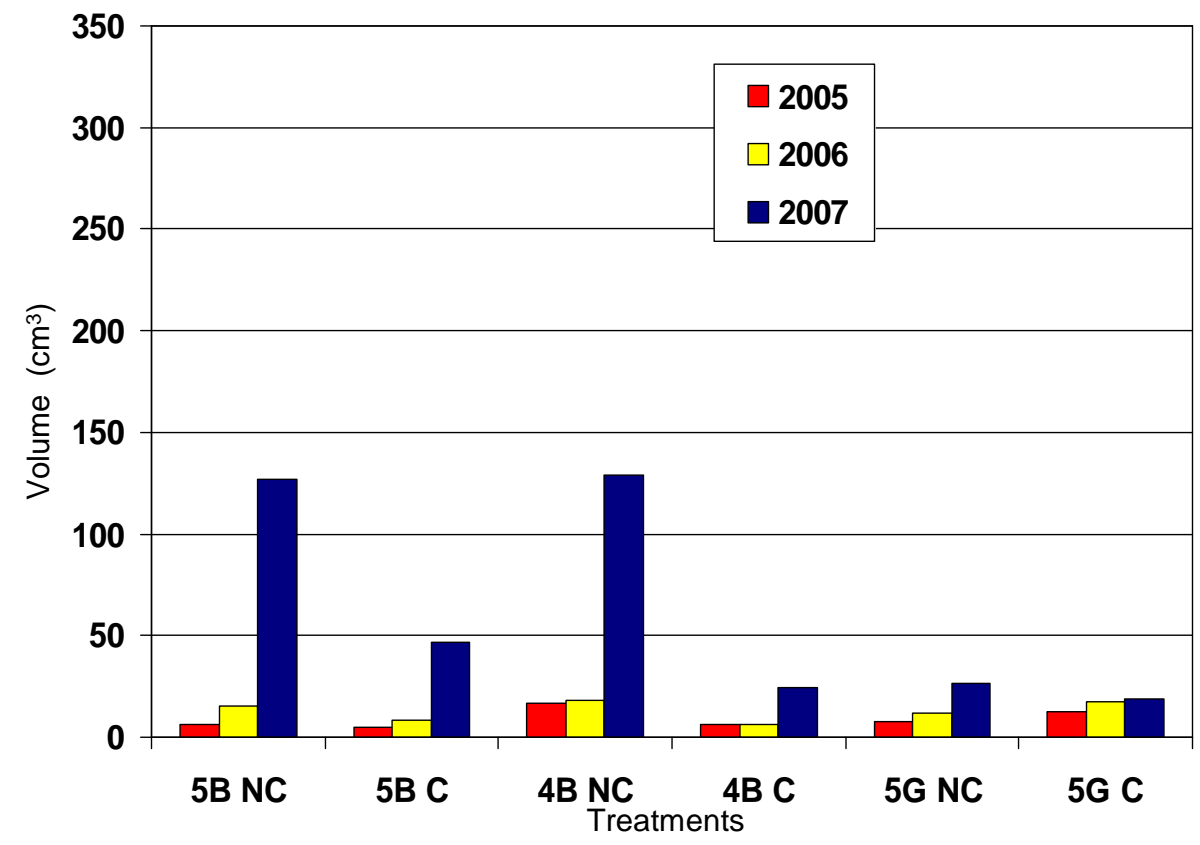

Figure 5A. Average volume of Chestnut oak across all treatments after three growing seasons at Catenary Coal Mine, Kanawha County, West Virginia.

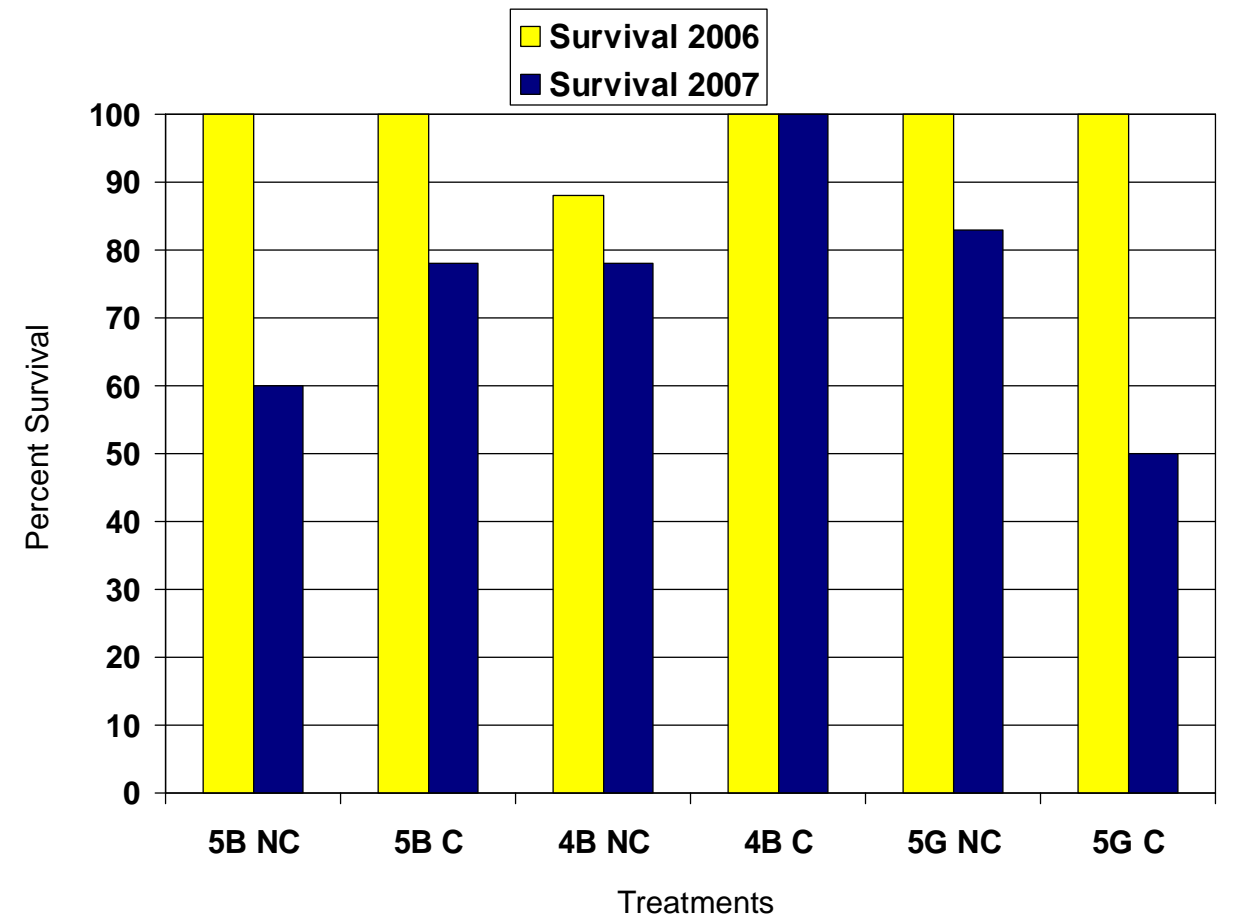

Figure 5B. Average survival of Chestnut oak across all treatments after three growing seasons at Catenary Coal Mine, Kanawha County, West Virginia. 


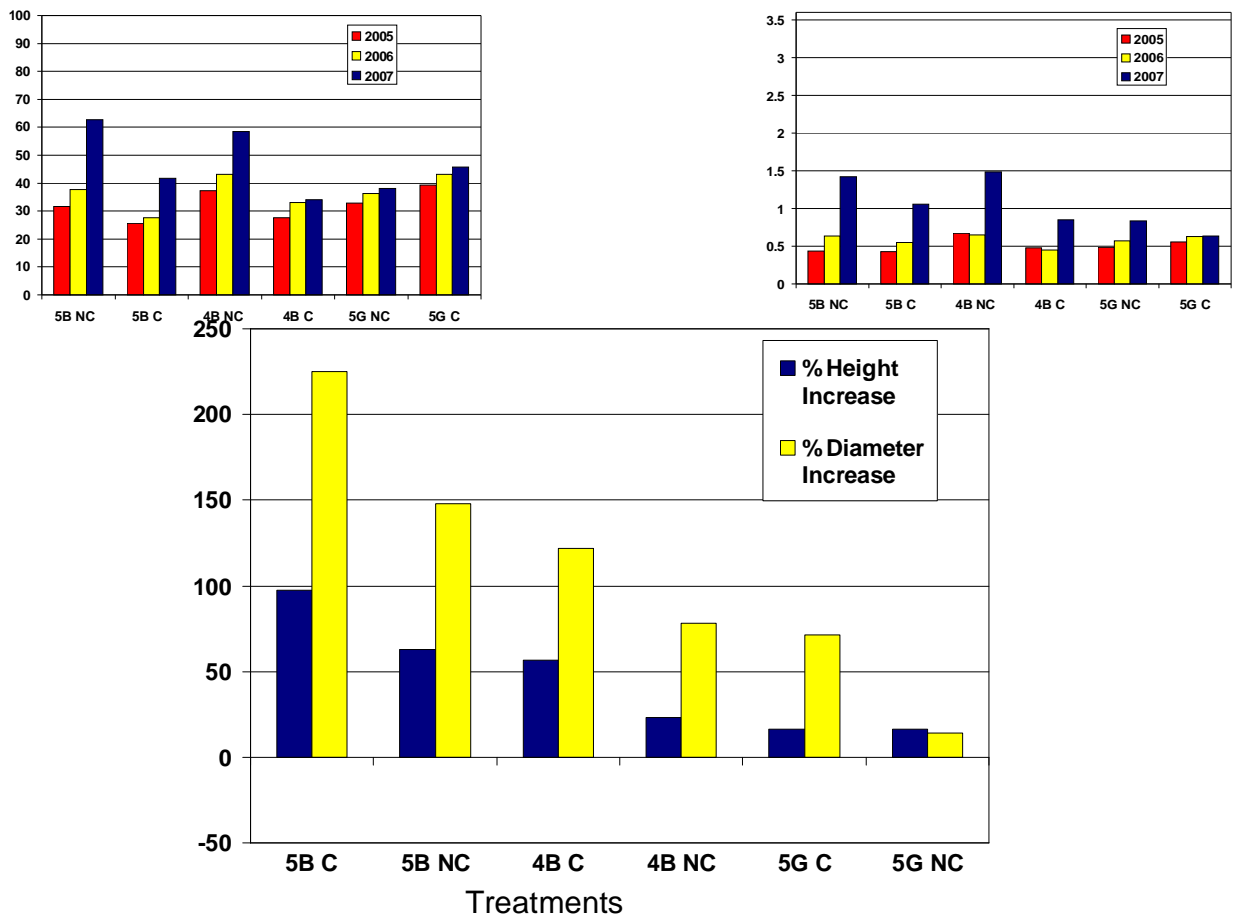

Figure 5C. Average height, diameter, and percent increase of Chestnut oak across all treatments after three growing seasons at Catenary Coal Mine, Kanawha County, West Virginia. 


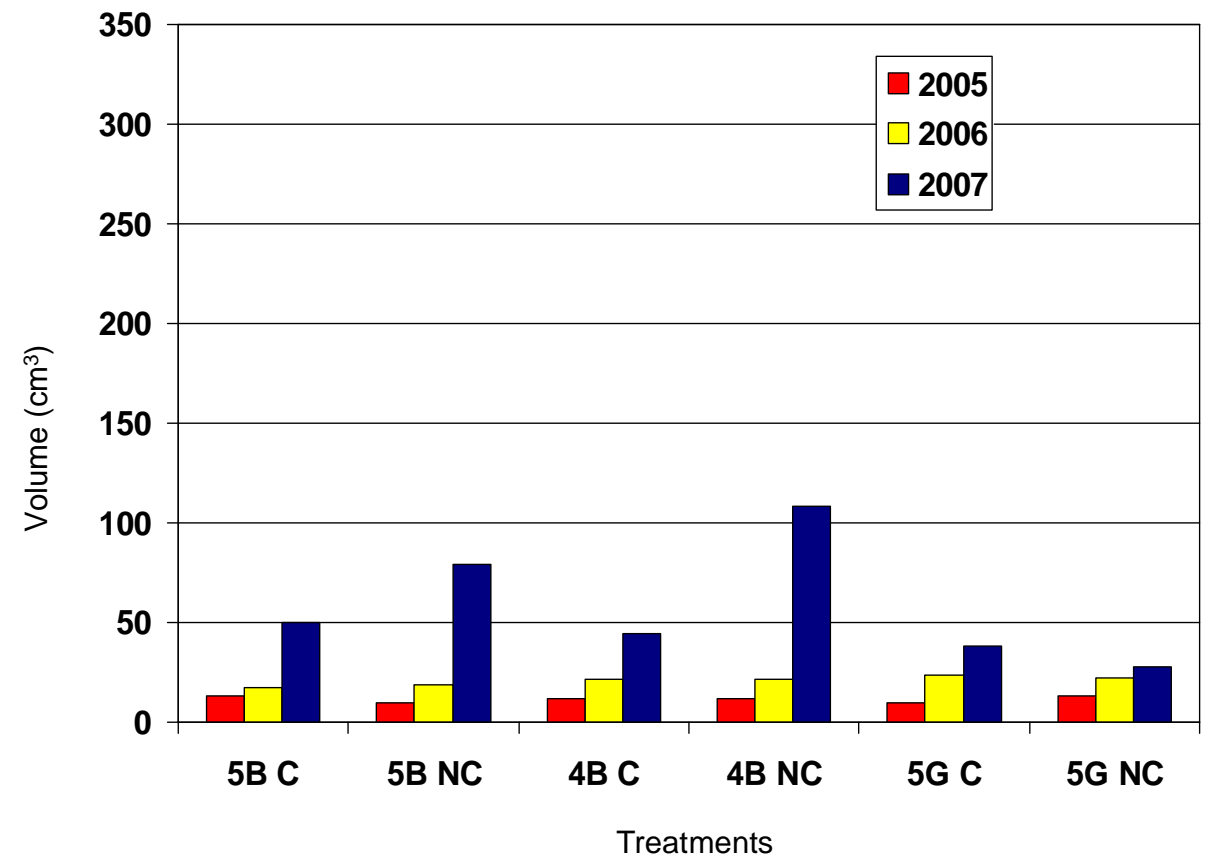

Figure 6A. Average volume of White oak across all treatments after three growing seasons at Catenary Coal Mine, Kanawha County, West Virginia.

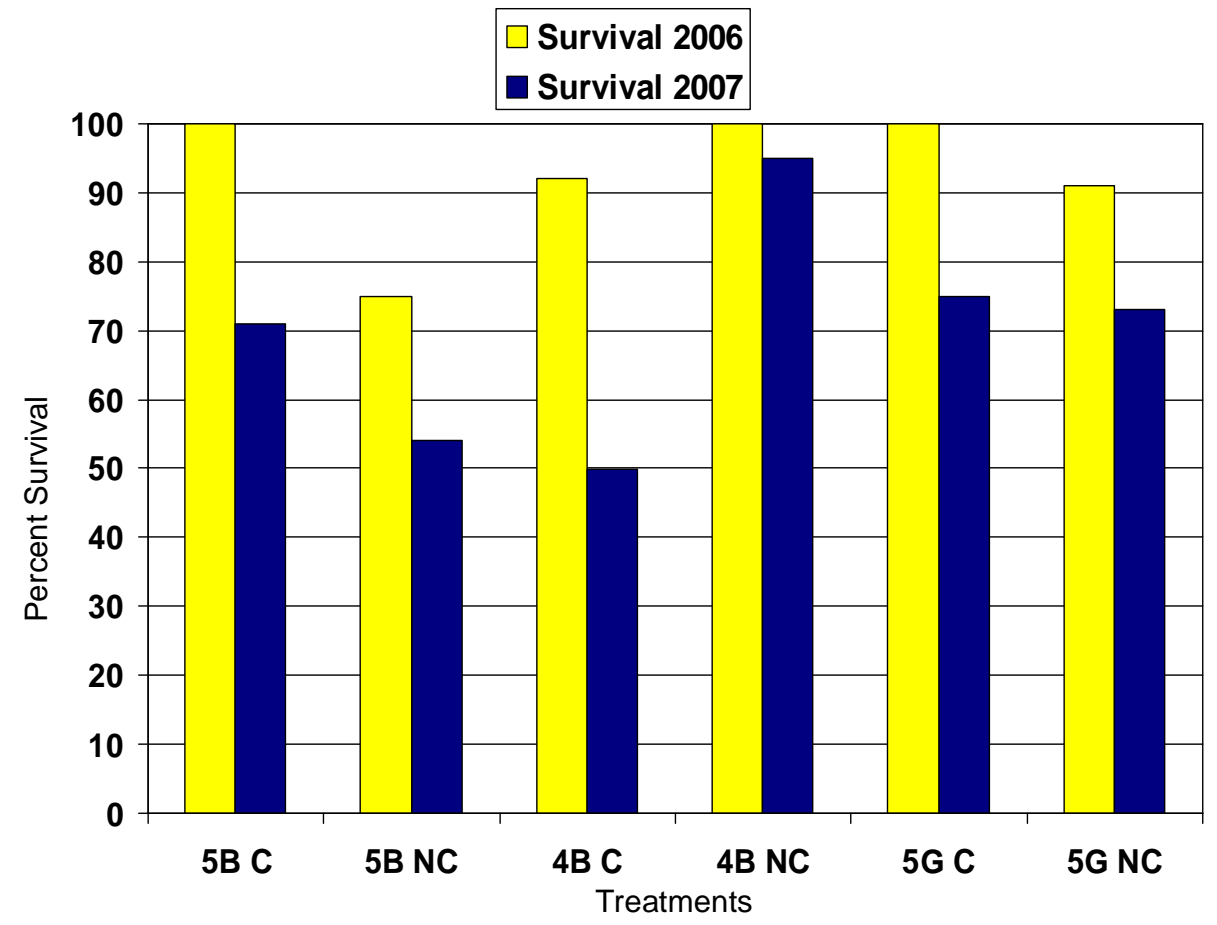

Figure 6B. Average survival of White oak across all treatments after three growing seasons at Catenary Coal Mine, Kanawha County, West Virginia. 


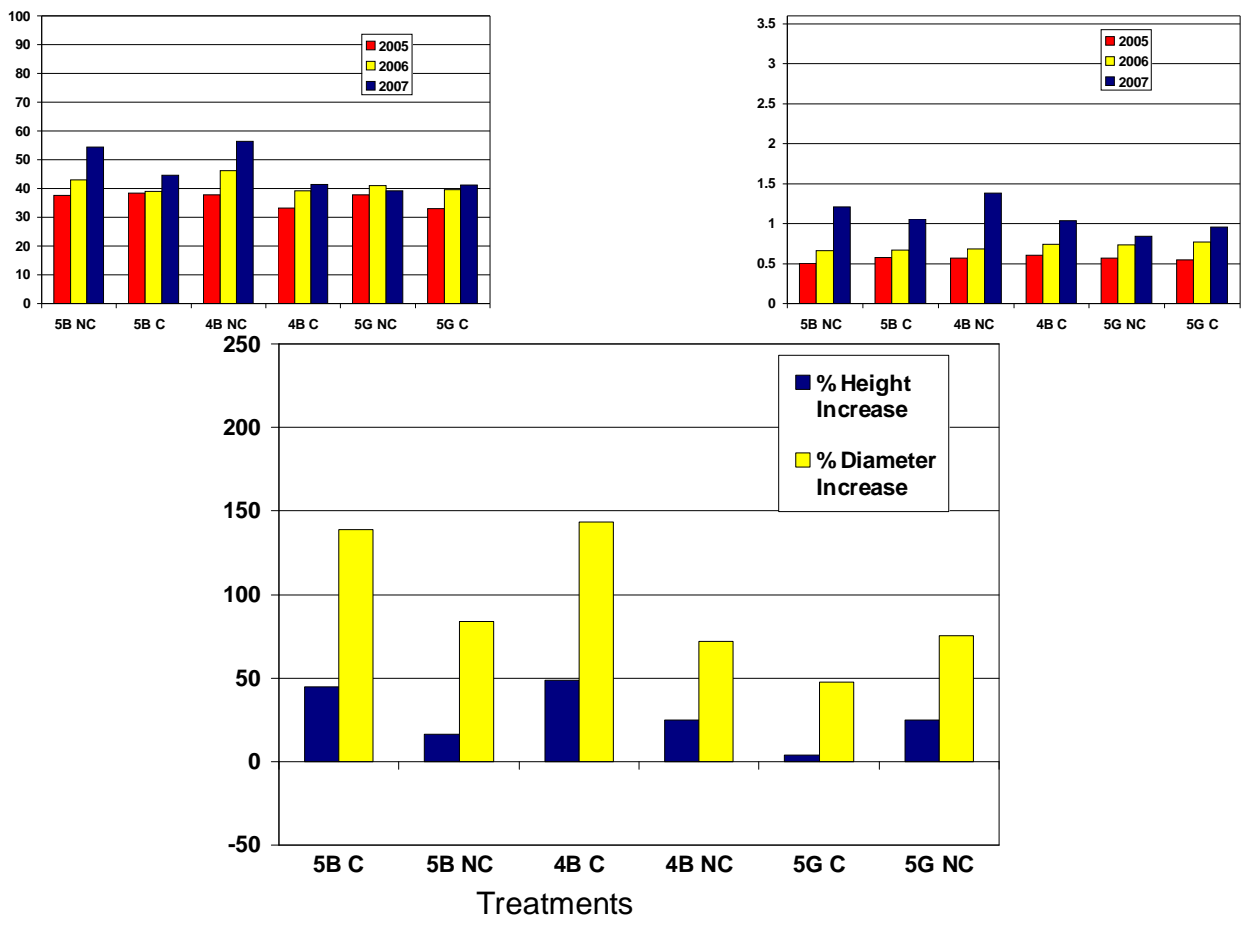

Figure 6C. Average height, diameter, and percent increase of White oak across all treatments after three growing seasons at Catenary Coal Mine, Kanawha County, West Virginia. 
This result was expected as Red oak is one of the fastest growing native oaks in North America (Hicks, 1998). Red oak has a broad site tolerance and has been known to grow from sea-level to over $1500 \mathrm{~m}$ in elevation. However, it prefers well-drained soils of concave slopes on north and northeast aspects (Hicks, 1998). Red oak has intermediate shade tolerance, but is considered less tolerant than White or Chestnut oaks. Red oak also had the greatest percent diameter increase (133\%) of the three oak species, but was second of the oaks in percent height increase (38\%).

White oak is the most common and widely distributed of all North American oaks (Hicks, 1998). Most oaks (especially White) are late-successional species which are poorly adapted to early-successional conditions such as direct sunlight and barren soils. This was shown by White oak having the lowest volume $\left(58.0 \mathrm{~cm}^{3}\right)$, percent height increase (27\%), percent diameter increase (94\%), and survival (70\%) of the three oak species planted. White oak seedlings and saplings are slower growing than many of the trees they are associated with, and if growing in a mixed even-age stand, White oak will be over-topped by Tulip poplar, Black cherry, Red oak, and White pine. However, due to White oak's longevity and intermediate shade tolerance, it can exist as a mid-story species until the dominant tree species die back, when it will ultimately prevail as a dominant species (Hicks, 1998).

Chestnut oaks are in the White oak group, but are generally found on poor quality upland sites. However, they grow best in alluvial soils found on benches and in coves (Ike and Huppuch, 1968). Of the three oak species planted, Chestnut oak was second in both volume $\left(62.1 \mathrm{~cm}^{3}\right)$ and survival $(76 \%)$. However, it did have the greatest percent height increase (45\%) of the three oak species and over a $100 \%$ increase in diameter 
(110\%). Chestnut oaks are considered to be specialist, as they are tolerant of harsh site conditions where competition is not great. Oaks prefer to regenerate in deep, fertile soils where a diversity of microorganisms can facilitate below ground growth (Burger et al., 2002). As such, oak growth should be relatively slow on these newly constructed soils.

Dogwood and Redbud have been commonly described to grow well in early successional environments like mine sites (Burger et al., 2005b). Dogwood and Redbud had the fourth and fifth greatest volume of all species with $139.6 \mathrm{~cm}^{3}$ and $94.9 \mathrm{~cm}^{3}$, respectively (Figures 7A-7C and 8A-8C). They also had the third and fourth greatest percent diameter increase of all species (152\% and 143\%, respectively). However, both Redbud and Dogwood had very low percent height increase (12\% and 3\%). The low percent height increase is most likely due to the fact that these two species exhibited a lot of die-back, where the main stem would die, but sprouts would grow from the root-collar area of the samplings. This would explain the large increases in percent diameter, while low percent increases in height. These species are well adapted to early-successional environments and are also highly shade tolerant. They have also been found to commonly volunteer onto mine soils, much like Black cherry (Groninger et al., 2006; Skousen et al., 2006). Their establishment as pioneer species helps convert the environment into a mid-to-late successional environment better suited for the more valuable hardwood species. They do this by adding organic matter to the soil, improving water holding capacity, and some even fix nitrogen in the soil. 


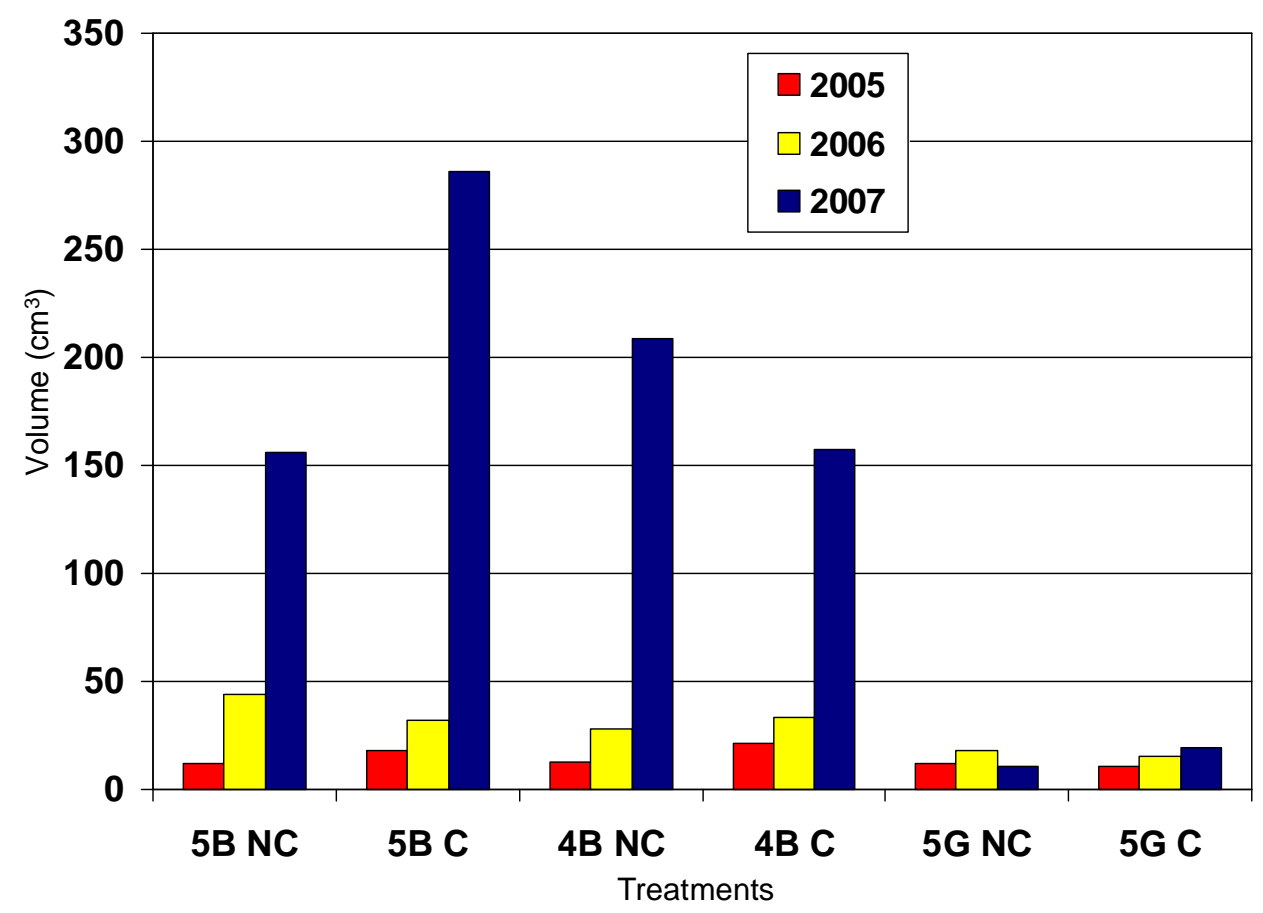

Figure 7A. Average volume of Dogwood across all treatments after three growing seasons at Catenary Coal Mine, Kanawha County, West Virginia.

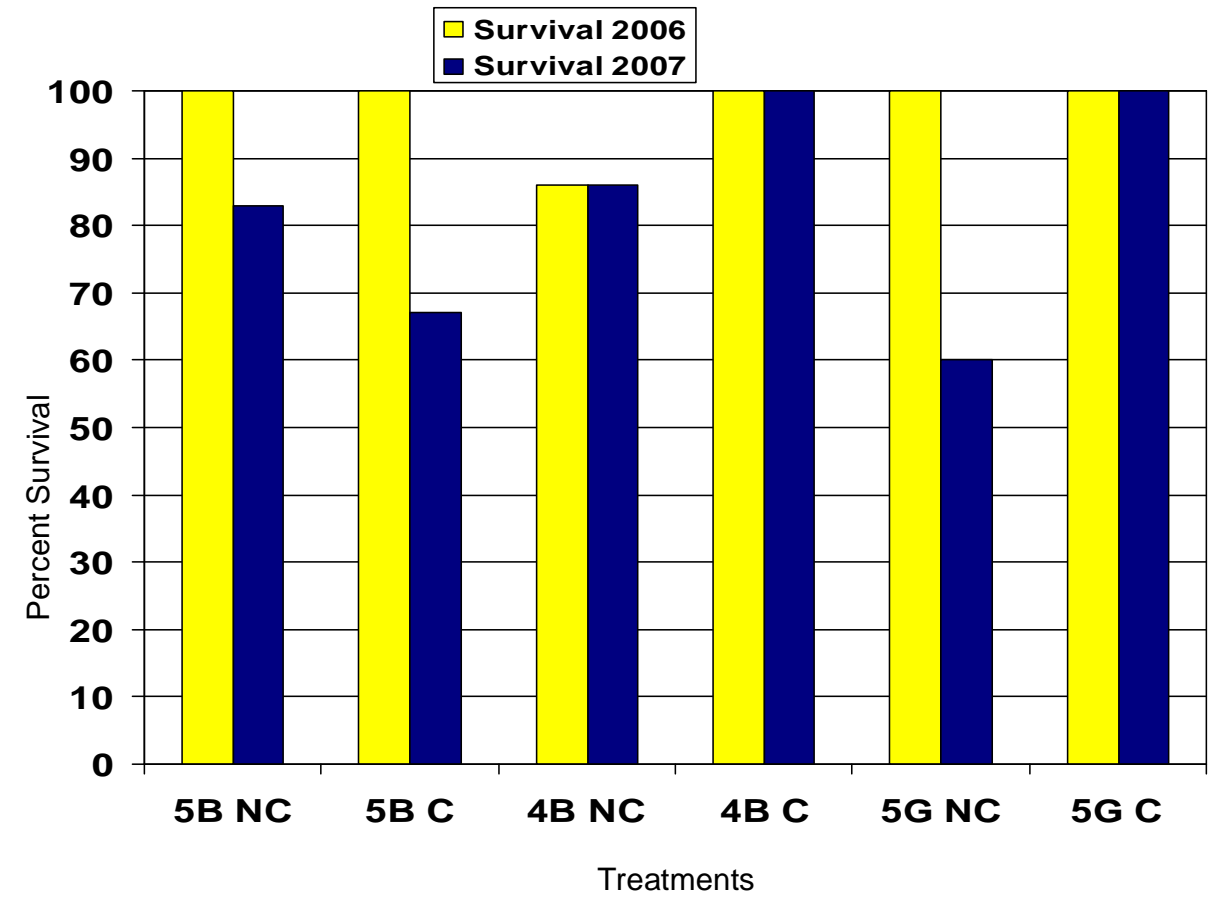

Figure 7B. Average survival of Dogwood across all treatments after three growing seasons at Catenary Coal Mine, Kanawha County, West Virginia. 


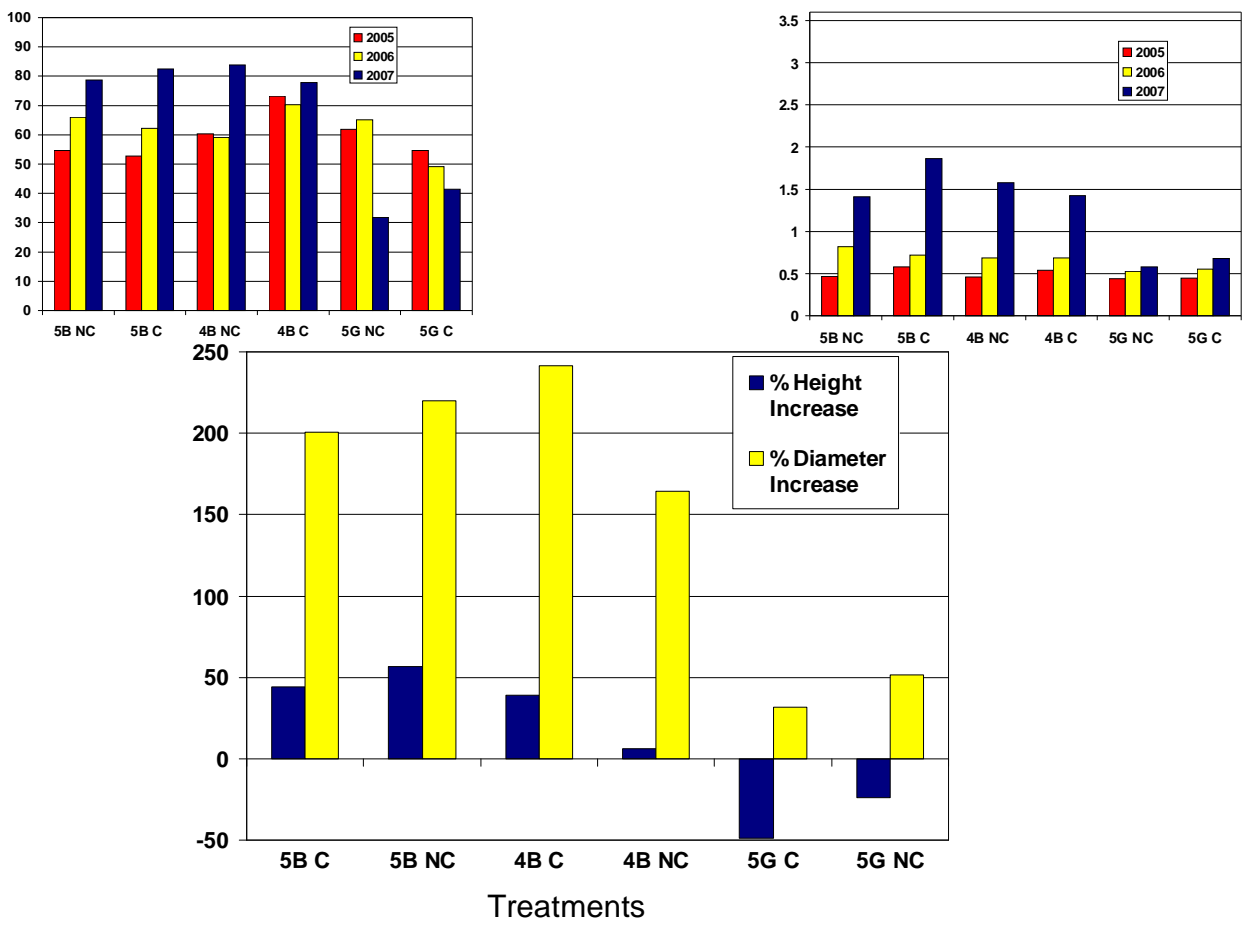

Figure 7C. Average height, diameter, and percent increase of Dogwood across all treatments after three growing seasons at Catenary Coal Mine, Kanawha County, West Virginia. 


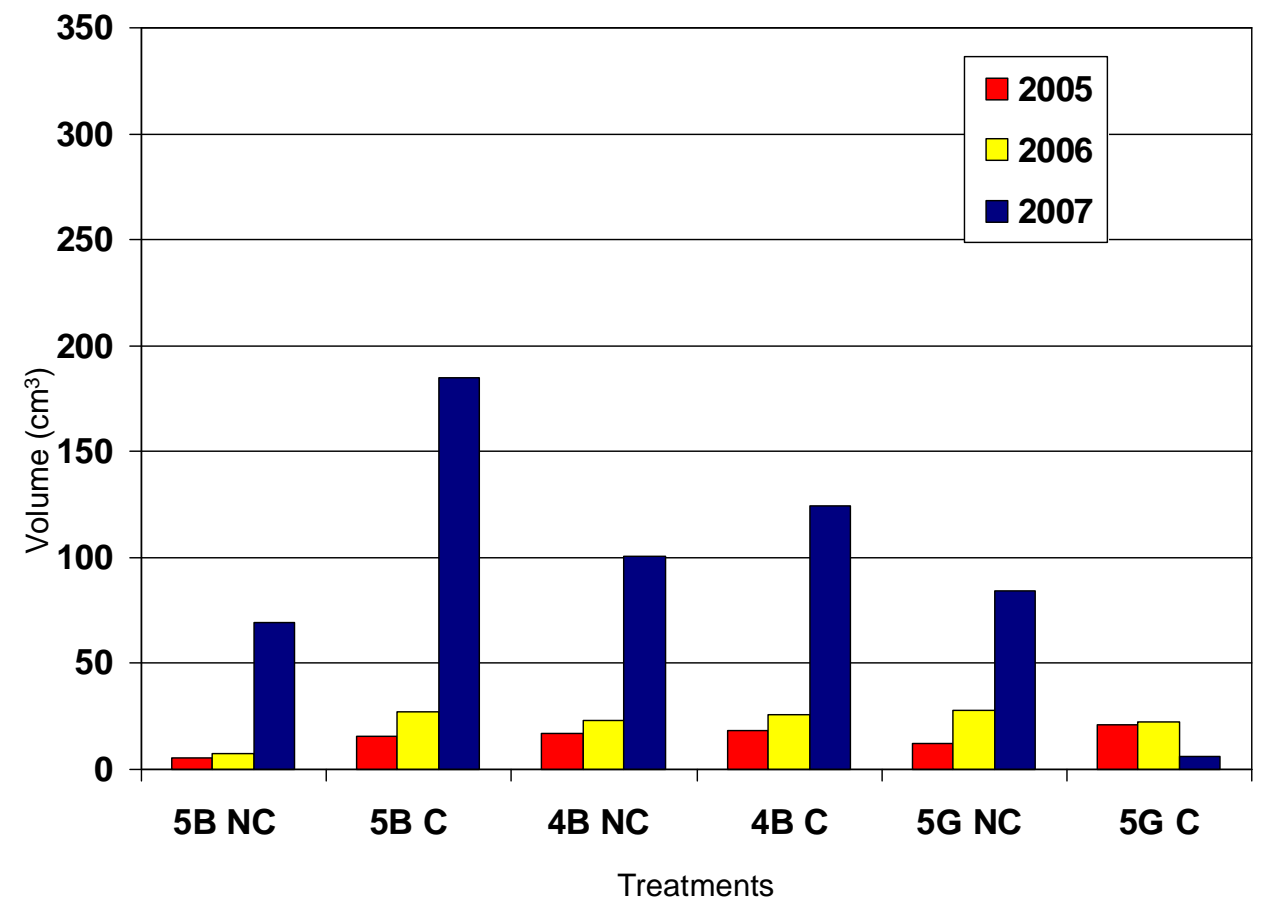

Figure 8A. Average volume of Redbud across all treatments after three growing seasons at Catenary Coal Mine, Kanawha County, West Virginia.

$\square$ Survival 2006

- Survival 2007

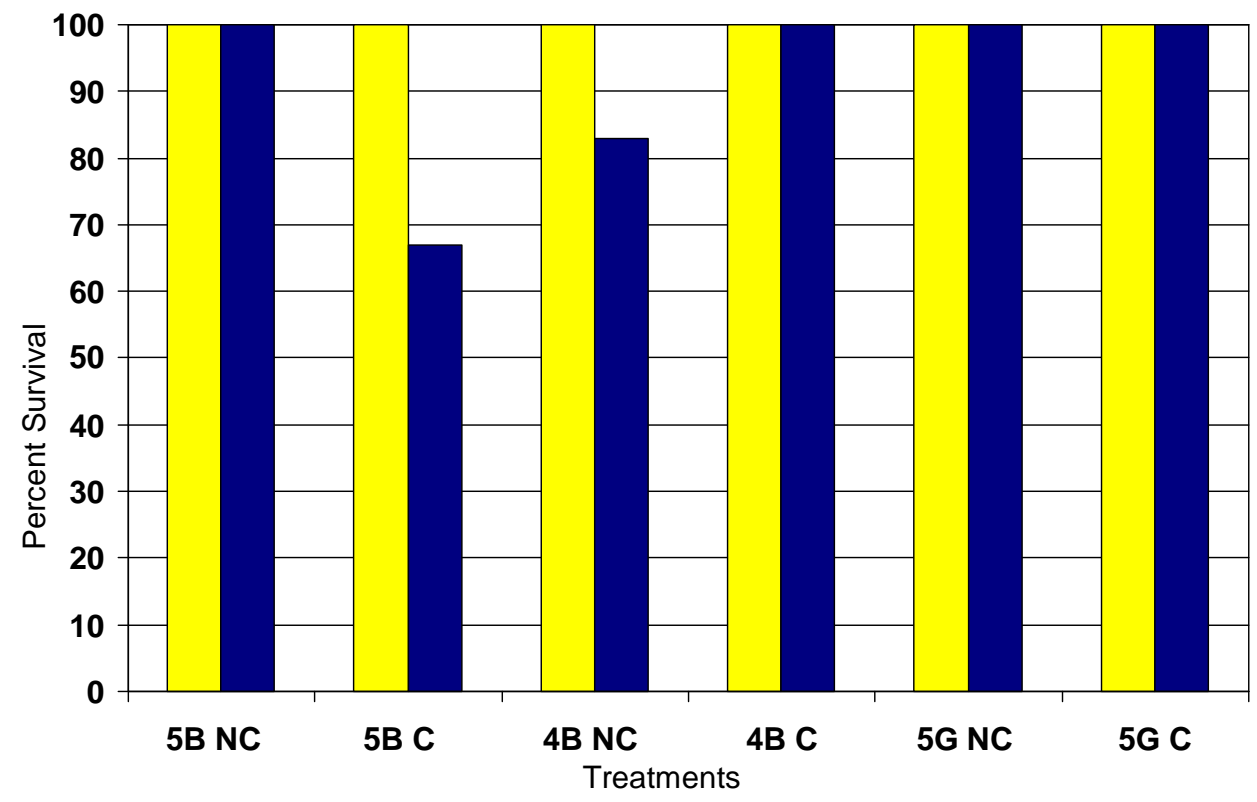

Figure 8B. Average survival of Redbud across all treatments after three growing seasons at Catenary Coal Mine, Kanawha County, West Virginia. 


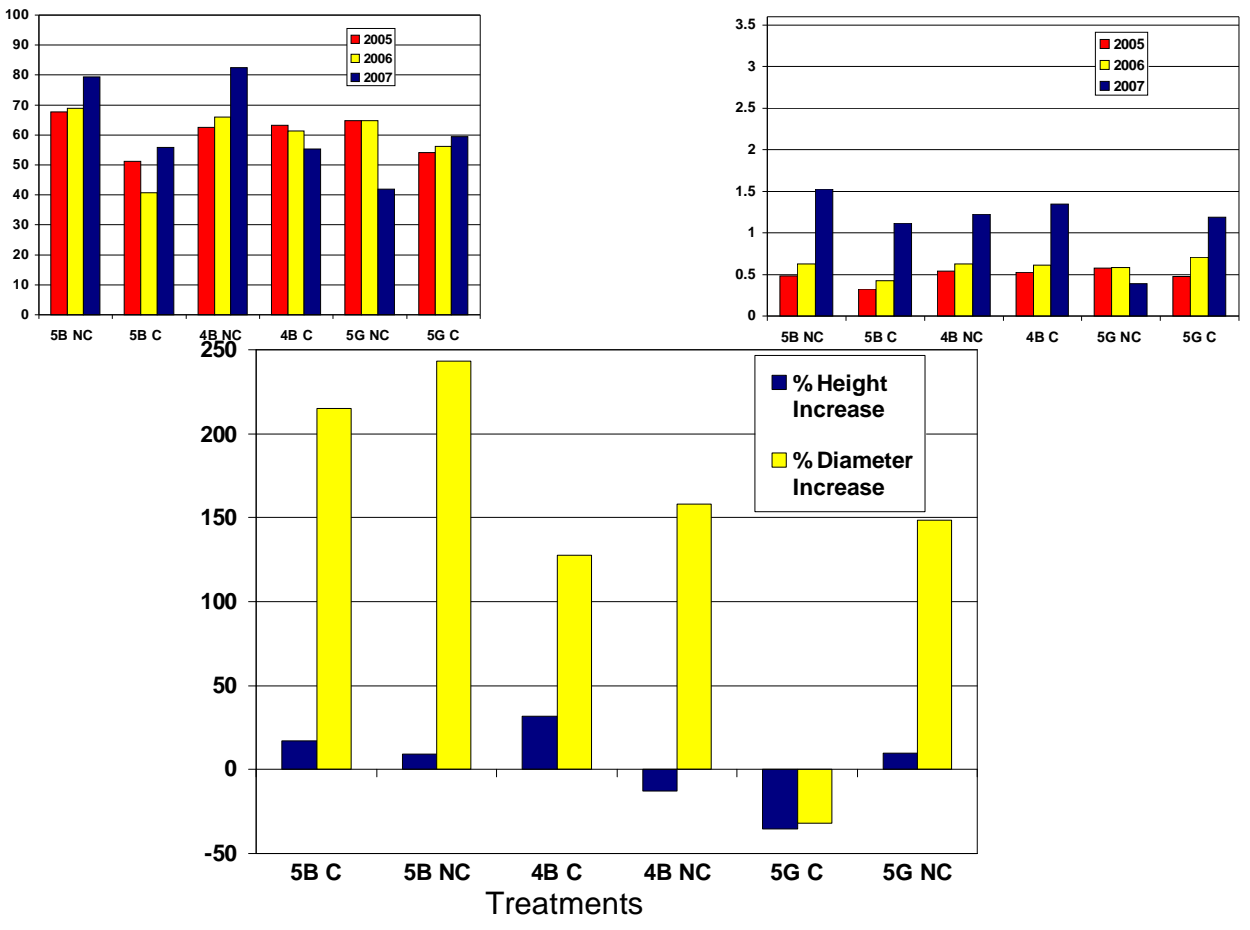

Figure 8C. Average height, diameter, and percent increase of Redbud across all treatments after three growing seasons at Catenary Coal Mine, Kanawha County, West Virginia. 
While Sugar maple had higher than the average survival across all species, $(83 \%$ across all treatments) (Figure 9A-9C) it had generally poor growth. Sugar maple had the second lowest percent height increase with only $12 \%$, and second lowest percent diameter increase with $81 \%$. It also had the second lowest volume with $43.2 \mathrm{~cm}^{3}$. Sugar maple grows best in moist, rich, well drained soils, but can be tolerant of sterile soils (Harlow and Harrar, 1968). However, while Sugar maple can be tolerant of sterile soils, it prefers to develop under heavy forest cover where shade is prevalent through the first few years of development (Harlow and Harrar, 1968). This tolerance, coupled with its slow growth rate (Hicks, 1998), explains the higher than average survival but poor growth. A closely related species, Red maple, is a common volunteer species on mine soils and was noted at this study as well as in Brenner et al. (1984).

Tulip poplar is considered by some to be the most important species in Appalachia because it has the greatest volume in the region (Hicks, 1998). Tulip poplar had the second highest average volume with $175.2 \mathrm{~cm}^{3}$ but was tied with White pine for lowest survival (65\%) (Figure 10A-10C). Tulip poplar also had the third greatest amount of percent height increase with 77\%, and over a 100\% increase in diameter (117\%). Tulip poplar is considered to be intolerant to shade and very site demanding. Aspect is considered to be the greatest controlling factor for Tulip poplar growth (Harlow and Harrar, 1968; Hicks, 1998). Tulip poplars in general have a high growth rate when compared to Red oak (Ledig, 1983), as shown by poplar's high average growth in this study. 


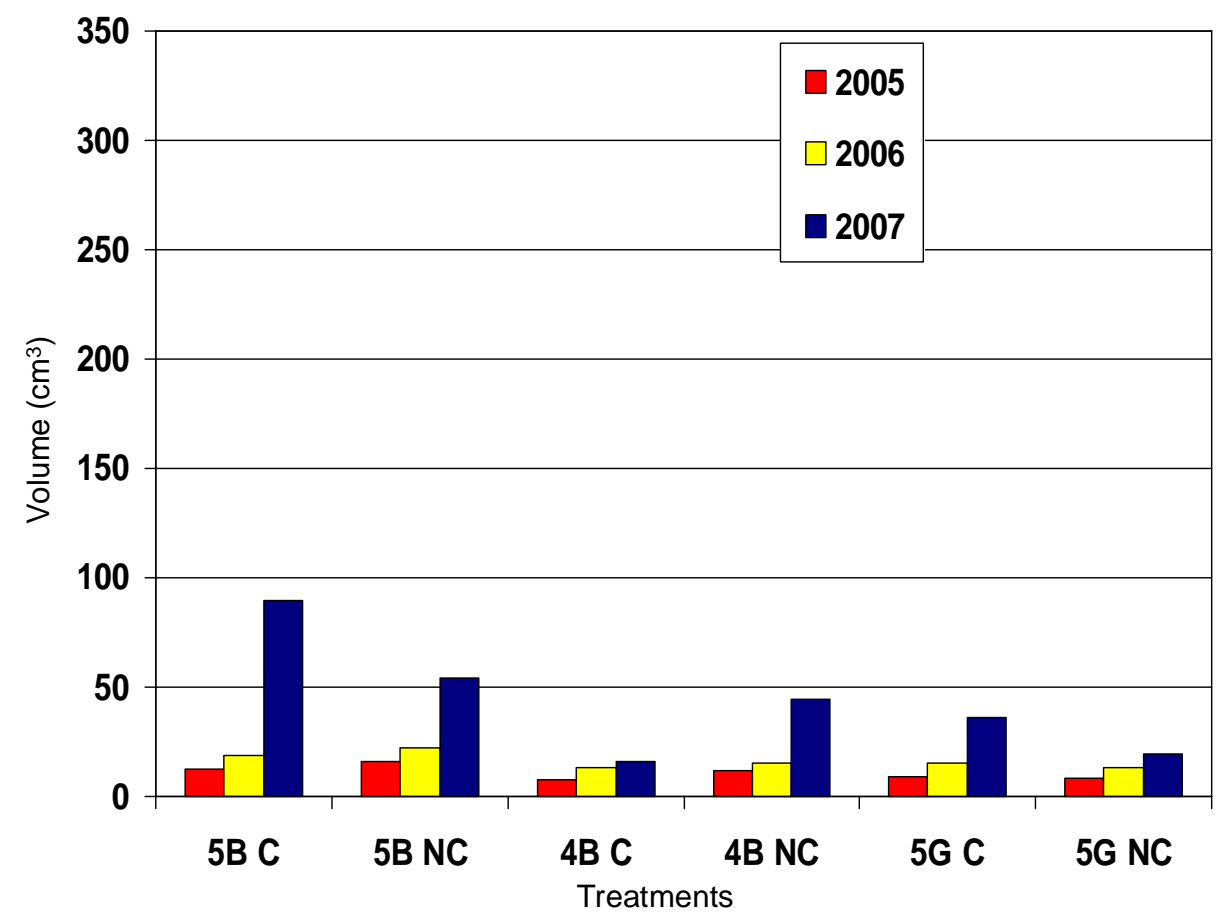

Figure 9A. Average volume of Sugar maple across all treatments after three growing seasons at Catenary Coal Mine, Kanawha County, West Virginia.

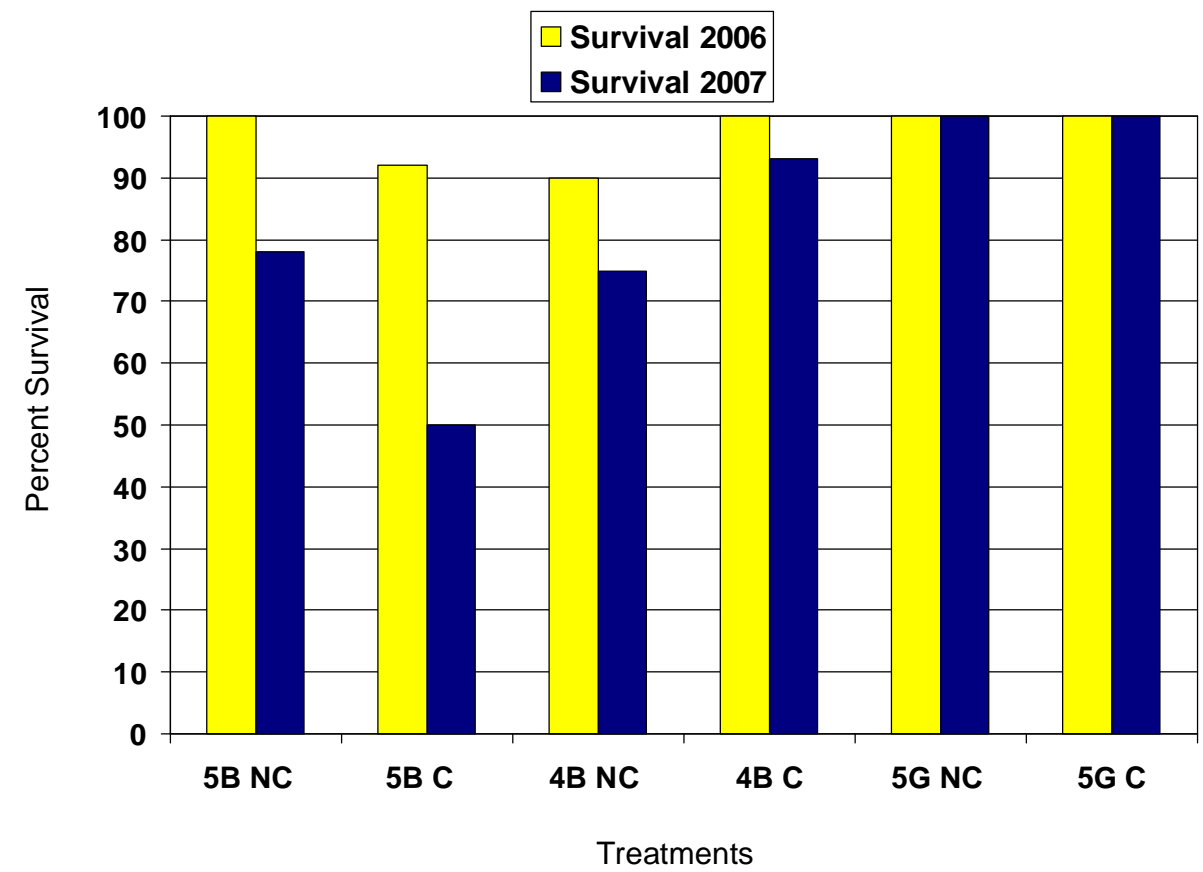

Figure 9B. Average survival of Sugar maple across all treatments after three growing seasons at Catenary Coal Mine, Kanawha County, West Virginia. 


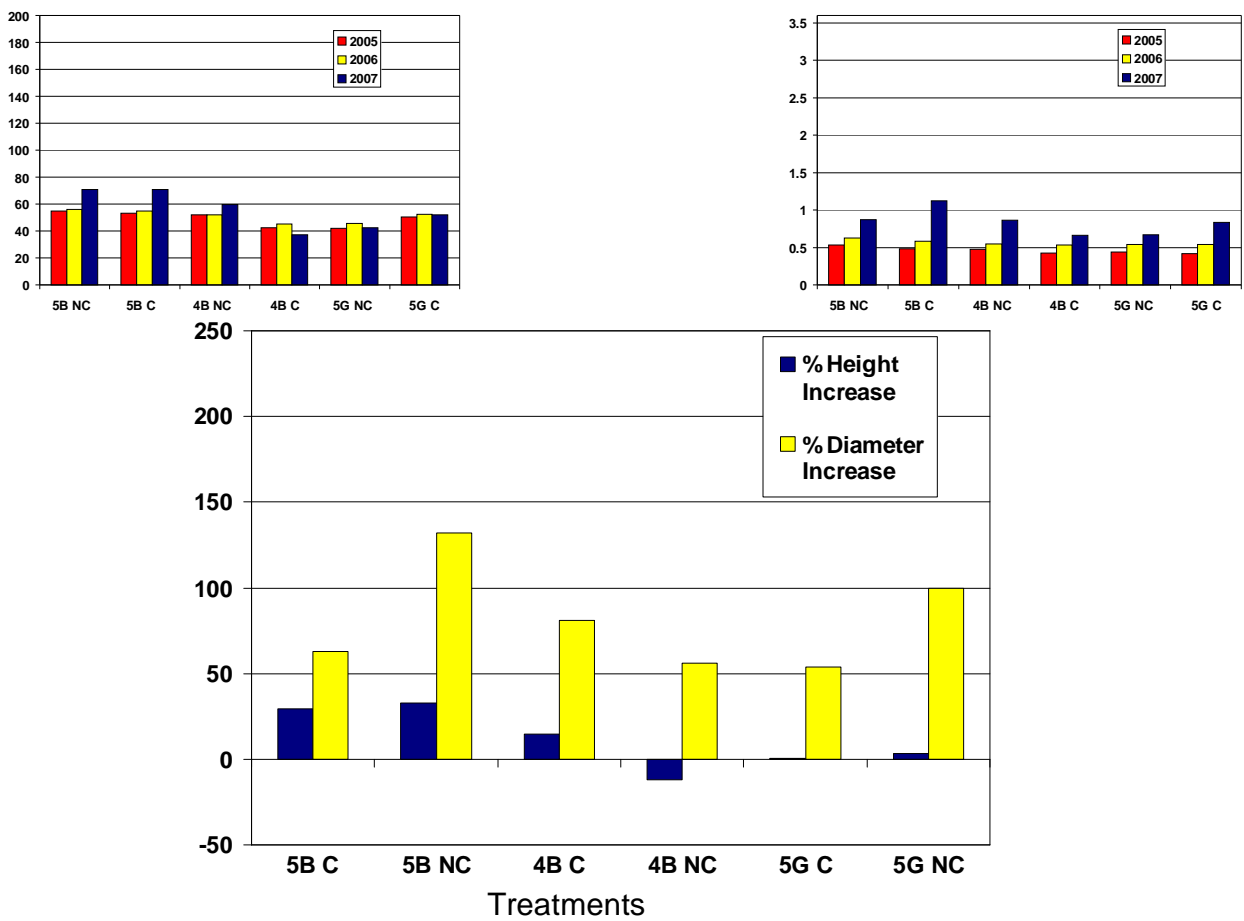

Figure 9C. Average height, diameter, and percent increase of Sugar maple across all treatments after three growing seasons at Catenary Coal Mine, Kanawha County, West Virginia. 


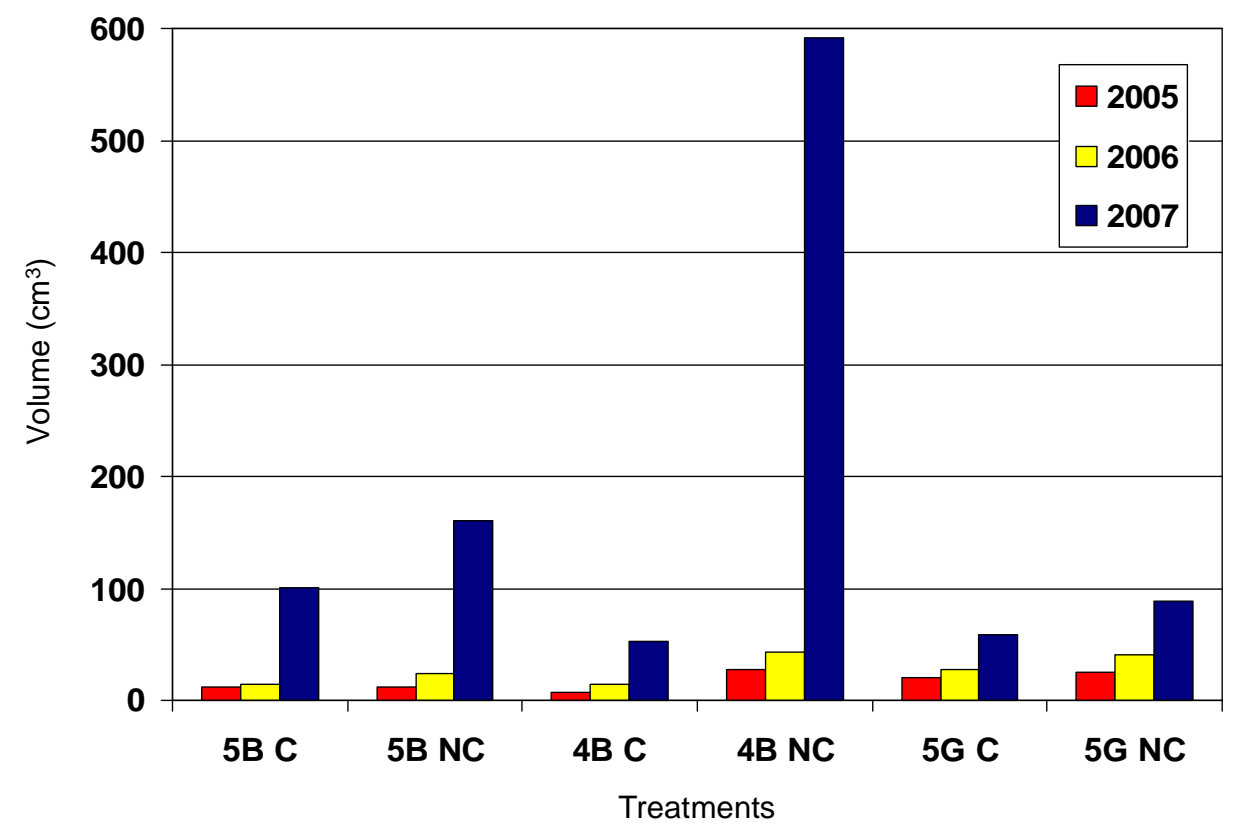

Figure 10A. Average volume of Tulip poplar across all treatments after three growing seasons at Catenary Coal Mine, Kanawha County, West Virginia.

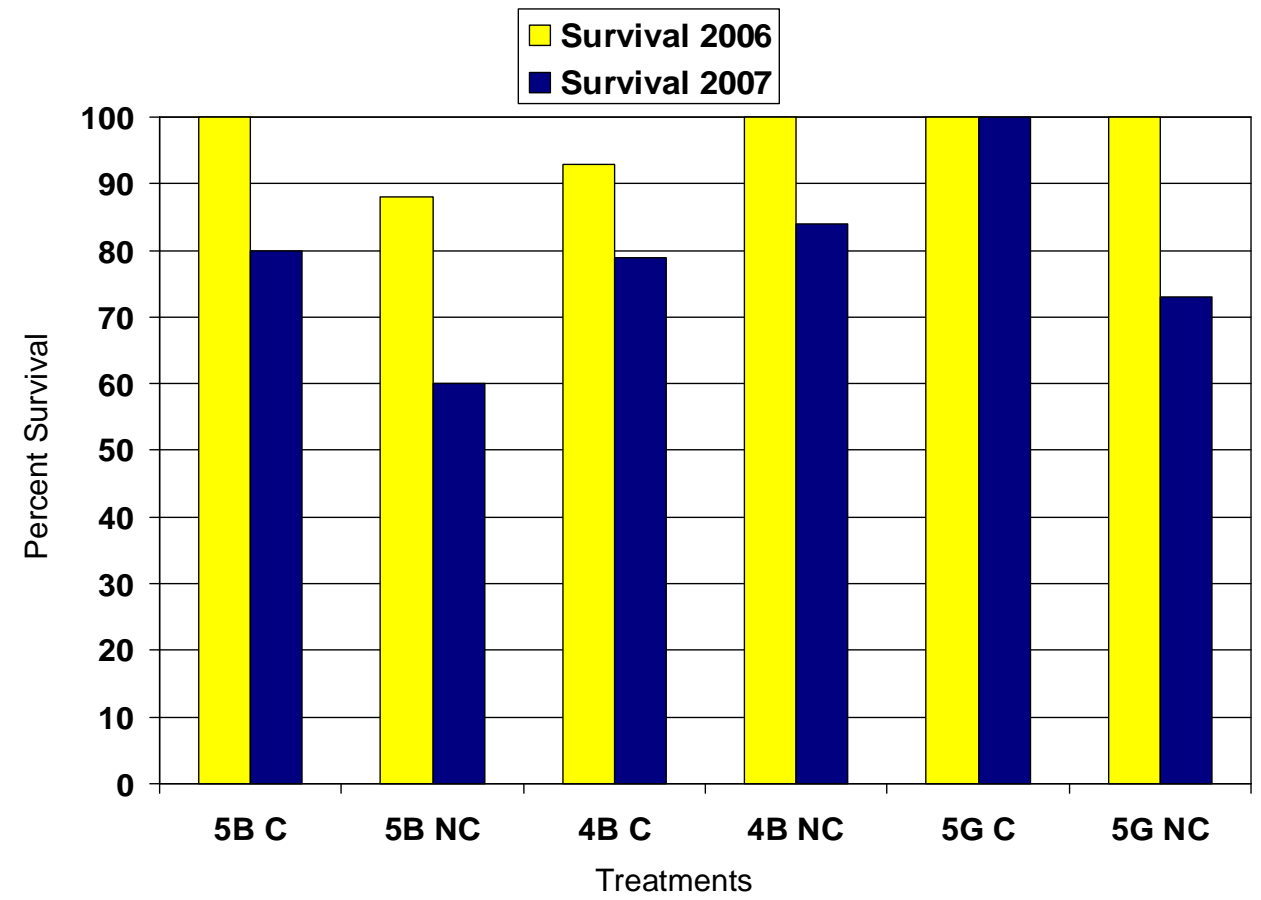

Figure 10B. Average survival of Tulip poplar across all treatments after three growing seasons at Catenary Coal Mine, Kanawha County, West Virginia. 


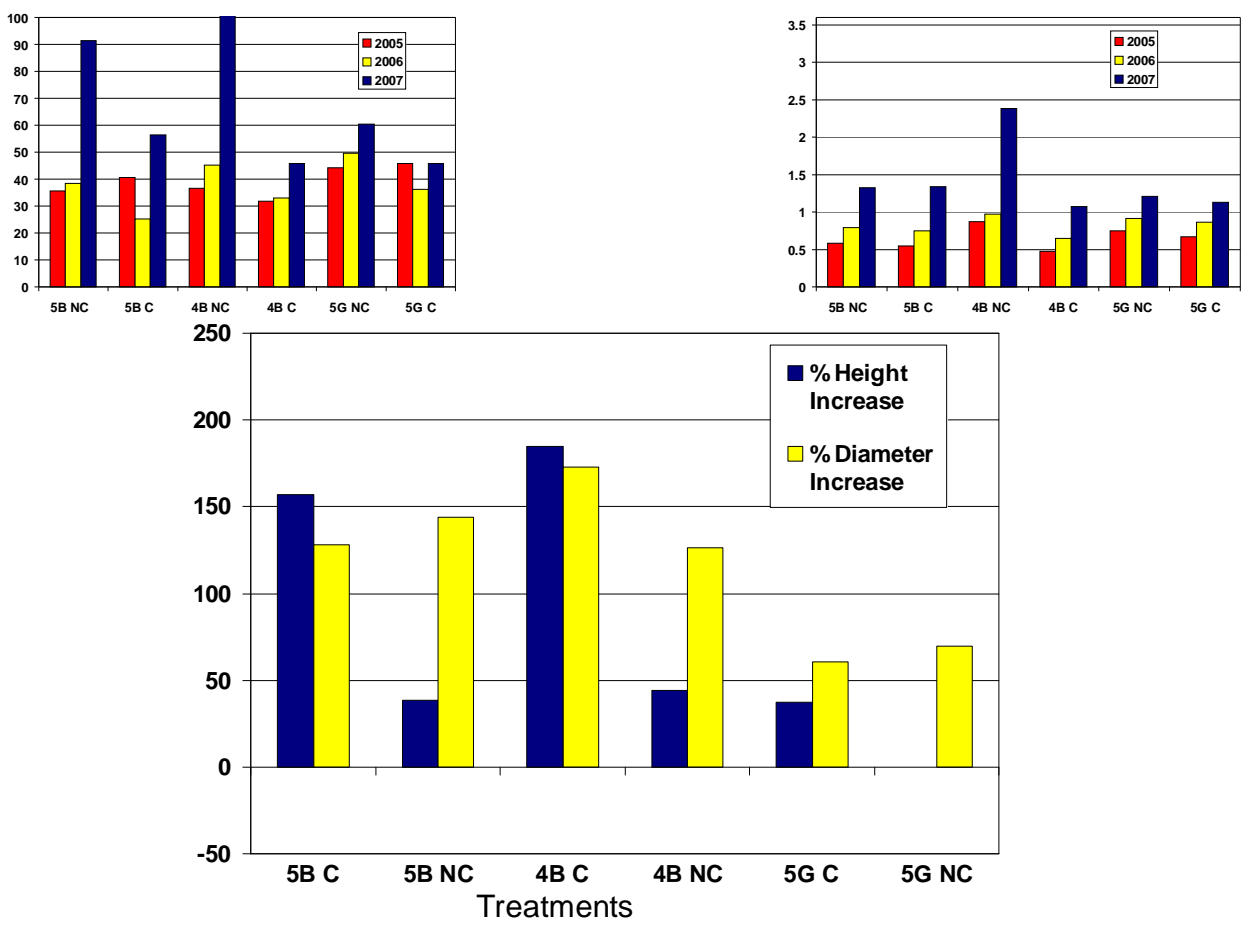

Figure 10C. Average height, diameter, and percent increase of Tulip poplar across all treatments after three growing seasons at Catenary Coal Mine, Kanawha County, West Virginia. 
Another study showed similar results for Tulip poplar planted in spoil banks. In this experiment (DenUyl, 1962), Tulip poplar also had the lowest survival of the 10 planted species examined. Neither growth, nor direct diameter or height measurements were taken in this experiment, so growth could not be compared (DenUyl, 1962). Tulip poplar is a prolific sprouter and sprouts usually exceed the seedling in growth rate. These sprouts, which come from around the root collar, are even less susceptible to decay (Hicks, 1998). Once established, Tulip poplar is a vigorous grower and can sustain height growth of nearly $.46 \mathrm{~m} / \mathrm{yr}$ and diameter growth of $.64 \mathrm{~cm} / \mathrm{yr}$ on good sites (Beck and Della-Bianca, 1970). A concern about Tulip poplar is outbreaks of insects. Outbreaks of the Yellow poplar weevil have been reported in West Virginia five out of the last twenty years (Hicks and Mudrick, 1994).

White ash is the most common ash in North America, and its wood is known for being hard and difficult to break under stress. It requires moist and fertile conditions and prefers high levels of calcium (Schlesinger, 1990; Hicks, 1998). It is a slow growing species, and may take up to 15 years to reach a height of $1.5 \mathrm{~m}$. White ash response seemed to be the most inconsistent of all the species in our study. Its average survival (79\%) was slightly higher than the average survival across all species (78\%) (Figure 11C11C). Its average volume was $107.5 \mathrm{~cm}^{3}$, only slightly higher than the median volume of $95.0 \mathrm{~cm}^{3}$ for all species. However, in percent increase it was second in both percent height and percent diameter increase behind Black locust. White ash's root systems in forest soils grow deep, however, when in rocky shallow soils their root systems are shallow and spreading. 


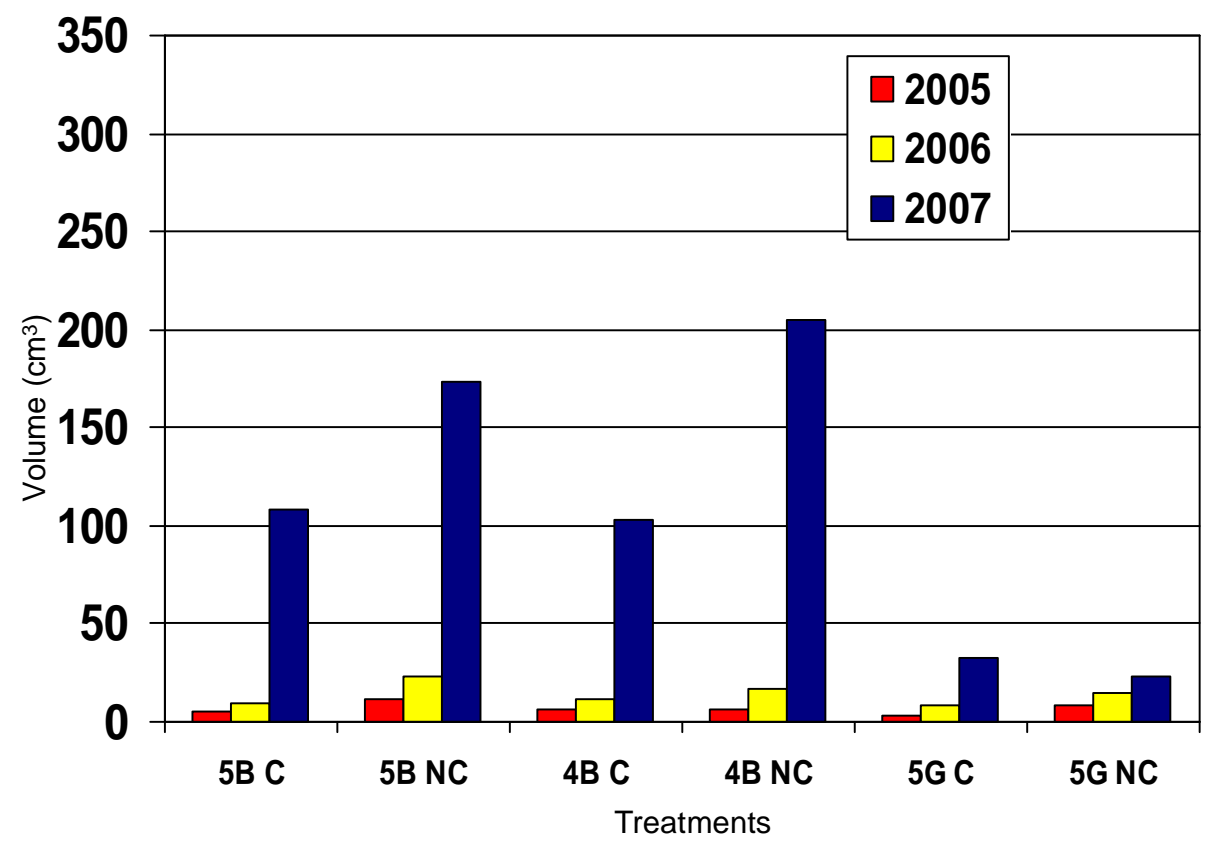

Figure 11A. Average volume of White ash across all treatments after three growing seasons at Catenary Coal Mine, Kanawha County, West Virginia.

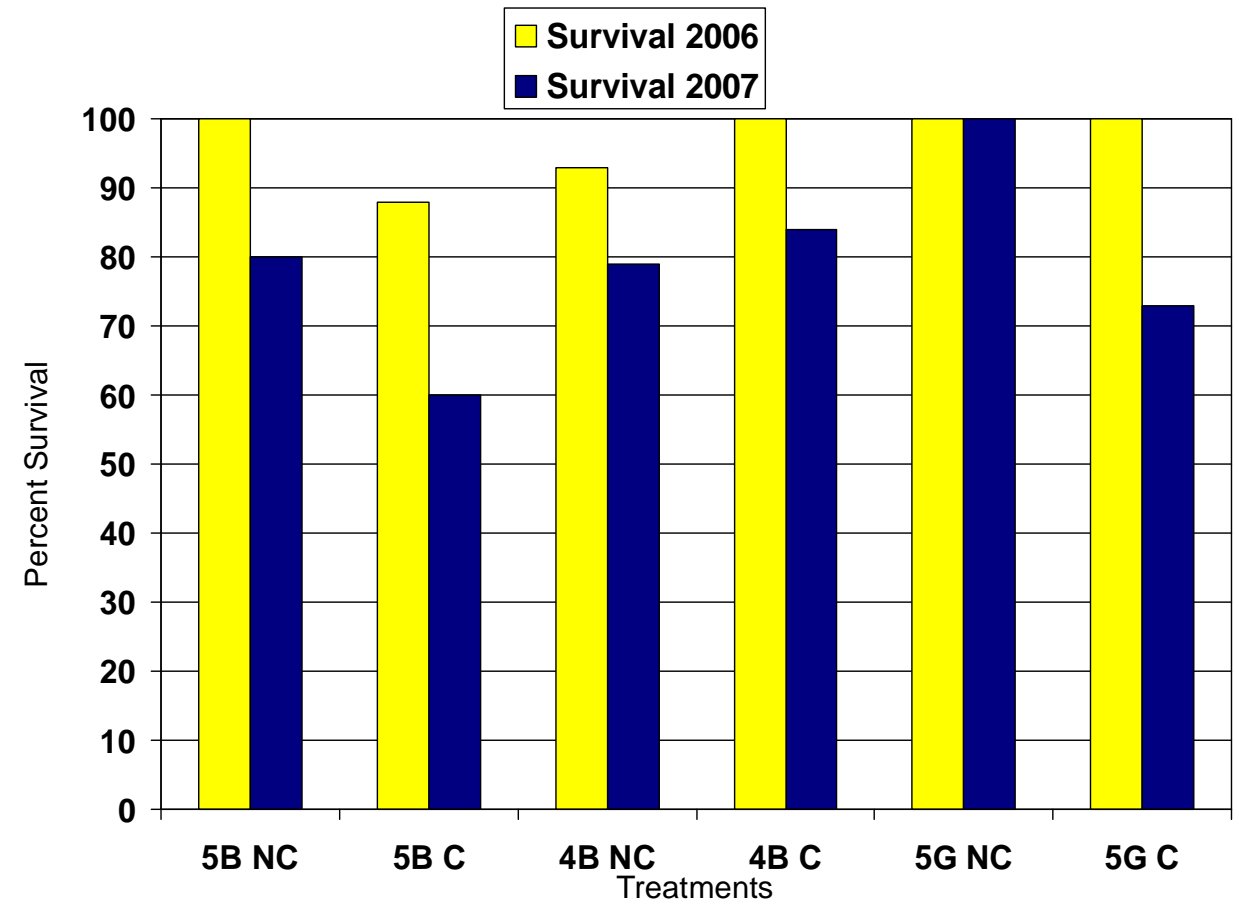

Figure 11B. Average volume of White ash across all treatments after three growing seasons at Catenary Coal Mine, Kanawha County, West Virginia. 


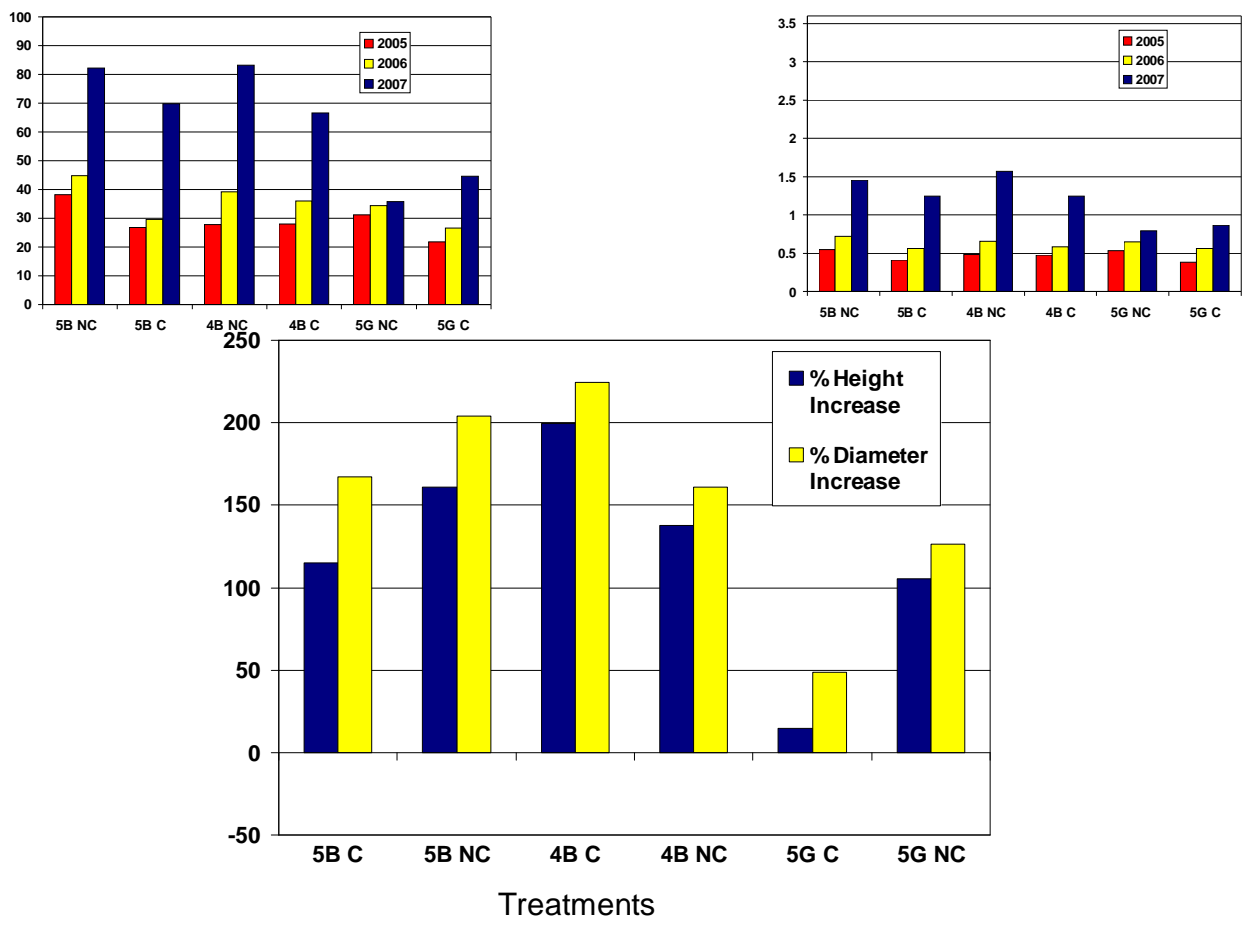

Figure 11C. Average height, diameter, and percent increase of White ash across all treatments after three growing seasons at Catenary Coal Mine, Kanawha County, West Virginia. 
Ashes are early-successional species well adapted to reclaimed mine environments. Zeleznik and Skousen (1996) as well as Skousen et al. (2006) found that White ash had the best survival rates in their studies. Harlow and Harrar (1968) also write that ashes are known to be very tolerant at the seedling stage as they are abundant in a forest's understory. A concern for this species is the Emerald Ash Borer, which is spreading throughout the region and was found in Nicholas County of West Virginia in 2007.

\section{Tree volume and percent change by substrate}

Tree volume across all species by substrate showed that gray sandstone (average of $44.4 \mathrm{~cm}^{3}$ ) was significantly lagging behind brown sandstone (average of $218.3 \mathrm{~cm}^{3}$ ) when all species were considered. When non-log transformed, the volume data show no significant differences between treatments. However, after log transforming, the results are as follows: the 1.2-m brown sandstone uncompacted $\left(308.4 \mathrm{~cm}^{3}\right)$, and the $1.5-\mathrm{m}$ brown sandstone compact $\left(211.7 \mathrm{~cm}^{3}\right)$ and uncompacted $\left(128.3 \mathrm{~cm}^{3}\right)$ were significantly greater than the $1.5-\mathrm{m}$ gray sandstone compact $\left(54.6 \mathrm{~cm}^{3}\right)$ and uncompacted $\left(34.4 \mathrm{~cm}^{3}\right)$. The 1.2-m brown sandstone compact plot $\left(236.5 \mathrm{~cm}^{3}\right)$ was not significantly higher than the $1.5-\mathrm{m}$ gray sandstone compact $\left(54.6 \mathrm{~cm}^{3}\right)$, but was significantly higher than the uncompacted side of the 1.5-m gray sandstone plot $\left(34.4 \mathrm{~cm}^{3}\right)$ (Table 5).

When looking at percent change by substrate, brown sandstone outperformed gray sandstone in both height and diameter (Table 4). The average percent height increase across all species on all brown sandstone plots was $86 \%$ compared to gray sandstone's $17 \%$. The same trend continued for the percent diameter increase, which was $165 \%$ on the brown sandstone plots, and only $62 \%$ on gray sandstone. 
A somewhat contradictory effect resulted from comparing substrate depth, which showed the $1.2-\mathrm{m}$ plots had significantly greater volume $\left(272.4 \mathrm{~cm}^{3}\right)$ than the $1.5-\mathrm{m}$ plots $\left(104.3 \mathrm{~cm}^{3}\right)$. This result would surprise some at first glance, however, since only three growing seasons have passed since planting, the root systems of these trees have not fully taken advantage of the depth of the planting substrate. This result is more likely tied to the fact that six of the eleven species planted had their greatest amount of growth on the 1.2-m brown plot.

With volume data not log transformed, Red oak's volume was significantly better on brown sandstone $\left(114.7 \mathrm{~cm}^{3}\right)$ as compared to gray sandstone $\left(26.2 \mathrm{~cm}^{3}\right)$. Volume data were then log transformed to make the data more normalized to account for the six extreme outliers. This resulted in a significant difference in volume of three species, Red oak, Dogwood, and Black locust. Red oak once again performed significantly better in brown sandstone, as did Dogwood and Black locust. Although the effects of compaction have been well documented to have a negative effect on tree growth, the average volume across all species for all non-compacted sites after three growing seasons was $153.2 \mathrm{~cm}^{3}$, whereas compacted sites had a volume of $167.3 \mathrm{~cm}^{3}$. These differences were not significant at the $\mathrm{p}<.05$ level. Compaction did not have an effect on tree volume on any species during this three-year study. When each species overall volume was compared to the rest of the species, Black locust was the only one that was significantly different from the other trees (Tables 6 and 7, Figure 12). 
Table 6. Degrees of freedom, sum of squares, $F$ value, and probabilities of survival and growth of 11 planted species at Catenary Coal, Kanawha County, West Virginia. **Interaction degrees of freedom, least squares, and probability.

\begin{tabular}{|c|c|c|c|c|}
\hline Category & DF & Type I SS & F Value & $\operatorname{Pr}>F$ \\
\hline \multicolumn{5}{|l|}{$\begin{array}{l}\text { Species } \\
\text { Spes }\end{array}$} \\
\hline Survival & 10 & .732 & 2.1 & .0421 \\
\hline Volume & 10 & 21427.3 & 7.3 & $<.0001$ \\
\hline \multicolumn{5}{|l|}{ Substrate } \\
\hline Survival & 5 & .679 & 4.11 & .0028 \\
\hline Volume (log) & 5 & 31.06 & 6.06 & .0001 \\
\hline \multicolumn{5}{|l|}{ Brown v. Gray } \\
\hline Survival & 1 & .1978 & 5.97 & .0175 \\
\hline Volume & 1 & 26.37 & 25.7 & $<.0001$ \\
\hline \multicolumn{5}{|c|}{ Comp. v. Non-comp. } \\
\hline Survival & 1 & .0072 & .22 & .6424 \\
\hline Volume & 1 & .4784 & .47 & .4974 \\
\hline \multicolumn{5}{|l|}{$1.2 \mathrm{~m} \mathrm{v} .1 .5 \mathrm{~m}$} \\
\hline Survival & 1 & .0347 & 1.05 & .3102 \\
\hline Volume & 1 & 5.306 & 5.17 & .0266 \\
\hline Interactions $* *$ & $\mathrm{DF}$ & LS mean & & $\operatorname{Pr}>|\mathrm{t}|$ \\
\hline \multicolumn{5}{|l|}{ Survival } \\
\hline 1.5m Brown NC & 5 & .754 & & $<.0001$ \\
\hline 1.5m Brown C & 5 & .882 & & $<.0001$ \\
\hline $1.2 \mathrm{~m}$ Brown NC & 5 & .763 & & $<.0001$ \\
\hline 1.2m Brown C & 5 & .589 & & $<.0001$ \\
\hline 1.5m Gray NC & 5 & .871 & & $<.0001$ \\
\hline 1.5m Gray C & 5 & .855 & & $<.0001$ \\
\hline \multicolumn{5}{|l|}{ Volume } \\
\hline 1.5m Brown NC & 5 & 1.585 & & $<.0001$ \\
\hline 1.5m Brown $\mathrm{C}$ & 5 & 2.389 & & $<.0001$ \\
\hline 1.2m Brown NC & 5 & 2.007 & & $<.0001$ \\
\hline 1.2m Brown C & 5 & 2.151 & & $<.0001$ \\
\hline 1.5m Gray NC & 5 & .903 & & .0045 \\
\hline 1.5m Gray C & 5 & .469 & & .1297 \\
\hline
\end{tabular}


Table 7. Average values and significant differences for survival and volume of $\mathbf{1 1}$ planted species through three growing seasons at Catenary Coal, Kanawha County, West Virginia.

\begin{tabular}{lcr}
\hline & Survival & Volume \\
\hline Species & $---\%---$ & $\left(\mathrm{cm}^{3}\right)$ \\
BC & $70 \mathrm{c}$ & \\
BL & $100 \mathrm{a}$ & $170.8 \mathrm{~b}$ \\
CNO & $76 \mathrm{bc}$ & $792.0 \mathrm{a}$ \\
DW & $83 \mathrm{abc}$ & $62.1 \mathrm{~b}$ \\
RB & $92 \mathrm{ab}$ & $139.6 \mathrm{~b}$ \\
RO & $80 \mathrm{abc}$ & $94.9 \mathrm{~b}$ \\
SM & $83 \mathrm{abc}$ & $84.9 \mathrm{~b}$ \\
TP & $65 \mathrm{c}$ & $43.2 \mathrm{~b}$ \\
WA & $79 \mathrm{abc}$ & $175.2 \mathrm{~b}$ \\
WO & $70 \mathrm{c}$ & $107.5 \mathrm{~b}$ \\
WP & $65 \mathrm{c}$ & $58.0 \mathrm{~b}$ \\
& & $35.7 \mathrm{~b}$
\end{tabular}

Substrate

$\begin{array}{lcc}\text { Gray } & 86 \mathrm{a} & 44.5 \mathrm{~b} \\ \text { Brown } & 74 \mathrm{~b} & 218.3 \mathrm{a} \\ & & \\ \text { Compact } & 79 \mathrm{a} & 167.6 \mathrm{a} \\ \text { Non-compact } & 78 \mathrm{a} & 153.2 \mathrm{a} \\ & & \\ 1.2 \mathrm{~m} & 82 \mathrm{a} & 272.4 \mathrm{a} \\ 1.5 \mathrm{~m} & 77 \mathrm{a} & 104.3 \mathrm{~b} \\ & & \\ \text { tions } & & 128.3 \mathrm{ab} \\ \mathrm{m} \text { Brown NC } & 59 \mathrm{~b} & 211.7 \mathrm{a} \\ \mathrm{m} \text { Brown C } & 75 \mathrm{a} & 308.4 \mathrm{a} \\ \mathrm{m} \text { Brown NC } & 88 \mathrm{a} & 236.5 \mathrm{a} \\ \mathrm{m} \text { Brown C } & 76 \mathrm{a} & 34.4 \mathrm{c} \\ \mathrm{m} \text { Gray NC } & 86 \mathrm{a} & 54.6 \mathrm{bc} \\ \text { m Gray C } & 87 \mathrm{a} & \end{array}$




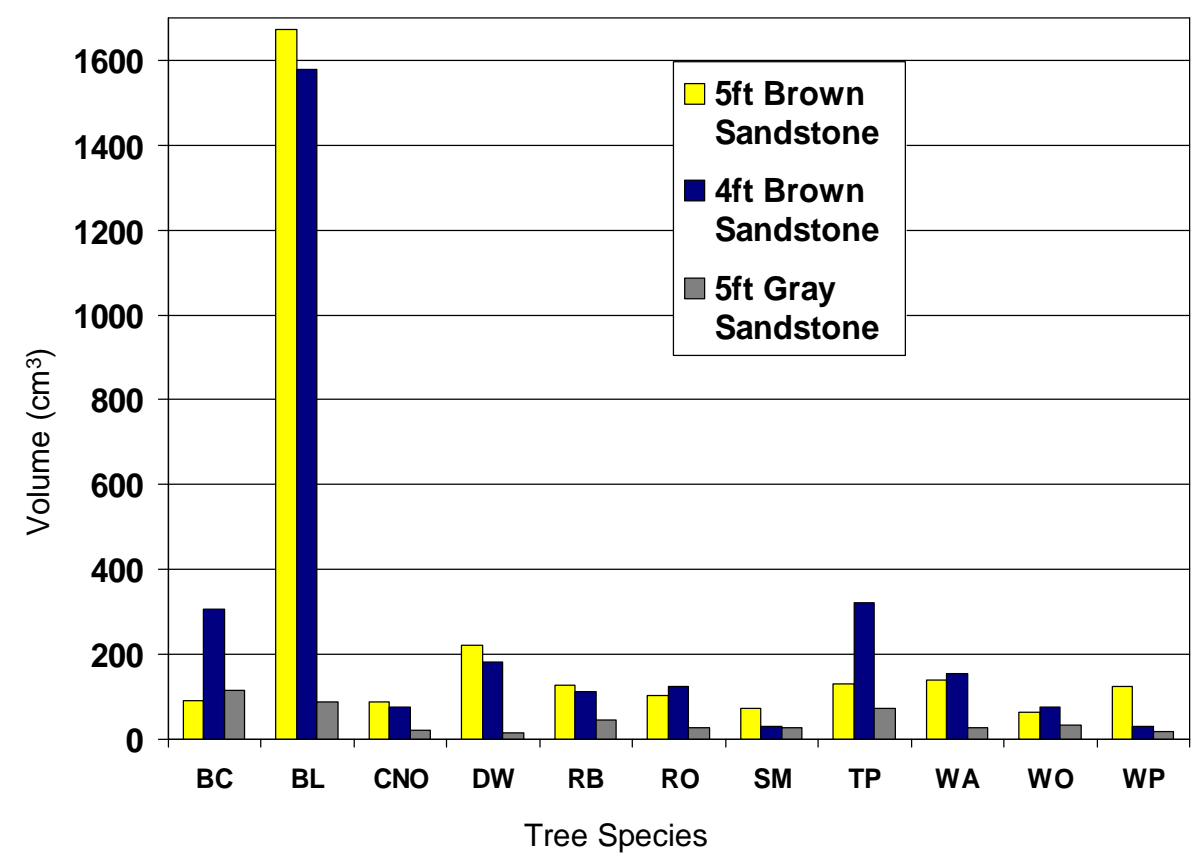

Figure 12. Volume of eleven planted species across all treatments after three growing season at Catenary Coal, Kanawha County, West Virginia. See Table 1 for tree species abbreviations.

\section{Survival}

Overall survival by species varied from $65 \%$ for Tulip poplar and White pine to 100\% for Black locust (Table 8). Again, Black locust's survival and growth potential has been well documented on minesoils, so this high survival number is not surprising. White pine has also been extensively planted on mine spoils, and has largely been successful. However, White pine has been shown not to do well during the initial few years after planting (Harlow and Harrar, 1968; Hicks, 1998). Because of slow growth during the first few years after planting, early evaluations of White pine plantings may be misleading. Based on survival and growth, White pine would be rated as the third best of the conifers plated in large quantities on spoils in West Virginia (Brown, 1962). 
Table 8. Percent survival of 11 planted species of tree on three soil mediums and two compaction treatments after three years at Catenary's Mine in Kanawha County, West Virginia.

\begin{tabular}{lccccccc}
\hline & \multicolumn{8}{c}{ Treatments $^{1}$} \\
& 5B NC & 5B C & 4B NC & 4B C & 5G NC & 5G C & Avg. \\
\hline Black Cherry & 0 & 50 & 100 & 67 & 100 & 100 & 69 \\
Black Locust & 100 & 100 & 100 & 100 & 100 & 100 & 100 \\
Chestnut Oak & 60 & 78 & 79 & 100 & 83 & 56 & 76 \\
Dogwood & 83 & 67 & 86 & 100 & 60 & 100 & 83 \\
Redbud & 67 & 100 & 100 & 83 & 100 & 100 & 92 \\
Red Oak & 70 & 70 & 88 & 80 & 94 & 79 & 80 \\
Sugar Maple & 50 & 78 & 93 & 75 & 100 & 100 & 83 \\
Tulip Poplar & 60 & 55 & 83 & 25 & 91 & 78 & 65 \\
White Ash & 60 & 80 & 84 & 79 & 73 & 100 & 79 \\
White Oak & 54 & 71 & 95 & 50 & 73 & 75 & 70 \\
White Pine & 44 & 75 & 63 & 71 & 67 & 71 & 65 \\
& & & & & & & \\
Avg. & 67 & 75 & 88 & 75 & 86 & 87 & \\
\hline
\end{tabular}

${ }^{\mathrm{T}}$ See Table 3 for treatment abbreviations

Tulip poplar has also been widely planted on mine soils and well studied. Most studies indicate that Tulip poplar does better on slightly acidic sandstone spoils on north and east facing slopes or on the toe slope where soil moisture is greater. Here they were planted indiscriminately across all aspects and slope positions.

During the initial years after seed germination, White oak shoots grow slowly while they build extensive root systems (Harlow and Harrar, 1968). This is demonstrated by White oak having the second lowest above ground growth $\left(58.1 \mathrm{~cm}^{3}\right)$ of all species across all treatments next to White pine. Native hardwoods generally grow best on slightly acidic spoils (pH between 5.0 and 6.8) with loamy texture, especially sandy loam which are generally generated from brown or gray sandstone (Burger et al., 2005b). While all plots were constructed of sandstone, the gray sandstone was much more alkaline (data for soils shown in next chapter). Brown sandstones $\mathrm{pH}$ ranged from 4.36.5 while gray sandstone's $\mathrm{pH}$ was 7.5-8.0. However, gray sandstone had higher 
survivals for all species except for two (Chestnut oak and Dogwood). The brown sandstone had higher percent fines so therefore it might show a higher water holding capacity and higher moisture content. It was also noted during the data collection that the brown sandstone appeared to have a higher moisture content than the gray at every visit.

Overall survival by treatment varied greatly from $59 \%$ on $1.5-\mathrm{m}$ brown noncompact to $88 \%$ on $1.2-\mathrm{m}$ brown non-compact. The $1.5-\mathrm{m}$ brown non-compact treatment was the only treatment significantly different than the rest. While the $1.5-\mathrm{m}$ plots are supposed to support tree growth better because of the greater rooting depth, there has not been enough time for this to be a factor. However, without rooting depth as a limiting factor, they should both be effectively non-compacted brown sandstone areas yet the survival varied by almost $30 \%$ over three years.

Survival on the compact vs. the non-compact sites did not show any significant differences for any of the eleven species planted during the study period. Compaction due to grading should reduce soil moisture and aeration, impede root penetration, and negatively affect many other soil characteristics (Hatchell et al., 1970). However, in this study there was only a small difference in overall survival across all species and substrates during this study period (79\% compact and 78\% non-compact) (Figure 13). 


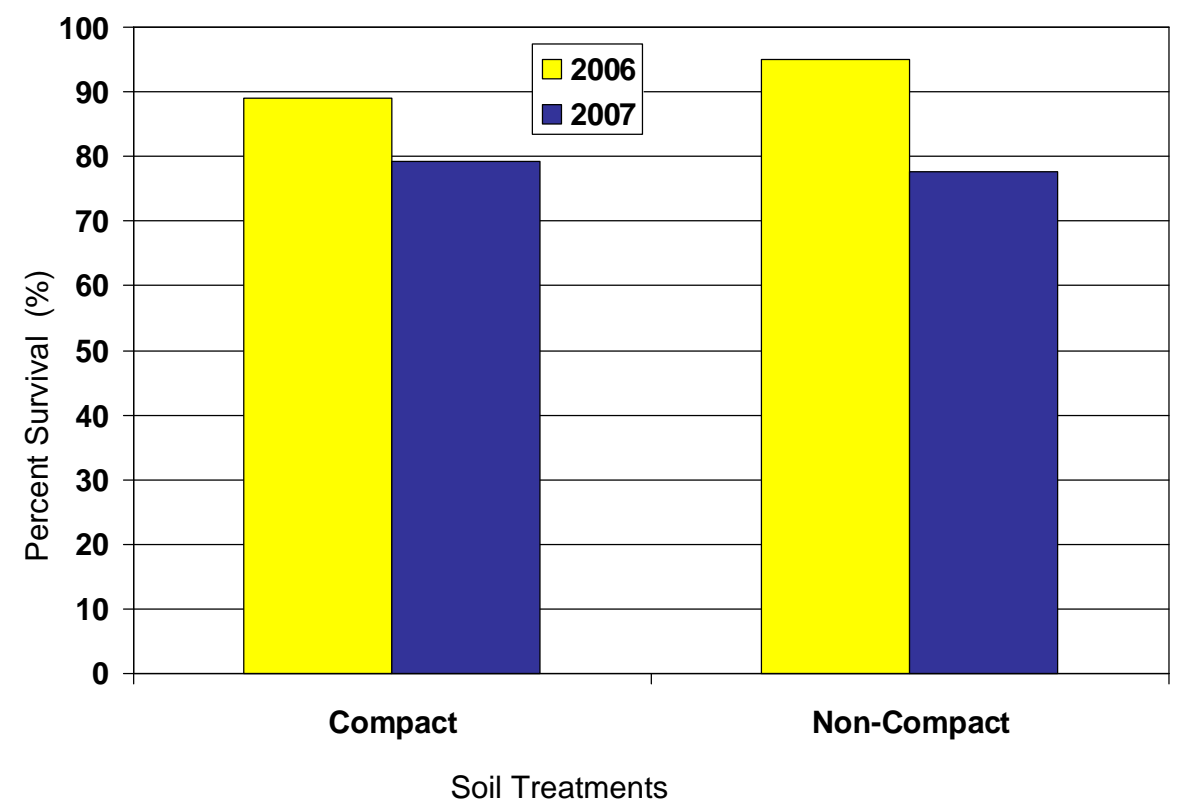

Figure 13. Percent survival of all eleven species on compact vs. non-compact areas after three growing seasons at Catenary Coal Mine, Kanawha County, West Virginia.

\section{Conclusions}

After the first three years only Black locust had significantly greater volume than the other ten trees planted (Tables 6 and 7). The data also show that trees growing in brown sandstone had significantly greater volume than those growing in gray sandstone. The interaction of substrate type (brown or gray), compaction (compacted or uncompacted) and depth (1.2-m or 1.5-m) showed that none of the brown sandstone treatments were significantly different in tree volume from each other. However, all but one of the brown sandstone treatments were significantly higher in tree volume than both the gray sandstone treatments. The only brown sandstone treatment that was not significantly different was the 1.5-m brown sandstone uncompacted, and it was not significantly different from the 1.5-m gray sandstone compact (Tables 6 and 7). 
Tree survival varied between $88 \%$ and $59 \%$ across these treatments, with the 1.5 m brown sandstone uncompacted treatment (59\%) having significantly lower survival that all other treatments. 


\section{Chapter 4.}

\section{Soil Physical and Chemical Properties Important to Tree Survival and Growth}

\section{Introduction:}

The selection and placement of overburden used for forestry reclamation is of critical importance to ensure good tree survival and growth. The proper selection of substrate is important because it will affect $\mathrm{pH}$, electrical conductivity, percent fines and rock, texture, and nutrients. Rodrigue and Burger (2004) found the most important soil factors for tree growth on reclaimed mine sites were base saturation, coarse fragments, available water, electrical conductivity and C-horizon porosity. Some materials may need to be mixed with other layers to achieve desirable properties, while other materials can be used by themselves and stockpiled for a time before placement.

After the proper material has been selected it must then be placed using methods which do not overly compact the area. Ideally materials are placed and then graded lightly so that compaction does not occur. There are several methods used to lessen compaction during placement as well as reducing compaction once an area has already been placed and tracked in. One method which is aimed at reducing compaction during construction is the top-off method. This method requires piles of substrate to be closely situated after they are dumped and then a small dozer makes one or two passes to knock

off the tops of the piles and push them into the low spots between piles (Figures 14A and 14B). 


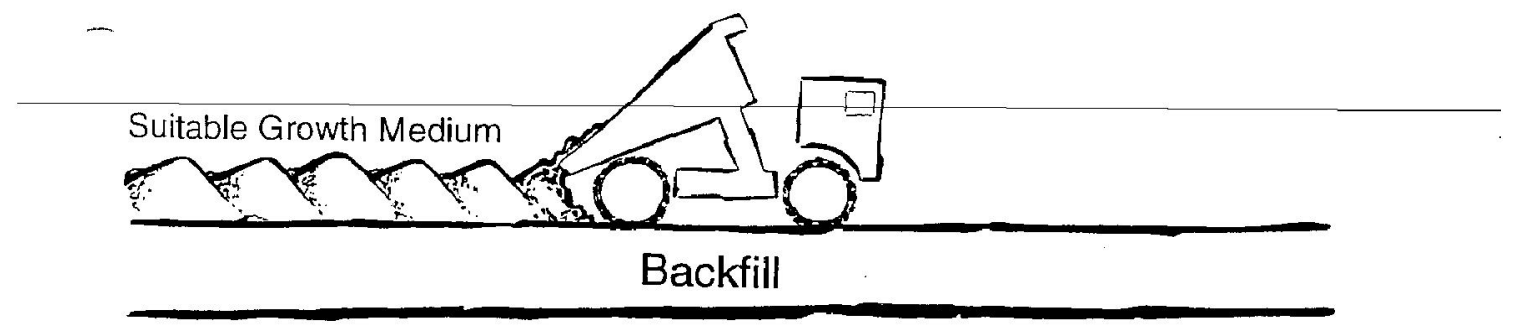

Figure 14A. Backfilling and end-dumping by trucks.

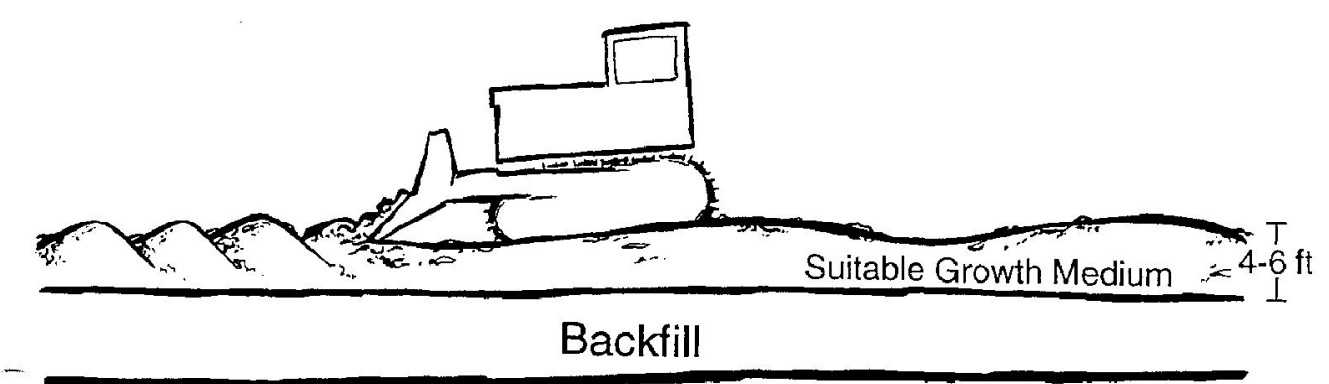

Figure 14B. "Topping off" piles after backfill with one or two passes from a bulldozer. (Figures are taken from Sweigard et al., 2007)

This placement of overburden reduces compaction and requires much less grading on the part of the mine operator. It is becoming well known within the mining industry that tree reclamation requires deep (at least $1.2 \mathrm{~m}$ ), loose mine spoils (Burger et al., 2005b).

If the goal of the operator is to alleviate compaction problems after reclamation is complete (as with AML or where reclaimed pastures are to be planted with trees), ripping or deep plowing have been widely used methods (Ashby, 1997; Ashby 1996b). Using single, double, or triple shank rippers, bulldozers can rip and cross rip areas to reduce compaction. Trees are then generally planted in the cross rips where bulk density/compaction is the lowest. However, once again it is best to control compaction of the substrate during construction of the planting media rather than reducing it after reclamation. 
The $\mathrm{pH}$ of the soil affects many aspects of tree growth and survival. Not only do different species of trees have different $\mathrm{pH}$ ranges where they have optimal growth and survival, but the $\mathrm{pH}$ also affects the amount of plant available nutrients (Klock et al., 1984). For example, phosphorus is most readily available at a $\mathrm{pH}$ range of 6.0-7.5. Below a pH of 6.0, phosphorus commonly creates insoluble complexes with iron, aluminum, and manganese. Above a $\mathrm{pH}$ of 7.0, phosphorus may bind with calcium and become less available for plants (Klock et al., 1984). The $\mathrm{pH}$ of a soil is mainly derived from its parent material. In the case of forestry reclamation on surface mined lands, the parent material is derived from the "best available material" which usually consists of sandstone in both the oxidized and unoxidized form (Burger et al., 2005b). Oxidized, or brown, sandstone has undergone some weathering and leaching, whereas unoxidized, or gray, sandstone is from deeper within the geologic column and has not undergone any weathering or leaching. The $\mathrm{pH}$ of these two types of sandstone differs greatly. While oxidized brown sandstone has a $\mathrm{pH}$ range of 4.5-6.0, the unoxidized gray sandstone generally ranges from 6.0-8.5 (Haering et al., 2004).

Haering et al. (2004) found that the $\mathrm{pH}$ of a mine soil composed of unoxidized gray sandstone in southwestern Virginia decreased significantly after one year, however, three years later the $\mathrm{pH}$ was significantly higher. This was attributed to the addition of $\mathrm{N}$ fertilizers and organic matter accumulation causing the $\mathrm{pH}$ to fall the first year. Later, as the acid producing reactions slowed, the overburden continued to weather which exposed and released more carbonates causing the $\mathrm{pH}$ to rise again. The same study also showed that oxidized brown sandstone had no significant change in $\mathrm{pH}$ over the same time span. 
The percent fine $(<2 \mathrm{~mm})$ and coarse fragments $(>2 \mathrm{~mm})$ of a soil affect nutrient availability. Smaller size particles $(<2 \mathrm{~mm})$ are more reactive than larger size particles (>2mm) (Mortland and Kemper, 1965). A mine soil created from the weathering of blasted rock is dominated by coarse fragments that can constitute more than $70 \%$ of the soil (Ciolkosz et al., 1985; Pedersen et al., 1980; Thurman and Sencindiver, 1986). They also generally have low clay content and are quite variable in nutrient concentrations (Roberts et al., 1988). Even though soil analyses for chemical and physical attributes are conducted on the fine portion of the soil, the coarse fraction affects water holding capacity, rooting depth, and many other soil properties (Haering et al., 1993). The particle size distribution of a mine soil, especially the fine $(<2 \mathrm{~mm})$ fraction, is largely a function of parent material (Wood and Pettry, 1989).

Overburden materials located near the top of the geologic column have been partially weathered in place. These materials are usually more oxidized, leached, and acidic (Haering et al., 2004). This zone of weathering extends 6-12 m below the surface in West Virginia, and can be identified by soil color chromas $\geq 3$ (Haering et al., 2004). As more coal is being mined, the ability to go deeper into the geologic column has created more minesoils composed of material under these partially weathered strata. Here the overburden comes from deep in the geologic column and the resulting spoil materials frequently consist of unweathered and unoxidized materials which usually have an initial chroma of $\leq 2.5$, attributed mostly to it being reduced in nature (Haering et al., 2004).

As geologic units are leached in place, some of their nutrients are released and either deposited in lower strata or leached out of the geologic column all together. As 
these materials are placed as a planting substrate, weathering continues as nutrients are leached into and through the soil. The ability of a mine spoil substrate to provide sufficient nutrients as they continue to break down and weather has not been well documented. A fertility experiment was designed to examine nutrient leaching from brown (weathered) and gray (unweathered) sandstones. The fact that brown (weathered) sandstone has been already leached in place should lead to lower concentrations of nutrients. The gray (unweathered) sandstone by contrast has not been exposed to any leaching until it was placed as the growing media. These sandstones should have more nutrients to release as they continue to weather and breakdown. If these gray materials do in fact have more nutrients to leach then they could be a more productive planting substrate.

Since numerous methods are available to conduct soil extractions, two accepted methods were used. In this fertility experiment, four macro nutrients were analyzed over a series of extractions by two different methods on two different-sized soil fractions.

\section{Materials and Methods}

\section{Soil Collection}

Soil samples were collected once a year each year of the study (2005-2007). Samples were taken from five random locations along transects on each treatment (transects described in Chapter 1). The sample came from the top $15 \mathrm{~cm}$ of substrate and was bagged and labeled. Samples used in the fertility experiment were taken in 2007.

\section{Percent Fines and Percent Sandstone}

Percent fines and percent sandstone were determined by taking five random samples (approximately $2 \mathrm{~kg}$ ) from each treatment. Each sample was dried, weighed and 
then sieved through a US standard $<2 \mathrm{~mm}$ sieve. The "percent fines" was calculated using the weight of material which passed through the sieve and dividing it by total weight of the sample. Percent sandstone was determined by collecting everything that did not pass through the sieve and then removing other rock fragments that were not sandstone (mostly shales and pieces of coal and wood). This material was then weighed and divided by total weight of sample.

\section{Chemical Analysis}

The $<2 \mathrm{~mm}$ samples were extracted with a Mehlich 1 extract, which is composed of $0.05 \mathrm{~N} \mathrm{HCl}$ and $0.025 \mathrm{~N} \mathrm{H}_{2} \mathrm{SO}_{4}$. The solution after passing through the soil was analyzed with a Perkin Elmer Plasma 400 emission spectrometer for aluminum, iron, manganese, calcium, magnesium, phosphorus, and potassium (Mehlich, 1953).

Soil $\mathrm{pH}$ was determined by a 1:1 mixture with deionized distilled water. A Beckman $43 \mathrm{pH}$ meter was then used to determine the $\mathrm{pH}$ of the mixture. Soluble salts, as measured by electrical conductivity, was determined with a 2:1 mixture and determined on a Microprocessor Conductivity Meter LF 3000 (Bower and Wilcox, 1965).

\section{Soil Fertility Experiment}

Dried samples of weathered brown sandstone and unweathered gray sandstone were sieved to separate the clay and silt size fraction from the sand size fraction. This was done by sieving the sample through the US standard \#80<2mm sieve. Everything

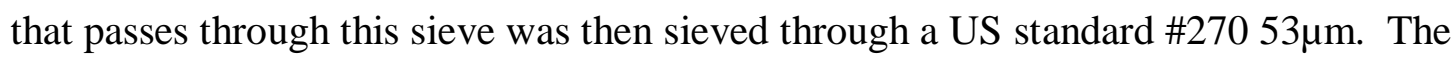
fraction that passed through the \#270 sieve was considered the silt and clay-sized fraction, and the portion that stays on top of the \#270 sieve was considered the sand-sized fraction. These two fractions were separated because sand-sized particles are supposed to 
have little nutrient-holding capacity compared to silt and clay sized particles (Mortland and Kemper, 1965).

Two extraction methods were tested. First, a modification of the standard Morgan method (Morgan, 1941) was used. The standard Morgan method was conducted using 10 $\mathrm{cm}^{3}$ of soil and $50 \mathrm{~mL}$ of extract. The procedure calls for shaking the soil and extract for 15 minutes at 180 oscillations per minute. After shaking, the soil and solution were filtered through a $0.8 \mu \mathrm{m}$ filter (Whatman 42 filter paper) and the filtrate was analyzed. After each filtration the sample was allowed to dry on the filter paper, then removed and weighed. The amount of extractant added for the next extraction was then adjusted to keep the ratio of soil to extractant consistent with the starting (1:5) ratio. The same sample was then prepared, shaken, and filtered in the same way as described. This process was repeated four times, at which point 3 of the 4 nutrients examined were nondetectable.

The second method used an extractor apparatus. The same amount of sample (10 $\mathrm{cm}^{3}$ ) was placed in an extraction tube on top of a cotton pulp filter and the same amount of Morgan extract $(50 \mathrm{~mL})$ was put in the reservoir tube which was attached to the top of the extraction tube. The extractor slowly pulled the extract through the sample over 12 hours and into a collection tube. This allowed the soil sample to remain in the tube and could be leached repeatedly by simply adding more extract to the reservoir tube. This process was repeated four times and the solution was analyzed for the same elements after each extraction.

After extraction/filtering each sample was diluted to a 1:10 ratio (1 part extract, 10 parts distilled water) so heavy salt accumulation wouldn't occur in the ICP during 
analysis. Samples were then analyzed by ICP for phosphorus, potassium, calcium, and magnesium.

\section{Results and Discussion}

Elemental analysis showed only a few significant differences among substrates for the elements (Tables 9 and 10). Aluminum was significantly higher on brown sandstone as compared to gray sandstone. Phosphorus and iron were significantly greater on gray sandstone.

Analysis of soil parameters showed significant differences in $\mathrm{pH}$, but not between percent fines or percent sandstone (Table 11). The $\mathrm{pH}$ of the mine spoils fluctuated through the three years of the study. There has been some conflicting research on the subject. Most mine spoils composed of sandstone have been shown to become more acidic as they weather, however, some have become more acidic and then increased in alkalinity due to continued weathering and release of carbonates (Haering et al., 2004). In this experiment, the gray sandstone did just that, with its most alkaline $\mathrm{pH}$ in year three of the study (Figure 15). The brown sandstone had mixed results. The 1.2-m brown sandstone plot had its most acidic reading in 2007, while the $1.5-\mathrm{m}$ brown sandstone became more alkaline in year two and then more acidic in year three. 
Table 9. Degrees of freedom, sum of squares, $F$ value, and probabilities of select elements at Catenary Coal, Kanawha County, West Virginia.

\begin{tabular}{lcccc}
\hline Element & DF & Type I SS & F value & Pr> F \\
\hline $\mathrm{Al}$ & 5 & 17874.5 & 42.1 & .0004 \\
$\mathrm{Ca}$ & 5 & 51583.7 & 1.9 & .2557 \\
$\mathrm{Fe}$ & 5 & 26990.1 & 4.2 & .0696 \\
$\mathrm{~K}$ & 5 & 1341.2 & 2.9 & .1327 \\
$\mathrm{Mg}$ & 5 & 6340.2 & 1.3 & .4036 \\
$\mathrm{Mn}$ & 5 & 8318.4 & 4.4 & .0644 \\
$\mathrm{P}$ & 5 & 3086.9 & 34.4 & .0007 \\
\hline
\end{tabular}

Table 10. Average values and significant differences for elements analyzed from samples at Catenary Coal, Kanawha County, West Virginia.

\begin{tabular}{lcrcrrr}
\hline & \multicolumn{5}{c}{ Treatments } \\
Element & 5B NC & 5B C & 4B NC & 4B C & 5G NC & 5G C \\
\hline $\mathrm{Al}$ & $113 \mathrm{ab}$ & $91 \mathrm{~b}$ & $128 \mathrm{a}$ & $134 \mathrm{a}$ & $35 \mathrm{c}$ & $44 \mathrm{c}$ \\
$\mathrm{Ca}$ & $438 \mathrm{a}$ & $552 \mathrm{a}$ & $413 \mathrm{a}$ & $412 \mathrm{a}$ & $525 \mathrm{a}$ & $565 \mathrm{a}$ \\
$\mathrm{Fe}$ & $79 \mathrm{~b}$ & $65 \mathrm{~b}$ & $123 \mathrm{ab}$ & $84 \mathrm{~b}$ & $203 \mathrm{a}$ & $146 \mathrm{a}$ \\
$\mathrm{K}$ & $66 \mathrm{ab}$ & $61 \mathrm{~b}$ & $70 \mathrm{ab}$ & $88 \mathrm{a}$ & $55 \mathrm{~b}$ & $60 \mathrm{~b}$ \\
$\mathrm{Mg}$ & $216 \mathrm{a}$ & $255 \mathrm{a}$ & $193 \mathrm{a}$ & $217 \mathrm{a}$ & $185 \mathrm{a}$ & $197 \mathrm{a}$ \\
$\mathrm{Mn}$ & $99 \mathrm{ab}$ & $83 \mathrm{ab}$ & $82 \mathrm{ab}$ & $102 \mathrm{a}$ & $30 \mathrm{c}$ & $49 \mathrm{bc}$ \\
$\mathrm{P}$ & $18 \mathrm{~b}$ & $26 \mathrm{~b}$ & $15 \mathrm{~b}$ & $15 \mathrm{~b}$ & $53 \mathrm{a}$ & $51 \mathrm{a}$ \\
\hline
\end{tabular}


Table 11. 2005 to 2007 soil properties on three soil medium types under two compaction treatments at Catenary's Samples Mine in Kanawha County, West Virginia.

\begin{tabular}{lllllll}
\hline & \multicolumn{5}{c}{ Treatments } \\
Properties & 5B-C & 5B-NC & 4B-C & 4B-NC & 5G-C & 5G-NC \\
\hline pH 2005 & 6.0 & 4.7 & 4.7 & 5.2 & 7.6 & 8.3 \\
pH 2006 & 5.8 & 5.7 & 4.5 & 4.6 & 8.2 & 8.2 \\
pH 2007 & 6.5 & 4.5 & 4.3 & 4.7 & 8.5 & 8.3 \\
Avg. & $6.1 \mathrm{~b}$ & $5.0 \mathrm{bc}$ & $4.5 \mathrm{c}$ & $4.8 \mathrm{c}$ & $8.1 \mathrm{a}$ & $8.2 \mathrm{a}$ \\
\% fines 2005 & 50 & 53 & 49 & 48 & 40 & 36 \\
\% fines 2006 & 43 & 36 & 41 & 37 & 29 & 31 \\
\% fines 2007 & 64 & 60 & 59 & 61 & 34 & 34 \\
Avg. & $53 \mathrm{a}$ & $50 \mathrm{a}$ & $50 \mathrm{a}$ & $49 \mathrm{a}$ & $34 \mathrm{a}$ & $34 \mathrm{a}$ \\
& & & & & & \\
\% sandstone 2005 & 47 & 44 & 48 & 50 & 57 & 61 \\
\% sandstone 2006 & 55 & 61 & 58 & 61 & 67 & 65 \\
\% sandstone 2007 & 36 & 40 & 41 & 40 & 66 & 66 \\
Avg. & $46 \mathrm{a}$ & $49 \mathrm{a}$ & $49 \mathrm{a}$ & $51 \mathrm{a}$ & $64 \mathrm{a}$ & $64 \mathrm{a}$ \\
& & & & & & \\
EC 2005 (dS m $\left.{ }^{-1}\right)$ & .39 & .43 & .53 & .28 & .21 & .20 \\
\hline
\end{tabular}




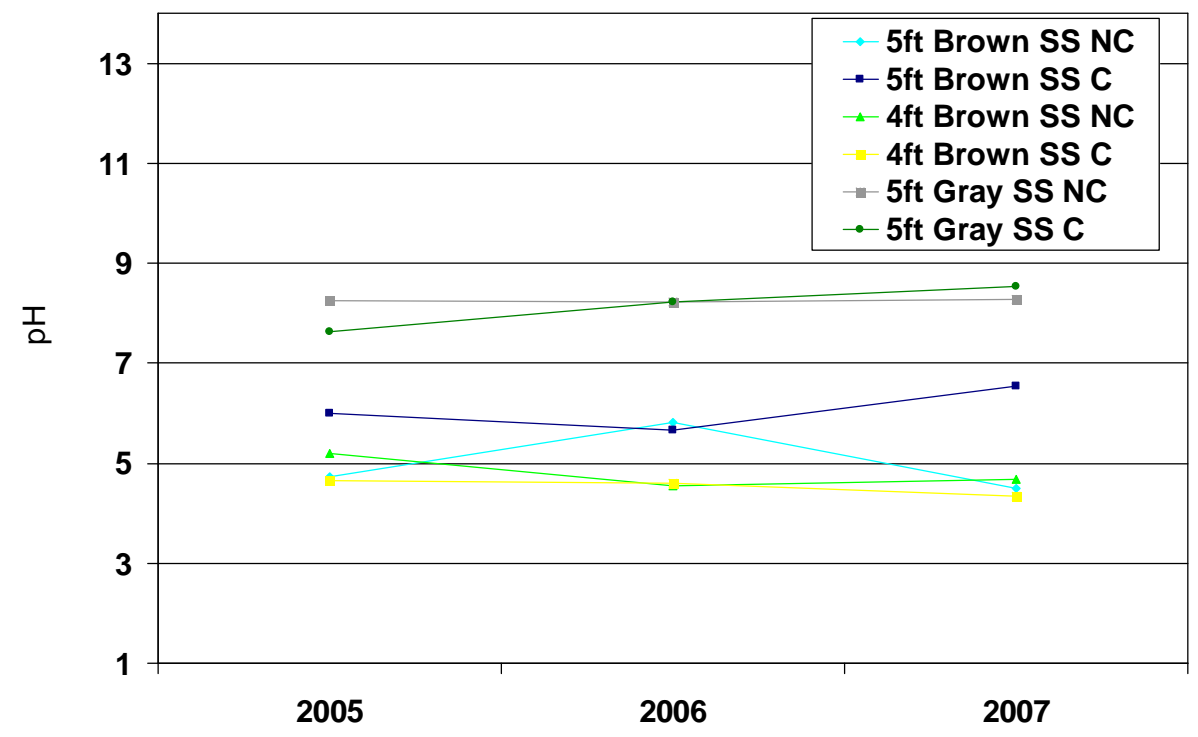

Figure 15. Soil pH across all treatments through three growing seasons at Catenary Coal in Kanawha County, West Virginia.

The changes in percent fines and sandstone had an opposing trend. On all treatments the percent fines decreased from $47 \%$ in year one to $36 \%$ in year two, then it increased to $52 \%$ in year three (Table 11 ). The percent sandstone did the exact opposite on all treatments with the exception of 1.5-m gray sandstone compact and non-compact. On the 1.5-m gray sandstone plot the percent sandstone increased in year two and was similar in year three. None of these changes were large enough to be significant at the $\mathrm{p}<.05$ level. It was expected that the gray sandstone would rapidly breakdown since this was the first time it was exposed to weathering. The initial drop in percent fines in year two showed that this may not happen. However, this decrease could have occurred due to the downward movement of fines through the macro pores and large cracks common in minesoil. 
In year three the percent fines rose slightly, which may indicate that the very porous medium may be slowly building up material in the upper portion of the profile, leading to an increase of percent fines in the sampling region (upper $25 \mathrm{~cm}$ ).

Electrical conductivity has been linked to productivity on minesoils (McFee et al., 1981). EC values greater than $1000-3000 \mu \mathrm{S} / \mathrm{cm}$ are considered detrimental to plant growth (McFee et al., 1981; Rodrigue and Burger, 2004). In our samples, EC values ranged from 200-530 $\mu \mathrm{S} / \mathrm{cm}$, within the range found by Rodrigue and Burger (2004) in western Virginia mines, which ranged from $300-1700 \mu \mathrm{S} / \mathrm{cm}$. In the same study by Rodrigue and Burger (2004), they associated higher EC values with finer textured unoxidized spoils, whereas more coarse textured oxidized materials had lower EC values.

While there was variation of elemental concentrations across treatments, the only significant differences were observed for aluminum, iron, and phosphorus. Phosphorus, as phosphate, is usually not a concern for leaching since soils generally hold phosphate very well. However, if the soil is very sandy or coarse with little clay, aluminum, iron oxides, or organic matter, phosphates can be leached into the ground water (Sparks, 2003). Minesoils, especially ones derived from sandstone with little to no shales, are coarse textured with little organic matter. The data show that phosphorus concentrations decreased from year one to year two across all treatments except 1.5-m brown sandstone non-compact, where it stayed the same through the first two years (Figure 16). From year two to year three, half the treatments (1.2-m brown sandstone compact and non-compact, and 1.5-m brown sandstone non-compact) continued to decrease, while the other three (1.5-m gray sandstone compact and non-compact and 1.5-m brown sandstone compact) increased in phosphorus concentration in year three. 


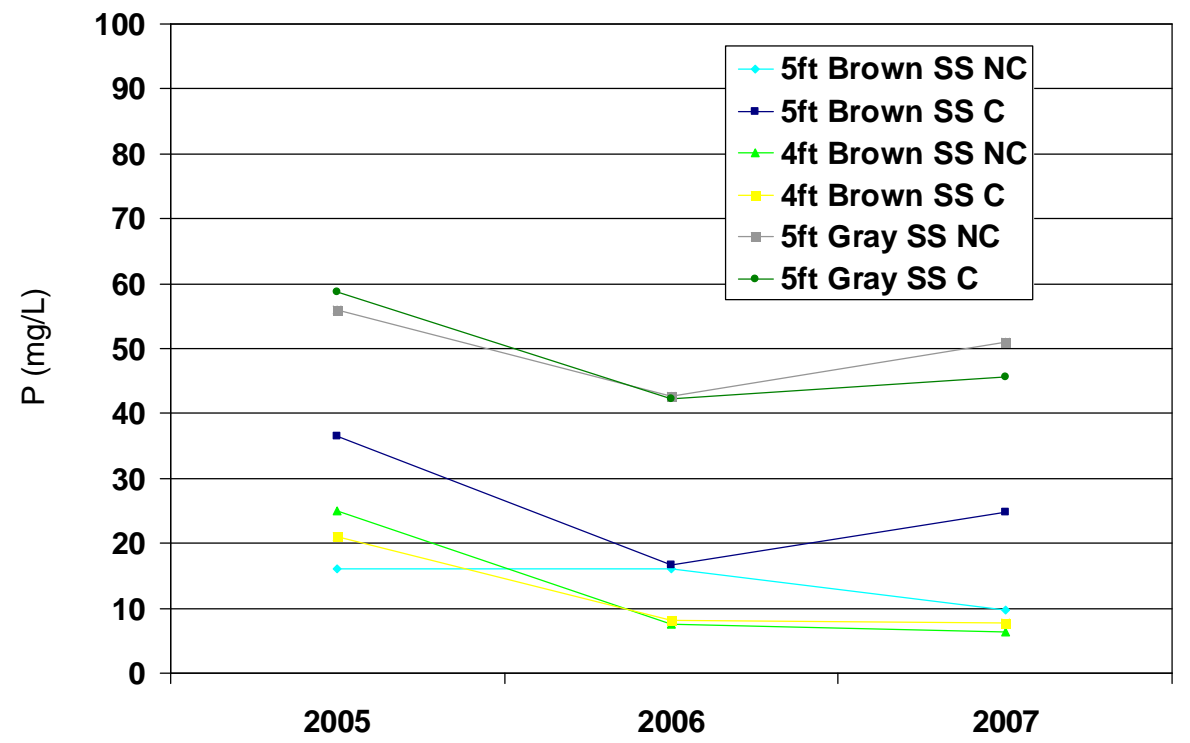

Figure 16. Phosphorus concentration across all treatments during three growing seasons at Catenary Coal, Kanawha County, West Virginia.

Aluminum was significantly different when comparing the different substrate treatments (Figure 17). Aluminum can be particularly toxic to plant roots, especially at low $\mathrm{pH}$ values where the aluminum tends to solubilize (Miller, 1998). In this study, aluminum only varied by substrate, not by year, as phosphorus did. This was surprising in that aluminum is particularly soluble at soil $\mathrm{pH}$ below 5 (brown sandstone) and therefore showed significantly higher aluminum concentrations as compared to the gray sandstone through year two.

Iron was significantly higher on the gray sandstone as compared to brown sandstone. This is somewhat surprising as oxidized materials, like the brown sandstone, generally have more free Fe oxides than its unoxidized, gray sandstone, counterpart (Haering et al., 1993). There were no significant differences in iron concentrations 


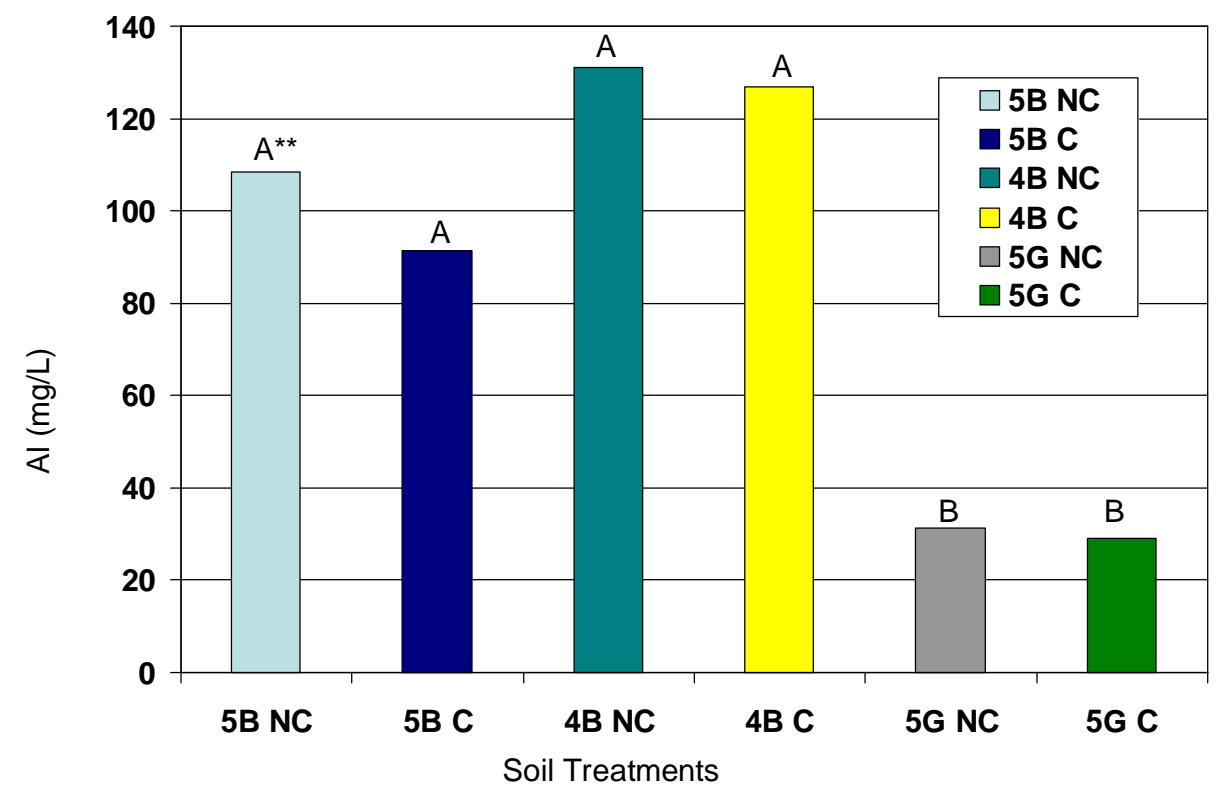

Figure 17. Concentration of $\mathrm{Al}$ across all treatments after three growing seasons at Catenary Coal, Kanawha County, West Virginia. ** Columns with different letters are significantly different at the $p<.05$ level.

among years. However, in a study conducted by Haering et al. (1993), iron

concentrations between unoxidized siltstone and oxidized sandstone were significantly

different for the first three years, but by the fifth year there were no significant

differences between substrates. High iron oxide levels are also considered to be

detrimental to the availability of phosphorus (Howard et al., 1988).

\section{Fertility Experiment}

Comparison of the two extraction methods showed that there were significant differences in three of the four elements examined (Tables 12 and 13). Potassium and phosphorus were significantly higher on the extractor method, while calcium was greater in the shaker method. Magnesium had no significant differences between methods. 
Table 12. Degrees of freedom, sum of squares, $F$ values, and probabilities of four elements analyzed in fertility experiment.

\begin{tabular}{|c|c|c|c|c|}
\hline Category & DF & Type I SS & F Value & $\operatorname{Pr}>\mathrm{F}$ \\
\hline \multicolumn{5}{|c|}{ Extraction Method } \\
\hline $\mathrm{Mg}$ & 1 & 121.4 & 1.8 & .185 \\
\hline $\mathrm{Ca}$ & 1 & 2095.2 & 5.2 & .024 \\
\hline $\mathrm{K}$ & 1 & 1339.6 & 9.8 & .002 \\
\hline $\mathrm{P}$ & 1 & .01 & 48.8 & $<.0001$ \\
\hline \multicolumn{5}{|l|}{ Substrate } \\
\hline $\mathrm{Mg}$ & 2 & 415.9 & 3.1 & .049 \\
\hline $\mathrm{Ca}$ & 2 & 390.6 & 0.5 & .622 \\
\hline $\mathrm{K}$ & 2 & 232.7 & 0.8 & .441 \\
\hline $\mathrm{P}$ & 2 & 0.0 & 4.1 & .018 \\
\hline \multicolumn{5}{|l|}{ Sieve Size } \\
\hline $\mathrm{Mg}$ & 1 & 9.3 & 0.1 & .714 \\
\hline $\mathrm{Ca}$ & 1 & 64.2 & 0.2 & .693 \\
\hline $\mathrm{K}$ & 1 & 0.2 & 0.0 & .973 \\
\hline $\mathrm{P}$ & 1 & .0005 & 1.3 & .253 \\
\hline \multicolumn{5}{|c|}{ Leaching Event } \\
\hline $\mathrm{Mg}$ & 3 & 134414 & 198.1 & $<.0001$ \\
\hline $\mathrm{Ca}$ & 3 & 15234 & 60.2 & $<.0001$ \\
\hline $\mathrm{K}$ & 3 & 28324 & 217.8 & $<.0001$ \\
\hline $\mathrm{P}$ & 3 & 103741 & 54.6 & $<.0001$ \\
\hline
\end{tabular}


Table 13. Average values of $\mathrm{Mg}, \mathrm{Ca}, \mathrm{K}$, and $\mathrm{P}$ from brown and gray sandstone leached by two extraction methods.

\begin{tabular}{ccccc}
\hline & $\mathrm{Mg}$ & $\mathrm{Ca}$ & $\mathrm{K}$ & $\mathrm{P}$ \\
\hline Extraction Method & & & & \\
Shaker & $7.4 \mathrm{a}$ & $18.7 \mathrm{a}$ & $8.1 \mathrm{~b}$ & $.01 \mathrm{~b}$ \\
Extractor & $8.7 \mathrm{a}$ & $13.3 \mathrm{~b}$ & $12.4 \mathrm{a}$ & $.02 \mathrm{a}$ \\
& & & & \\
Substrate & & & & \\
$1.5 \mathrm{~m}$ Brown & 8.3 & 16.7 & 10.5 & .02 \\
$1.2 \mathrm{~m}$ Brown & 8.5 & 17.1 & 11.0 & .02 \\
$1.5 \mathrm{~m}$ Gray & 7.3 & 15.5 & 9.2 & .01 \\
& & & & \\
Sieve Size & & & & \\
80 & 8.1 & 16.2 & 10.4 & .02 \\
270 & 8.0 & 16.0 & 10.1 & .02 \\
& & & & \\
Leaching Events** & & & & \\
1 & 18.8 & 28.6 & 26.5 & .03 \\
2 & 21.8 & 34.8 & 32.2 & .05 \\
3 & 30.8 & 63.1 & 41.0 & .06 \\
4 & 32.2 & 64.0 & 41.0 & .06 \\
\hline
\end{tabular}

**Leaching events are not average values but rather the summation of each nutrient through that leaching event.

One of the main objectives of this study was to compare the brown and gray sandstone. Since brown sandstone had been exposed to weathering and oxidation processes already, it would follow that there should be less available nutrients. However, this was not supported by the data. There were no significant differences for any of the four examined nutrients between the brown and the gray sandstone materials (Tables 12 and 13).

While finer textured materials (not clay size) would be expected to release higher concentrations of elements more quickly than more coarse textured materials, this was 
not evident in the experiment. In fact, materials sieved into these different sized particles showed no difference in elemental concentrations (Tables 12 and 13).

The greatest differences were between leaching events. $\mathrm{Mg}, \mathrm{Ca}$, and $\mathrm{K}$ showed the same trend across all four leaching events. In the first leaching event all elements had their highest concentrations. In the second leaching event they all had their third greatest concentrations, while in the third leaching event they all had their second highest

concentrations, and finally in the last $\left(4^{\text {th }}\right)$ leaching event they all had their lowest concentration (Table 12 and 13 and Figure 18).

\section{Conclusions}

\section{Soil physical and chemical properties:}

In this study, only two of the ten measured variables were significantly different when substrate, compaction, and year were compared at the alpha $=.05$ level. While more significant results were expected, there has not been enough time lapsed for the natural weathering of these plots to make significant differences in the physical and chemical compositions.

\section{Soil Fertility}

Comparison of methods shows that the extractor method leached more $\mathrm{K}$ and $\mathrm{P}$ out of samples than the shaking method. More Ca was leached using the shaking method compared to extractor method. This was the method thought to release more nutrients because the shaking of the samples could have physically broken the materials down more. There were surprisingly no significant differences between substrate (brown vs. gray sandstone), or sandstone or fine particles percent (sieve size). It was expected that 
brown sandstone would release lesser amounts since it had been exposed to leaching and oxidation (more weathered) while the gray sandstone had not (less weathered).

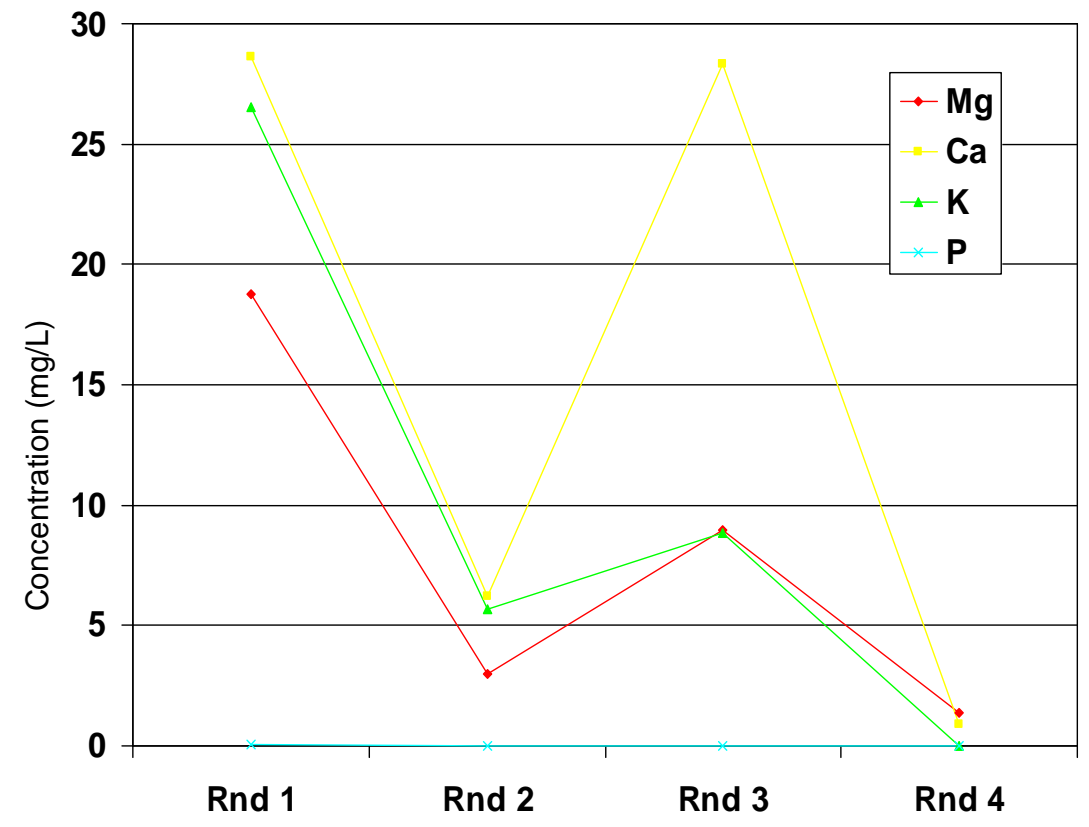

Figure 18. Concentration of $\mathrm{Mg}, \mathrm{Ca}, \mathrm{K}$, and $\mathrm{P}$ over four extraction rounds across both extraction methods. 


\section{Chapter 5. Literature Cited}

Acts of West Virginia Legislature. 1945. Regular Session. 85:345-351. Charleston, WV.

Andrews, J.A., J.E. Johnson, J.L. Torbert, J.A. Burger, and D.L. Kelting. 1998. Minesoil and site properties associated with early height growth of eastern white pine. J. Environ. Qual. 27:192-199.

Ashby, W. C. 1987. Forests. Pages 89-108 in W. R. Jordan, M. E. Gilpin, and J. D. Arber, editors. Restoration ecology. Cambridge University Press, Cambridge, United Kingdom.

Ashby, W.C., 1991. Surface mine tree planting in the midwest pre- and post-public law 95-87. In: Oaks, W., Bowden, J. (Eds.), Technologies for Success. Proceedings of the American Society for Surface Mining and Reclamation, vol. 2, Durango, CO, 14-17 May. American Society for Surface Mining and Reclamation, Lexington, KY.

Ashby, W. C. 1996a. Growth of hardwoods and conifers after 47 years on coal mine soils in southern Illinois. Tree Planters' Notes 47:24-29.

Ashby, W.C. 1996b. Red oak and Black Walnut growth increased with minesoil ripping. International Journal of Mining, Reclamation and Environment. Vol. 10. Iss. 3. 1996. pg 113-116.

Ashby, W.C. 1997. Soil ripping and herbicides enhance tree and shrub restoration on stripmines. Restoration Ecology. 5(2):169-177.

Ashby, W.C., W.G. Vogel, C.A. Kolar and G.R. Philo. 1984. Productivity of stony soils on strip mines. Erosion and productivity of soils containing rock fragments, Soil Science Society of America, Madison, Wisconsin. pp. 31-44.

Ashby, W.C., W.G. Vogel, and N.F. Rogers. 1985. Black locust in the reclamation equation Gen. Tech. Rep. NE-105. Broomall, PA: U. S. Department of Agriculture, Forest Service, Northeastern Forest Experiment Station. 12 p..

Auch, W.E., J.A. Burger, and D.O. Mitchum. 2004. Influences of site factors on the survival and growth of early and late-successional Appalachian hardwoods on a reclaimed surface mined land. In Proceedings of the American Society for Surface Mining and Reclamation, Morgantown, WV. 18-24 April, 2004. American Society for Surface Mining and Reclamation, Lexington, KY. 
Balmer and Williston. 1983. Managing eastern white pine in the southeast. USDA For. Ser. Rep. R8-FR1. 11 pp.

Beck, D.E. and L. Della-Bianca. 1970. Yield of unthinned yellow-poplar. USDA For. Serv. Res. Pap. SE-58, 20 pp.

Boyce, S. 1999. Office of surface mining (OSM) revegetation team survey results. p. 3135. In K. C. Vories and D Throgmorton (ed.) Proceedings of the enhancement of reforestation at surface coal mines: Technical interactive forum. 23-24 Mar. 1999. Fort Mitchell, KY. UDSI, OSM, Coal Research Center at SIU, Texas Utilities.

Bower, C.A., and L.V. Wilcox. Soluble salts. In Methods of soil analysis, part 2. C.A. Black editor. ASA, Madison, WI.

Brenner, F.J., M. Werner, and J. Pike. 1984 Ecosystem development and natural succession in surface coal mine reclamation. Minerals and Environment, 6, 1022.

Brown, J.H. 1962. Success of tree planting on strip-mined areas in West Virginia. 35 pages. West Virginia University agricultural station bulletin 473, Morgantown, WV.

Burger, J.A. 1999. Academic research perspective on experiences, trends, constraints and needs related to reforestation of mined land. p.63-74. In Proc. Enhancement of reforestation at surface mines. Technical interactive forum, Fort Mitchell, KY, 2324 Mar. 1999.

Burger, J.A., and J.L. Torbert. 1990. Mined land reclamation for wood production in the Appalachian region. In Proceedings of the 1990 mining and reclamation conference and exhibition, Vol. 1. (eds J.G. Skousen, J. Sencindiver, and D. Samuel). p. 159-163. West Virginia University, Morgantown, WV.

Burger, J.A., and C.E. Zipper. 2002. How to restore forests on surface mined lands in Virginia. Virginia cooperative extension publication 460-123.

Burger, J. A., D. A. Scott, and D. O. Mitchem. 2002. Field assessment of mine soil quality for establishing hardwoods in the Appalachians. p. 226-240. In: R. Barnhisel and M. Collins (eds.). Reclamation with a Purpose. 19th Ann. Mtg., American Society of Mining and Reclamation, Lexington, KY.

Burger, J.A., D.O. Mitchum, C.E Zipper, and R. Williams. 2005a. Herbaceous ground cover effects on native hardwoods planted on mined lands. In Proceedings of the 2005 American Society for Mining Reclamation Breckenridge, CO, 18-24 June. American Society for Surface Mining and Reclamation, Lexington, KY. 
Burger, J., D. Graves, P. Angel, V. Davis, and C. Zipper. 2005b. Appalachian regional reforestation initiative. Forestry reclamation advisory \#2. The forestry reclamation approach.

Byrnes, W.R., W.W. McFee, and J.G. Stockton. 1980. Properties and plant growth potential of mineland overburden. USDA/EPA interagency energy-environment R \& D program report. CR-10, EPA-600/780-054.

Casselman, C.N., T.R. Fox, J.A. Burger, A.T. Jones, and J.M. Galbraith. 2006. Effects of silvicultural treatments on survival and growth of trees planted on reclaimed mined land in Appalachians. For. Eco. and Management. Vol. 223. Iss. 1-3.pg 403-414.

Chaney W.R., P.E.Pope, and W.R. Byrnes. 1995. Tree survival and growth on land reclaimed in accord with public law 95-87. J. Environ. Quality. 24: 630- 634.

Ciolkosz, E.J., R.C. Cronce, R.L. Cunningham, and G.W. Petersen. 1985. Characteristics, genesis, and classification of Pennsylvania minesoils. Soil Sci. 139:232-238.

Cummins, D.G., W.T. Plass, and C.E. Gentry. 1965. Chemical and physical properties of spoil banks in the eastern Kentucky coal fields. Central States Experiment Station, Columbus, $\mathrm{OH}$.

Daniels, W.L., and C.E. Zipper. 1998. Improving coal surface mine reclamation in the central Appalachian region. p. 139-162. In J.C. Cairns (ed.) Rehabilitating damaged ecosystems. Vol. 1. CRC Press, Boca Raton, FL.

Davidson, W.H., R.J. Hutnik, and D.E. Parr. 1984. Reforestation of mined land in the northeastern and north-central U.S. North. J. Appl. For. 1: 7- 12.

DenUyl, D. 1962. Survival and growth of hardwood plantations on strip mine spoil banks of Indiana. Jour. For. 60: 603-606.

Erhart, P.P. 1984. Midwest reclamation methods combat soil compaction. Coal Min. Process. Vol/Iss: 21:4.

Groninger, J.W., S.D. Fillmore, R.A. Rathfon. 2006. Stand characteristics and productivity potential of Indiana surface mines reclaimed under SMCRA. N. J. of App. For. Vol. 23 Number 2. June 2006. pg. 94-99.

Groninger, J., J. Skousen, P. Angel, C. Barton, J. Burger, and C. Zipper. 2007. Appalachian regional reforestation initiative. Forestry reclamation advisory \#5. Mine reclamation practices to enhance forest development through natural succession. 
Haering, K.C., W.L. Daniels, J.A. Roberts. 1993. Changes in mine soil properties resulting from overburden weathering. J. Environ. Qual.

22:194-200.

Haering, K.C., W.L. Daniels, and J.M. Galbraith. 2004. Appalachian Mine Soil Morphology and properties: Effects of weathering and mining method. Soil Sci. Soc. Am. J. 68:1315-1325.

Harlow, W.M., E.S. Harrar. 1968. Textbook of dendrology. $5^{\text {th }}$ edition. McGraw-Hill. New York.

Hatchell, G.E., C.W. Ralston, and R.R. Foil. 1970. Soil disturbances in logging: effects on soil characteristics and growth of loblolly pine in the Atlantic Coastal Plain. J. For. 68: 772-775.

Hicks, R.R. Jr. 1998. Ecology and management of central hardwood forests. Wiley, New York, USA. 368pp.

Hicks, R.R. Jr. and D.A. Mudrick. 1994. Forest Health, 1993: A status report for West Virginia. West Virginia Department of Agriculture, Charleston, 68pp.

Holl, K.D. 2002. Long-term vegetation recovery on reclaimed coal surface mines in the eastern USA. J. Appl. Ecol. 39:960-970.

Holl, K.D., C.E. Zipper, and J.A. Burger. 2001. Recovery of native plant communities after mining. Powell River Project Series. Virginia Cooperative Extension. Pub. \# 460-140.

Howard, K.M., and M. Newton. 1984. Overtopping by successional coast-range vegetation slows Douglas fir seedlings. J. For. 82. 178-180.

Howard, J.L., D.F. Amos, and W.L. Daniels. 1988. Phosphorus and potassium relationships in southwestern Virginia coal mine spoils. J. Environ. Qual. 17:695700 .

Ike, A.F. Jr. and C.D. Huppuch. 1968. Predicting tree height growth from soil and topographic site factors in the Georgia Blue Ridge Mountains. Georgia For. Res. Pap. 54, 11 pp.

Jurinak, J.J., J. Bowden, F. Samson, and T. Portal. 1987. Electrical Conductivity. p. 27 -34. In R.D. William and G.E. Schuman (ed.) Reclaiming mine soils and overburden in the western United States. Soil Conservation Society of America., Ankeny, IA.

Klock, G.O., R.G. Cline, and D.N. Swanston. 1984. Geology and Soils. p. 65-96. In. K. F. Wenger (ed.) Forestry Handbook. Vol. 2. 
Lancaster, K.F. and W.B. Leak. 1978. A silvicultural guide for White pine in the Northeast. USDA Forest Service. General Technical Report. NE-41.

Ledig, F.T. 1983. The influence of genotype and environment on dry matter distribution in plants. In P. A. Huxley, ed. Plant research and agroforestry. Proc. consultative meeting, Internat. Counc. Res. Agrofor., Nariobi, Kenya. 617 p.

McFee, W.W., W.R. Byrnes, J.G. Stockton. 1981. Characteristics of coal mine overburden important to plant growth. J. Environ. Qual. 10:300-308.

Mehlich, A. 1953. Short test methods used in soil testing division. Department of Agriculture, Raleigh, North Carolina. STDP No. 1-53.

Mickalitis, A.B., and D.B. Kutz. 1949. Experiments and observations on planting areas 'stripped' for coal in Pennsylvania. Pennsylvania Forests and Waters. Vol. 1, N3:62-66, 70 .

Miller, S. 1998. Successful tree planting techniques for drastically disturbed lands: A case study of the propagation and planting of container-grown oak and nut trees in Missouri. p. 151-163 In Proc., Mining-gateway to the future, St. Louis, MO. Throgmorton, D., J. Nawrot, J. Mead, J. Galetovic, and W. Joseph (eds.). American Society of Surface Mining and Reclamation, Lexington, KY.

Morgan, M.F. 1941. Chemical soil diagnosis by the universal soil testing system. Conn. State Agric. Exp. Stn. Bull. 450, 579-628.

Mortland, M.M., Kemper, W.D. 1965. Specific surface. p.532-544. In Methods of soil analysis part 1. (C. Black ed). ASA. Madison, Wisconsin.

Norby, R.J. and E.G. O’Neill. 1991. Leaf area compensating nutrient interactions in $\mathrm{CO}^{2}$-enriched seedlings of Yellow Poplar (Liriodendron tulipifera L) New Phytol. 117. 515-528.

Omi, S.K. 1986. Soil compaction: Effects on seedling growth. USDA Forest Service GTR RM-125.

Pedersen, T.A., A.S. Rogowski, and R. Pennock, Jr. 1980. Physical characteristics of some minesoils. Soil Sci. Soc. Am. J. 44:321-328.

Phillips, M. 2006. Procedures to insure reclamation success. In Proceedings of the American Society for Surface Mining and Reclamation Land Reclamation Symposium. Billings, MT. 4-8 June. American Society for Surface Mining and Reclamation, Lexington, KY. 
Plass, W.T., and J. L. Powell. 1988. Trees and shrubs. p. 176-198. In L. R. Hossner (ed.) Reclamation of Surface Mined Lands. Vol 2. CRC Press, Boca Raton, Fl.

Potter, H.S., S. Weitzman, and G.R. Trimble Jr. 1955. Reforestation of stripped-mined lands. West Virginia Agric. and Forestry Experiment Stat. Mimeographed Circular 55. West Virginia University, Morgantown, WV.

Roberts, J.A., W.L. Daniels, J.C. Bell, and J.A. Burger. 1988. Early stages of mine soil genesis in a Southwest Virginia spoil lithosequence. Soil Sci. Soc. Am. J. 52:716723.

Rodrigue, J.A. and J.A. Burger. 2004. Forest Soil productivity of mined land in the Midwestern and Eastern coalfield regions. Soil Sci. Soc. Am. J. 68:833-844.

Schlesinger, R.C. 1990. Fraxinus Americana L., white ash. In: Silvics of North America, Vol. 2, Hardwoods, R.M. Burns and B.H. Honkala (eds.) USDA For. Serv. Agric. Handb. 654:333-338.

Sencindiver, J.C., and J.T. Ammons. 2000. Minesoil genesis and classification. p. 595614. In R.I. Barnhisel et al. (ed.) Reclamation of drastically disturbed lands. Agron. Monogr. No. 41. ASA, CSSA, and SSSA, Madison, WI.

Siegel-Issem, C.M., J.A. Burger, R.F. Powers, F. Ponder, and S.C. Patterson. 2005. Seedling root growth as a function of soil density and water content. Soil Sci. Soc. Am. J. 69:215-226.

Skousen, J.G., C.D. Johnson, and K. Garbutt. 1994. Natural revegetation of 15 abandoned mine land sites in West Virginia. J. Environ. Qual. 23:1224-1230.

Skousen, J.G., P. Ziemkiewicz and C. Venable. 2006. Tree recruitment and growth on 20-year-old, unreclaimed surface mined lands in West Virginia. International Journal of Mining, Reclamation and Environment. Vol. 20, No. 2, June 2006, 142 -154 .

Sobek, A.A., J.G. Skousen, and S.E. Fisher, Jr. 2000. Chemical and physical properties of overburdens and minessoils. P. 77-104. In R.I. Barnhisel et al. (ed.) Reclamation of drastically disturbed lands. Agronomy 41. ASA, CSSA, SSSA, Madison WI.

Starnes, L.B. and D.C. Gasper. 1995. Effects of surface mining in aquatic resources in North American fisheries. Fisheries. Vol.20. Iss. 5. pg. 20-23.

Sparks, D.L. 2003. Environmental soil chemistry. $2^{\text {nd }}$ Edition. Academic press. San Diego, CA. 
Sweigard, R., J. Burger, C. Zipper, J. Skousen, C. Barton, and P. Angel. 2007. Appalachian regional reforestation initiative. Forestry reclamation advisory \#3. Low compaction grading to enhance reforestation success of coal surface mines.

Thurman, N.C., and J.C. Sencindiver. 1986. Properties, classification, and interpretations of minesoils at two sites in West Virginia. Soil Sci. Soc. Am. J. 50:181-185.

Tiaz, L., and E. Zeiger. 1991. Stress physiology. In Plant physiology. p. 362-364. Benjamin/Cummings Publ. Co., CA.

Torbert, J.L. 1995. Reclamation of surface-mined forestland in the southern Appalachians. Ph.D. Dissertation, Virginia Polytechnical Institute and State University, Blacksburg, VA.

Torbert, J.L., J.A. Burger, J.N. Lien and S.H. Schoenholtz.1985. Results of a tree species trial on a recontoured surface mine in southwestern Virginia. Southern Journal of Applied Forestry, 9, 150-153.

Torbert, J.L., A.R. Tuladhar, J.A. Burger, and J.C. Bell. 1988. Minesoil property effects on the height of 10-year-old white pine. J. Environ. Qual. 17:189-192.

Torbert J.L., J.A. Burger and W.L. Daniels. 1990. Pine growth variation associated with overburden rock type on a reclaimed surface mine in Virginia. J. Environ. Qual. 19 (1990), pp. 88-92.

Torbert, J.L., J.A. Burger, S.H. Schoenholtz, and R.E. Kreh. 2000. Growth of three pine species after eleven years on reclaimed mine soils in Virginia. North J. Appl. For. 17(3):95-99.

Torbert, J.L., and J.A. Burger. 2000. Forest land reclamation. p. 371-398. In Reclamation of drastically disturbed lands. (eds R.I. Barnhisel, R.G. Darmody, and W.L. Daniels). American Society of Agronomy, Madison, WI.

Tyner, E.H., R.M. Smith, and S.L. Galpin. 1948. Reclamation of strip-mined areas in West Virginia. J. of the Am. Soc. of Agron. Vol. 40, No. 4. Pg. 313-323.

Vogel, W.G. 1981. A guide for revegetating coal minsoils in the Eastern United States. USDA For. Serv. Gen. Tech. Rep. NE-68. Broomall, PA.

Wendel, G.W. and H.C. Smith. 1990. Easter White pine. In Burns, R.M., and B.H. Honkala (tech. cords). Silvics of North America: 1. Conifers. Agriculture Handbook 654. U.S. Dept. of Agriculture., Forest Service, Washington, DC. Vol. 2, p. 877 
West Virginia Office of Miners' Health, Safety and Training. "West Virginia Coal Facts." June 16, 2007. West Virginia Office of Miners' Health, Safety and Training. October 18, 2007. http://www.wvminesafety.org/wvcoalfacts.htm.

Wood, C.W., and D.E. Pettry. 1989. Initial pedogenic progression in a drastically disturbed prime farmland soil. Soil Sci. Soc. Am. J. 147: 196-207.

Zeleznik, J.D. and J.G. Skousen. 1996. Survival of three tree species on old reclaimed surface mines in Ohio. J. Environ. Qual. Vol. 25, no. 6, pp. 1429-1435. 